\title{
Did the Basel Process of capital regulation enhance the resiliency of European banks? ${ }^{\text {in }}$
}

\author{
Thomas Gehrig $^{\mathrm{a}, \mathrm{b}, *}$, Maria Chiara Iannino ${ }^{\mathrm{c}}$

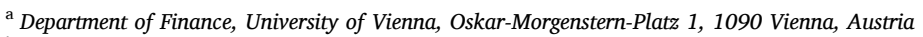 \\ ${ }^{\mathrm{b}}$ CEPR, ECGI and VGSF \\ ${ }^{\text {c }}$ University of St. Andrews, School of Economics and Finance, Castlecliffe, The Scores, St. Andrews, Fife KY16 9AR, UK
}

\section{A R T I C L E I N F O}

\section{JEL classification:}

B26

E58

G21

G28

$\mathrm{H} 12$

$\mathrm{N} 24$

Keywords:

Bank capital

Systemic risk

Internal risk-based models

Contagion

Resilience

Regulation

\begin{abstract}
A B S T R A C T
This paper analyses the evolution of the safety and soundness of the European banking sector during the various stages of the Basel process of capital regulation. We document the evolution of various measures of systemic risk as the Basel process unfolds. Most strikingly we find that the exposure to systemic risk as measured by SRISK has been steeply rising for the highest quintile, moderately rising for the second quintile, and remaining roughly stationary for the remaining three quintiles of listed European banks. This observation suggests that during the Basel process, systemic risk has been contained for the majority of European banks, but not for the largest and riskiest institutions. When analyzing the sources of systemic risk we find compelling evidence that the increase in exposure to systemic risk (SRISK) is tied to the implementation of internal models for determining credit risk, as well as market risk. Based on this evidence, the sub-prime crisis found especially the largest and more systemic banks ill-prepared and lacking resiliency. This condition has been aggravated during the European sovereign crisis. The Banking Union has not restored aggregate resiliency to pre-crisis levels. Finally, low-interest rates considerably affect the contribution to systemic risk, particularly for the riskier banks.
\end{abstract}

\section{Introduction}

This paper has two main contributions: Firstly, it is the first paper that traces the long-run evolution of risk measures of banks and financial institutions over the whole period of operation of the Basel process of capital regulation, both for systemic as well as for individual risk. The paper focuses on the cross-section of European listed banks from the beginning of the Basel process in 1988. The second contribution relates the various risk measures to the underlying economic mechanisms. How is the evolution of the various risk trajectories related to the regulatory process itself? How is it related to other developments in international banking markets? In particular, how do these relations vary across the

\footnotetext{
Without implicating them we are most grateful for the helpful comments of Stefania Albanesi, Martin Brown, Charles Calomiris, Giacomo Calzolari, Jon Dan-

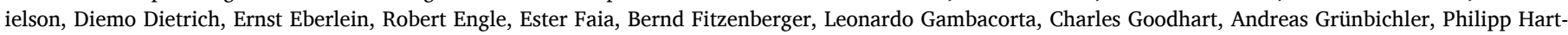

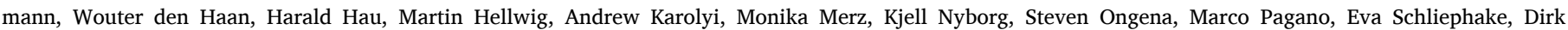

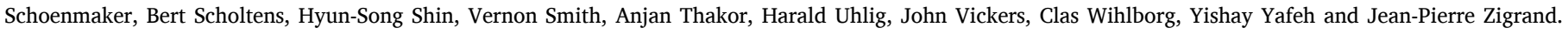

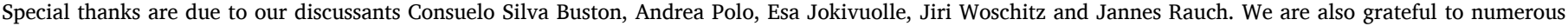

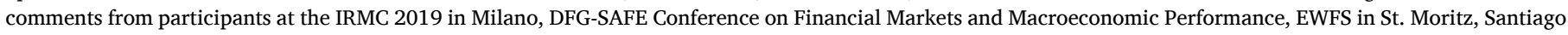

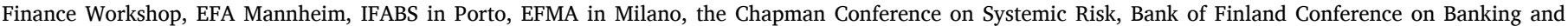

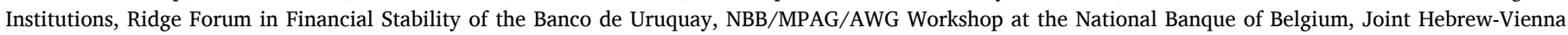

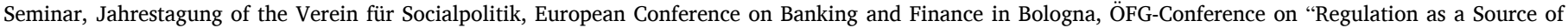

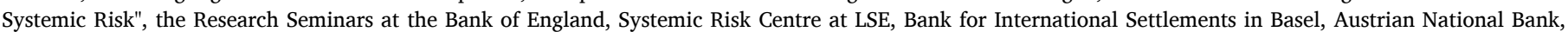

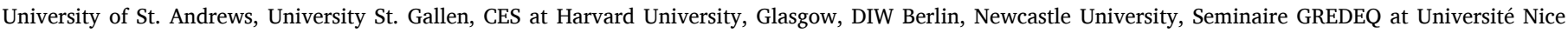

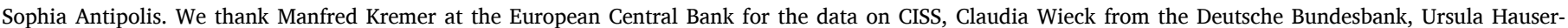

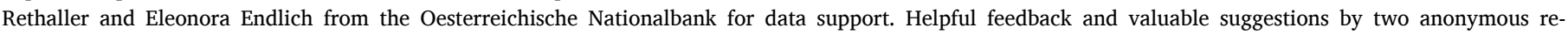
viewers and the editor, Iftekar Hasan, are gratefully acknowledged. Any errors remain our own

* Corresponding author at: Department of Finance, University of Vienna, Oskar-Morgenstern-Platz 1, 1090 Vienna, Austria.

E-mail addresses: thomas.gehrig@univie.ac.at (T. Gehrig), mci@st-andrews.ac.uk (M.C. Iannino).
} 
cross-section of banks? Did, and if so, in which sense did this process enhance the resiliency of banks?

These issues are of crucial importance for evaluating and reforming the Basel process. Since right from the start in 1988, it has always been the intention of the Basel Committee to increase the safety and soundness of banks and the global banking system, while at the same time maintaining a level playing field in an increasingly globalized banking industry (Basel Committee on Banking Supervision, 1988). ${ }^{1}$ The Basel process has been one of continued reform of the original minimum capital standard that affected both, the definition of capital and the risk weights of different asset categories. Most notably, the market risk amendment of 1996 and the reform package Basel II (2006) successively introduced choices between statutory risk weights or risk weights based on institutions' own calculations with the help of internal models. The experience of the Great Financial Crisis certainly suggests that the original goals might not have been reached; immediate regulatory reform was required after the Lehman insolvency, which triggered a new phase of the process now commonly referred to as 'Basel III'. Our analysis provides insights into which aspects of regulatory reform may still require particular attention and scrutiny.

If the intentions of the Basel process of capital regulation had been achieved, one might have expected a general decline in measures of individual as well as systemic risk over the past 30 years, reflecting an increase in bank resiliency. However, we find differently. By tracing SRISK, a systemic risk measure developed by Brownlees and Engle (2017)), we observe a secular increase in the average expected capital shortfall in the European countries from below 5\% of country GDP to about $20 \%{ }^{2}$ We adopt a quantile approach, and in our findings, we see that this increase is mainly driven by the build-up of capital shortfall in the highest quintile of the distribution of banks, while the lowest three quintiles are only weakly increasing capital shortfall.

Based on initial descriptive analyses, other measures of systemic risk also do not readily support the view that banking regulation in the longrun has increased the stability and soundness of the banking system at large. One might argue that general economic risk factors have increased tremendously in intensity and, hence, resiliency would have been much lower in the absence of any Basel regulation. However measures of individual risk, such as the Z-score, show an increase in individual solvency, including an increase in the distance-to-default in the most systemically relevant part of the distribution, implying that at large individual risk factors seem to have been taken into account. Hence, a structural approach is needed to control for the quantitative contribution of economic risk factors and to identify the various drivers of systemic as well as individual bank risk.

Our multivariate analysis of systemic and individual bank risk measures builds on unconditional quantile regressions in order to take into account the cross-distributional heterogeneity and the evolution of bank characteristics as well as market variables. Since our risk measures are based on market valuations, we consider the standard drivers of bank stock prices as controls. In addition, we control for market stress, macroeconomic conditions and monetary policy.

We observe that the implementation of market as well as credit risk models along Basel II regulation have a strong non-linear relationship with the individual bank systemic risk exposures as measured by SRISK.

\footnotetext{
${ }^{1}$ In its 1988 Report, the Basel Committee on Banking Supervision explicitly states: "Two fundamental objectives lie at the heart of the Committee's work on regulatory convergence. These are, firstly, that the new framework should serve to strengthen the soundness and stability of the international banking system; and secondly that the framework should be in [sic!] fair and have a high degree of consistency in its application to banks in different countries with a view to diminishing an existing source of competitive inequality among international banks." (Basel Committee on Banking Supervision, 1988)

2 At the height of the Great Financial Crisis capital shortfall peaked in December 2008 close to $30 \%$ of GDP of an average European country.
}

With the Basel amendment in 1996, banks were allowed to implement internal models to measure their market risk and estimate market-risk weighted assets. We observe, since the introduction of market risk models, a reduction in systemic risk exposures for the lower risk quantiles of banks, but, paradoxically, an increase at the upper quantile of the distribution. Along the same line, Basel II in 2006 introduced the option of using internal models to estimate credit risk and credit-risk weighted assets. We see that also internal models for credit risk tend to be asymmetrically related to banks' exposures. Overall, the introduction of self-regulatory options to calculate risk-based capital on credit exposures tends to be a large source of systemic risk exposure during and after the crisis.

To dig even deeper, we study the effect of credit risk internal models with bank-level implementation data, where we observe a strong aggravating impact on SRISK from the implementation of advanced internal models. Exercising the option of determining most parameters for the quantification of credit risk by means of internal models (advanced approach) contributes to systemic risk across all risk classes, but with the largest impact on the most risky banks. We perform various robustness checks and our results are strongly consistent. They are particularly robust in a difference-in-differences approach carried out on the sample of banks implementing advanced IRBA models after Basel II, versus a sample of control banks matched by propensity score matching.

The paper proceeds as follows: Section 2 describes the Basel process and relates our work to the literature. Section 3 introduces the data and methodology and presents the main descriptive results for the systemic as well as the individual bank risk measures. The multivariate analysis is provided in Section 4. A difference-in-differences analysis is presented in Section 5 before Section 6 concludes.

\section{The Basel process of capital regulation}

\subsection{History}

The Basel process of capital regulation was triggered in late 1974. The first meeting of the Basel Committee on Banking Regulations and Supervisory Practices took place in February 1975. After a long period of consultations, ${ }^{3}$ the first Basel Capital Accord (Basel I) was approved by the G10 governors in December 1987 and publicly announced in July 1988. The Accord was formally implemented in December 1992.

The Accord had already been amended in 1991, to reform the treatment of loan loss reserves, and later repeatedly in 1995 and 1996. The most important amendment was the introduction of internal models under supervisory review as an alternative to statutory rules in January 1996 as part of the Market Risk Amendment (Basel Committee on Banking Supervision, 1996). This amendment essentially provided a choice between a self-regulatory option under supervisory review and statutory regulation. It was designed to provide incentives to improve in-house risk management models, which were highly deficient in the $1990 \mathrm{~s}$ even in multinational banks (see Wuffli, 1995). However, the amendment also implicitly provided incentives to employ internal models as an instrument to reduce regulatory burdens and capital charges, and, hence, to reduce resiliency (see Hellwig, 1995).

Proposals for a new capital accord were triggered by the initiation of a consultation process on a Revised Capital Framework in June 1999. This became the basis of the three-pillar framework of Basel II, which formally culminated in June 2006 in the agreement on Basel II: "International convergence of capital measurement and capital standards: a

\footnotetext{
${ }^{3}$ See Goodhart (2011) for details on the early years of the Basel Committee on Banking Supervision.
} 
revised framework for comprehensive supervision".

Basel II was adopted in most countries with the notable exception of the U.S., one of its strongest original supporters. However, the impact of its implementation could not be properly assessed ${ }^{4}$ since already in 2007 the subprime crises developed into a worldwide crisis and depression. Hence, already in September 2008, the Basel Committee was forced to reconsider its regulatory framework with its guidelines on Principles for Sound Liquidity Risk Management and Supervision triggering the discussion on reforming Basel II, a process now commonly referred to as 'Basel III'.

In November 2017, Basel III was finally concluded after long negotiations. A major stumbling block of the Basel III negotiations was the role of internal models. While the U.S. initially insisted on completely phasing out internal credit risk models, the large European countries, and especially Germany and France, insisted on maintaining them while agreeing on curbing their effectiveness. The final agreement reduces the impact of internal models by a so-called 'output' floor, that limits the amount of reduction of risk weights with internal models to $72.5 \%$ relative to the standard approach. Obviously this long-standing debate about capping internal models reflects deep political disagreement about the contribution of internal models to bank stability and competitiveness.

In light of the regulatory process one would expect a continuous improvement of resiliency measures, both in terms of individual banking risk as well as with respect to systemic risk and across the whole crosssection of banks. After all, the Basel Accord aimed at increasing the safety and soundness of the banking industry right form the start.

With hindsight, Freixas et al. (2015)) argue that the Great Financial Crisis of 2007/8 revealed an insufficient treatment of systemic risk in Basel II regulation, focusing mainly on micro-prudential and neglecting macro-prudential concerns. Accordingly, Basel III reform is far more concentrated on macro-prudential supervision designed to enhance systemic resiliency. According to this perspective, systemic risk measures should be particularly responsive to the Basel III reforms.

Overall we would expect that the regulatory process enhances resiliency measures precisely for those banks that are exposed to risk at most.

\subsection{Literature}

To the best of our knowledge, our work is the first systematic longrun evaluation of the effect of the Basel process of capital regulation on the safety and soundness of banking systems.

While the research papers discussed below opt for partial approaches focusing on specific sets of policy instruments, we take a holistic crosscountry perspective to a larger set of regulatory instruments. This allows us to both measure the combined effect of all policy measures and to assess the relative contribution of different instruments to the resiliency of banks. Moreover, by taking a quantile approach, we can assess the implications of different regulatory instruments on different risk groups. And finally, by relying on market data, our approach incorporates market views and market trust, which is complementary to information incorporated in book values and supervisory data, on which most of the partial approaches rely.

The only paper, we are aware of, taking a similarly comprehensive view of the Basel process in the early stages, now dubbed Basel I, is Wagster (1996)). His focus is on the political economy of implementing capital regulation and its consequences on the valuation of Japanese banks. He finds that the early Basel process can be viewed as a political

\footnotetext{
${ }^{4}$ Given the length of the consultancy process for Basel II, it is quite likely that the process did affect bank business models already well before the official implementation date. Moreover, the self-regulatory pillar allowing internal models was available to officially and fully compliantly drive bank business models since 1996 .
}

bargaining process between national regulators. Many agreements by Japanese authorities, in particular concerning the regulatory treatment of hidden reserves, were elicited by concessions to the Japanese banking sector that were subsequently capitalized in market prices and can be measured accordingly. However, he did not assess the implications of that process on banking stability.

The option of Basel II, allowing banks a high degree of discretion in determining their own risk weights for their loan portfolio subject to supervisory review, generated intensive debate well before the implementation of Basel II. Notably, Danielson et al. (2001)) raised serious concerns about the endogeneity of risks not being addressed at all within the Basel II framework. ${ }^{5}$ The authors warn emphatically that Basel II might not work at all, and unintentionally and paradoxically even reduce safety and soundness of the banking system. ${ }^{6}$ Interestingly, at the same time, leading researchers at the BIS explicitly mention procyclical amplification as a challenge to Basel II and argue in favor of counter-cyclical capital buffers (Borio et al., 2001) and a more macro-prudential approach (Crockett, 2000), central features of the Basel III reform, well before the implementation of Basel II.

Indeed, important concerns raised prior to the implementation of Basel II were found justified ex-post in empirical work. In a crosscountry sample of 21 OECD countries, Mariathasan and Merrouche (2014) find convincing time-series evidence that banks that were given supervisory permission to adopt internal models attempting to strategically manipulate risk weights. This effect is particularly strong for weakly capitalized banks in countries with weaker supervision. However, since the authors concentrate on the adopting banks only, they cannot assess the quantitative impact of the IRB approach relative to the standard approach.

In a quasi-experimental research design, Behn et al. (2016a) document a strong pro-cyclical amplification affect of model-based capital regulation on bank lending in a sample of German banks relative to statutory regulation, as predicted by Danielson et al. (2001). ${ }^{7}$ Behn et al. (2016b) focus again on a large sample of German banks and find that risk weights based on the model-based approach underestimate actual default rates by. 5 to $1 \%$ points. Accordingly, risk weights under the model-based are not commensurate with true underlying economic risk, which is reflected in higher risk premia charged by the banks on those loans.

Our work extends the research of Behn et al. (2016a, 2016b) to European banks, and that of Mariathasan and Merrouche (2014) to the full cross-section of (listed) European banks. We largely confirm and extend the prior findings and place them in perspective across the full cross-section of adopting and non-adopting banks. Moreover, while the above-cited contributions focus mainly on the effect of IRBA implementation on systematic credit risk, we focus on the systemic implications of the longer Basel process. Our study places in perspective the contribution of Basel II regulation to systemic risk relative to other instruments of the process of capital regulation (e.g. internal models for market risk under Basel I) since the early days of the Basel process. In addiction, we run quantile regressions, therefore we can drawn insights on the full distributions of European-listed banks.

After the experience of the Great Financial Crisis, various suggestions have been made to correct the short-comings of Basel II. One suggestion to correct for potentially undue competitive advantages of systemic banks applying internal models is the bucket approach developed by the

\footnotetext{
${ }^{5}$ On the problem of neglecting the endogeneity of systemic risk see also Hellwig (2010)).

${ }^{6}$ For an earlier critique of the model-based approach to incorporate market risk see Gehrig (1995),(1996) and Hellwig (2009). Moreover, early literature by Kahane (1977), Koehn and Santomero (1980), Kim and Santomero (1988) and Rochet (1992) establishes that risk-based capital standards may increase bank failure risk if risk weights are not optimally chosen.

7 See also Repullo and Suarez (2012) for a theoretical model on the procyclicality of capital regulation.
} 
BCBS (Basel Committee on Banking Supervision, 2014). ${ }^{8}$ Taking into account size, interconnectedness, substitutability and complexity, an index of systemic importance is developed and, accordingly, capital charges can be levied in five steps ${ }^{9}$ in order to enhance resiliency of the most systemically important institutions. Our analysis confirms that those banks that were allocated to one of these buckets at least once indeed exhibit significantly higher level of SRISK than average banks. Moreover, we find that, in line with regulatory intentions, the imposition of the extra buffer did contribute to reducing the capital shortfall.

Closest to our work is Bostandzic and Weiss (2018), who compare systemic risk exposures of banks across the Atlantic. On the basis of data 1991-2014, they find that European banks on average are more exposed to systemic risk, as measured by SRISK, than US-banks. They explain the difference in risk exposure by the lower average quality of the loan portfolios of European banks. However, by focusing on the mean exposures, they ignore the substantial cross-sectional heterogeneity in SRISK exposures, which is the focus of our work. ${ }^{10}$

While not at the core of our work, we find results relevant for monetary policy complementing related work. Colletaz et al. (2018) document a general build-up in systemic risk-taking in Europe due to the monetary policy of the ECB. They show that aggregate SRISK is induced by monetary policy. By applying a quantile approach, we find a quite more nuanced picture: while smaller banks tend to reduce capital shortfall with lower short-term interest rates, larger banks actually increase risk-exposures. Moreover, we find that the asset purchase program does not seem to be related to capital shortfall (SRISK) in the lower quartiles, while correlations are positive and significant for the highest quartile. Asset purchases, on the other hand, are related to a reduction in capital shortfall for the lower quartiles only, but not at the upper end of systemically important banks.

\section{Measures of bank resiliency}

This section reports details on the data and the construction of the sample. We then define the main measures of systemic and individual risk used in the analysis, before presenting the most striking descriptive findings.

\subsection{Data and sample}

In order to assess the implementation of the Basel principles, we conduct an empirical investigation on a sample of European financial institutions from 1987 to 2018. Overall, we estimate systemic risk, as well as individual banking risk, for 1117 banking institutions from the Euro-area, Switzerland, and the United Kingdom. ${ }^{11}$ Among all listed financial institutions covered by Compustat Global (GICS codes 40 and 60), we selected all commercial banks and diversified banking institutions (GICS codes 4010 and 4020, respectively). We obtain daily market data (prices and capitalization), keeping only ordinary common shares and excluding secondary listings, and lagged quarterly balance sheet data (book values of equity, total assets and liabilities, and ROA). ${ }^{12}$ All data are converted to US dollars. ${ }^{13}$ Moreover, in the estimation of the

\footnotetext{
8 See Benoit et al. (2019) for a description of this approach

${ }^{9}$ Buckets 1-5 range from 1\%, 1.5\%, 2\%, 2.5\%, 3.5\% respectively

10 There are also slight differences in the sample used and in the calculation of SRISK. While we follow the parametrization suggested by Engle et al. (2015), those authors differentiate between banks with high and low level of gross derivatives (p.21).

11 In details, we include institutions from Austria, Belgium, Switzerland, Cyprus, Germany, Spain, Finland, France, United Kingdom, Greece, Ireland, Island, Italy, Luxembourg, Malta, Netherlands, and Portugal.

12 As the quarterly data go back to 1996, we complete the information back to 1987 with annual balance sheet data.

${ }^{13}$ Since our data start as early as 1988, well before the introduction of the Euro, we prefer to translate all currencies into US dollars.
}

risk measures, we use the MSCI Europe index as the broad market return (Datastream data), and the yield on German federal bonds (Bundesbank data) as the risk-free rate. The next sub-Section 3.2 reports descriptive statistics from this sample of 1117 distinct institutions from the Euroarea, Switzerland, and the United Kingdom. ${ }^{14}$

Later in the paper, the inference analysis is performed on a sub-group of this sample, where bank-level information on IRBA models is available through the SNL database. With Basel II, banks were allowed, past regulatory approval, to use in-house internal models to quantify credit risks of their loan portfolios. Next to following the coarse regulatory categories of risk weighting (Standardized approach), banks have the option to develop their own so-called internal models and estimate the probability of default of loans only (Foundation approach), or, additionally, also the exposure-at-default and the loss-given-default to quantify their credit risk-weighted assets (Advanced approach). SNL provides bank-level quarterly information on the implementation of these internal models for credit risk (IRBA) from 2006, distinguishing three categories: (i) Standardized IRB approach, (ii) Foundation IRB approach, (iii) Mixed IRB Approach, and (iv) Advanced IRB approach. We checked this information with proprietary approval dates of internal models from the Bundesbank, the Österreichische Nationalbank and the Bank of England. Section 4 reports the inference analysis based on this sub-sample, comprising of 99 banking institutions (see Table 8 in the Appendix) from the above countries (excluding Cyprus for data availability).

Finally, we use several control variables in the regressions. We obtained the market stress indicator CISS from the authors (Hollo et al., 2012), and we collected macro variables from OECD (unemployment rate, GDP, and PPI). Further information on the control variables used is reported in Section 4 and in Tables 4 in the Appendix. We also report in the Appendix information on the correlation matrix of the main variables of interest (Table 5), the summary statistics by Basel periods (Table 6) and IRBA categories (Table 7).

\subsection{Measures of bank resiliency}

The resiliency of banks can be measured on the level of an individual bank as well as on a systemic level with the interaction of all banks. This separation accords well with the distinction between micro-prudential and macro-prudential regulation. ${ }^{15}$ While the former aims at increasing bank resiliency by reducing individual banks' failure risk, the latter aims at reducing systemic spill-overs or amplifications at the industry level.

We start by presenting the trajectories of systemic risk measures before contrasting them with measures of individual banking risk, since they have become the main focus of current regulation and supervision. We start with the capital shortfall measure SRISK developed by Brownlees and Engle (2017), which measures a bank's exposure to systemic risk. Next, we present the trajectories of the contribution measure $\Delta$ CoVaR of Adrian and Brunnermeier (2016). ${ }^{16}$ While arguably

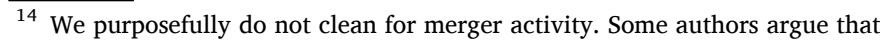
systemic risk increased in conjunction with merger activities (Wagner, 2010). As the scope of our paper is to investigate the overall stress to the market, we do not see appropriate to remove episodes of increasing systemic risk. In robustness checks, we include the annual number of mergers and acquisitions as a regressor to capture this impact (see Table 11).

${ }^{15}$ These terms were developed well in the discussions about Basel II (Borio et al., 2001; Crockett, 2000). Macro-prudential concerns became dominant in post-crisis reforms (see Freixas et al., 2015)).

16 The literature (see especially Giglio et al., 2016) provides a multitude of alternative systemic measures aggregating different information according to different underlying economic mechanisms. For example, the literature review of Benoit et al. (2017) classifies systemic risk according to three different economic mechanisms: systemic risk-taking, contagion and amplification of shocks, each giving rise to different measurement issues.
} 


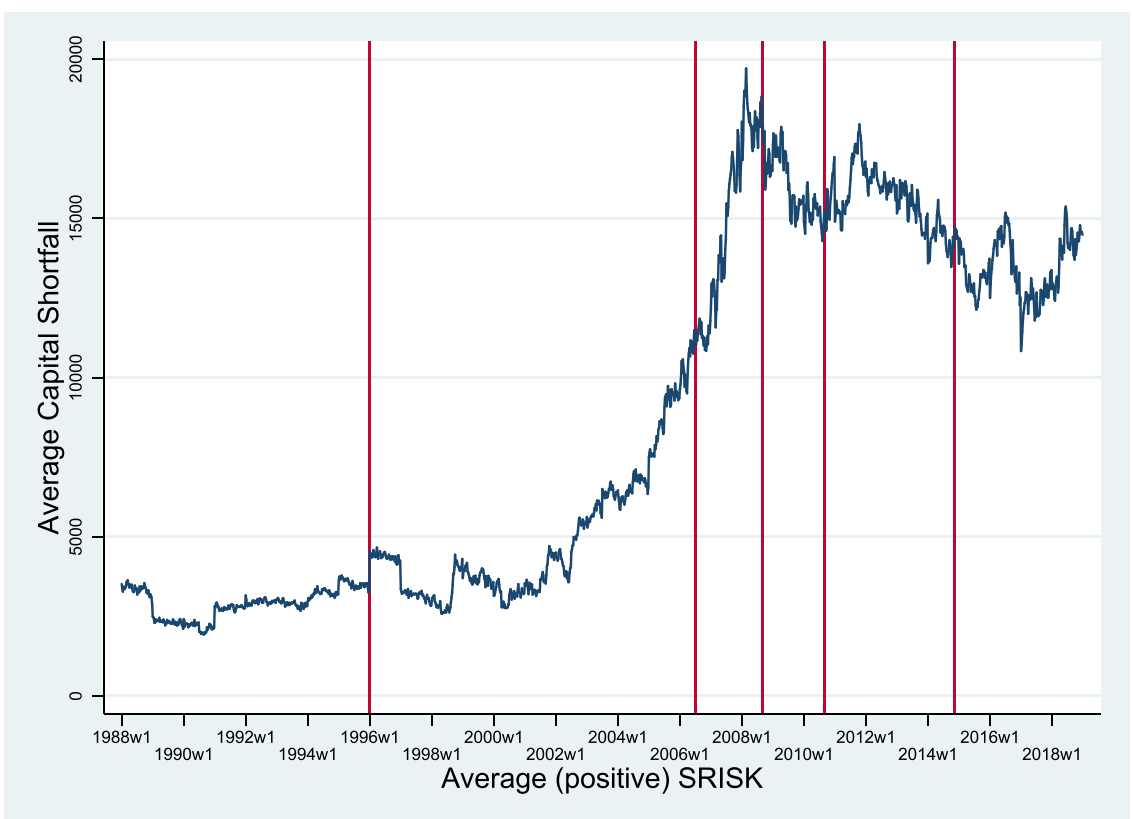

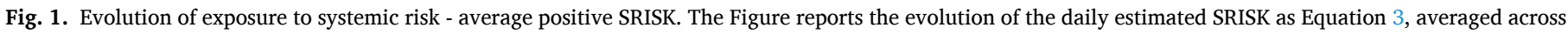
banks including only positive SRISK (capital needs or shortfalls). We use a capital ratio $\mathrm{k}=8 \%$.

systemic risk measures are the focus of current macro-prudential regulation, individual bank failure risk was the focus of prior micro-prudential regulation. Therefore, we also provide trajectories for a variant of the Z-score as modelled by Boyd and Runkle (1993).

\subsubsection{SRISK}

We measure the exposure to systemic risk by means of SRISK, the expected capital shortfall measure developed by Brownlees and Engle (2017). Formally, it is designed to measure the market value of equity required to be issued at market prices in order to render the bank compliant again with regulatory standards after a serious and protracted crisis. Theoretically, SRISK for bank $i$ in period $t$ is defined as:

$$
\begin{aligned}
& \text { SRISK }_{i, t}=E_{t-1}[\text { Capital shortfall } \mid \text { Crisis }] \\
& =E_{t-1}\left[k\left(\text { Debt }_{i}+\text { Equity }_{i}\right)-\text { Equity }_{i} \mid \text { Crisis }\right]
\end{aligned}
$$

where $k$ is the prudential capital ratio, that we assume $8 \% .{ }^{17} D e b t_{i, t}$ is book debt (total liabilities) prior to time t, while Equity $_{i, t}$ is market value of equity at time t. ${ }^{18}$

Following Brownlees and Engle (2017)), we take into account how liabilities and market capitalization of the bank react to prolonged events of crisis. In case of major market distress, debt is not renegotiated in the short term, therefore outstanding book value of debt does not change. Instead, the current equity market value falls by the Long-Run Marginal Expected Shortfall (LRMES). ${ }^{19}$ LRMES is the expected loss in equity value of bank $i$, if the market were to fall by more than a $d=40 \%$ threshold within the next six months:

\footnotetext{
17 Robustness checks have been produced with different capital ratios, ie. $5.5 \%$. However, the results do not different and they are therefore not reported here.

18 As robustness checks, we also conducted the inference analysis using capital ratios of $3 \%$ and $5.5 \%$.

19 As the authors, we assume that banks' returns follow a bivariate daily time series model of the equity returns of institution $i, r_{i, t}$, dependent on a valueweighted market index $m, r_{m, t}$. We use the MSCI Europe index for the market return $r_{m, t}$ as a representative benchmark for our sample of European banks. The return volatilities of each institution i $\sigma_{i, t}$ and of the market $\sigma_{m, t}$ are estimated by an asymmetric GJR GARCH model (Glosten et al., 1993). The correlation between each institution return and the European market index $\rho_{i, t}$ is estimated by a Dynamic Conditional Correlation (DCC) model (Engel, 2002).
}

LRMES $_{i t}=1-\exp (\ln (1-d)$ beta $)$

We estimate a dynamic market beta coefficient between the bank's return and the market return. The return volatilities of each institution $i$, $\sigma_{i, t}$ and of the market, $\sigma_{m, t}$, are estimated by an asymmetric GJR GARCH model (Glosten et al., 1993). The correlation between each institution return and the European market index, $\rho_{i, t}$ is estimated by a Dynamic Conditional Correlation (DCC) model (Engle, 2002).

Therefore, individual bank-specific SRISK, the expected capital shortfall a bank would experience in case of the above distress, can be estimated as:

$\operatorname{SRISK}_{i t}=E_{t-1}\left[k\left(\right.\right.$ Debt $\left._{i, t}\right)-(1-k)\left(1-\right.$ LRMES $\left._{i, t}\right)$ Equity $\left._{i, t}\right]$

Positive values of SRISK would represent the case of capital shortfalls, while negative SRISK represents the case of capital surpluses.

Focusing on capital shortfalls, the positive side of the distribution, the relative exposure to SRISK of a given bank $i$ in period $t$ is determined by:

$S R I S K \%_{i, t}=\frac{\text { SRISK }_{i, t}}{\sum_{j \in J} S R I S K_{j, t}}$, where $J=$ firms with SRISK $>0$

It represents the percentage aggregate capital shortfall that would be experienced by the firm in the event of a crisis, and it allows for identifying the most systemic institutions in the sector.

We report average bank-level SRISK aggregating positive shortfalls (Fig. 1). It measures the average amount of re-capitalization needed for a given capitalization standard, as an indicator of industry stress. Fig. 2 reports the total capital shortfall of European banks in terms of the annual average country GDP. It illustrates that total capital shortfall has risen from less than 5\% of GDP to about $15-20 \%$ of annual GDP. At the height of the Great Financial Crisis, capital shortfall reached almost 30\% of annual GDP.

By visual inspection of the first net-exposure measure of SRISK, three major level changes in aggregate SRISK catch the eye: i) the early stage from 1988 to 2001, ii) the period from 2002 to 2008 and the iii) sovereign crisis stage from 2009 onwards. When averaging only positive shortfalls across institutions, a steady increase of absolute exposure to systemic risk is observed until 2008, from which on it remains constant at almost 2008 levels. 


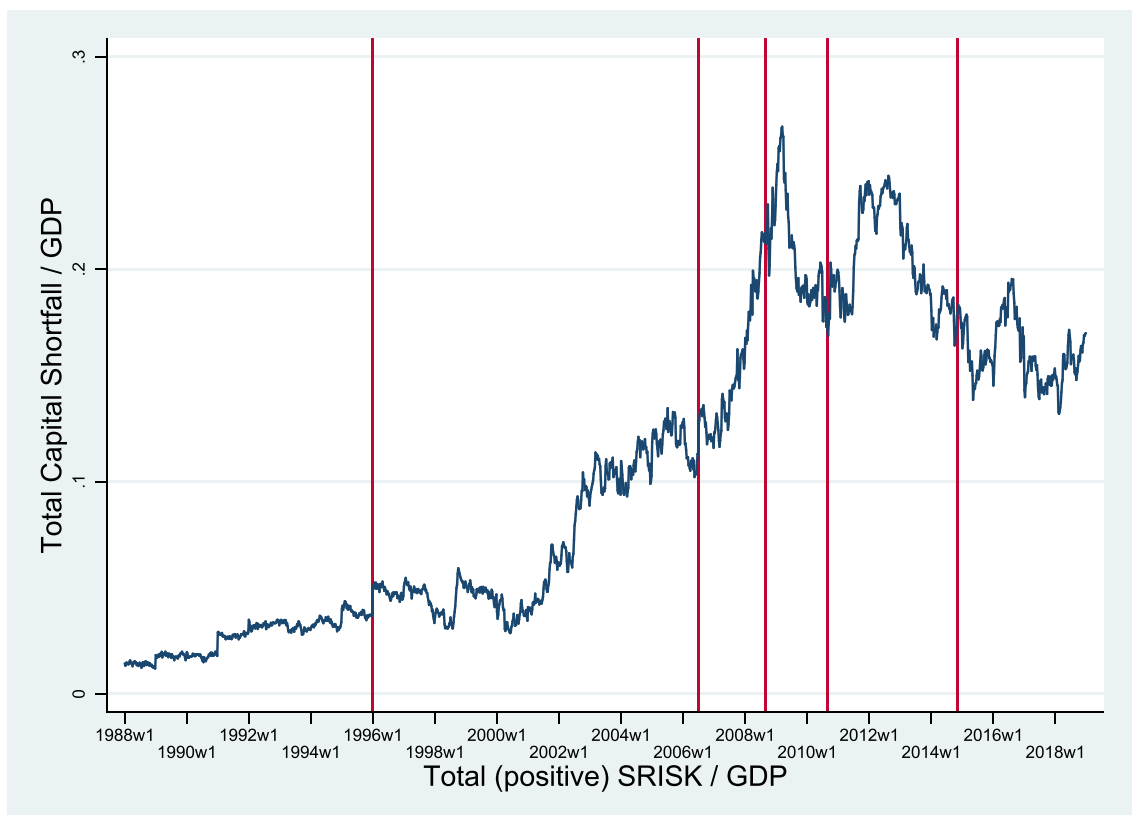

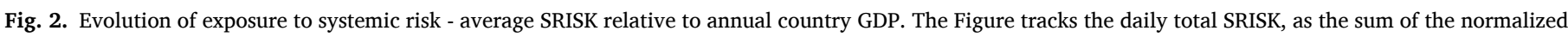

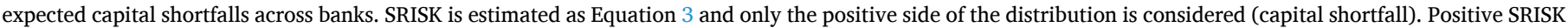
is normalized by annual country GDP.

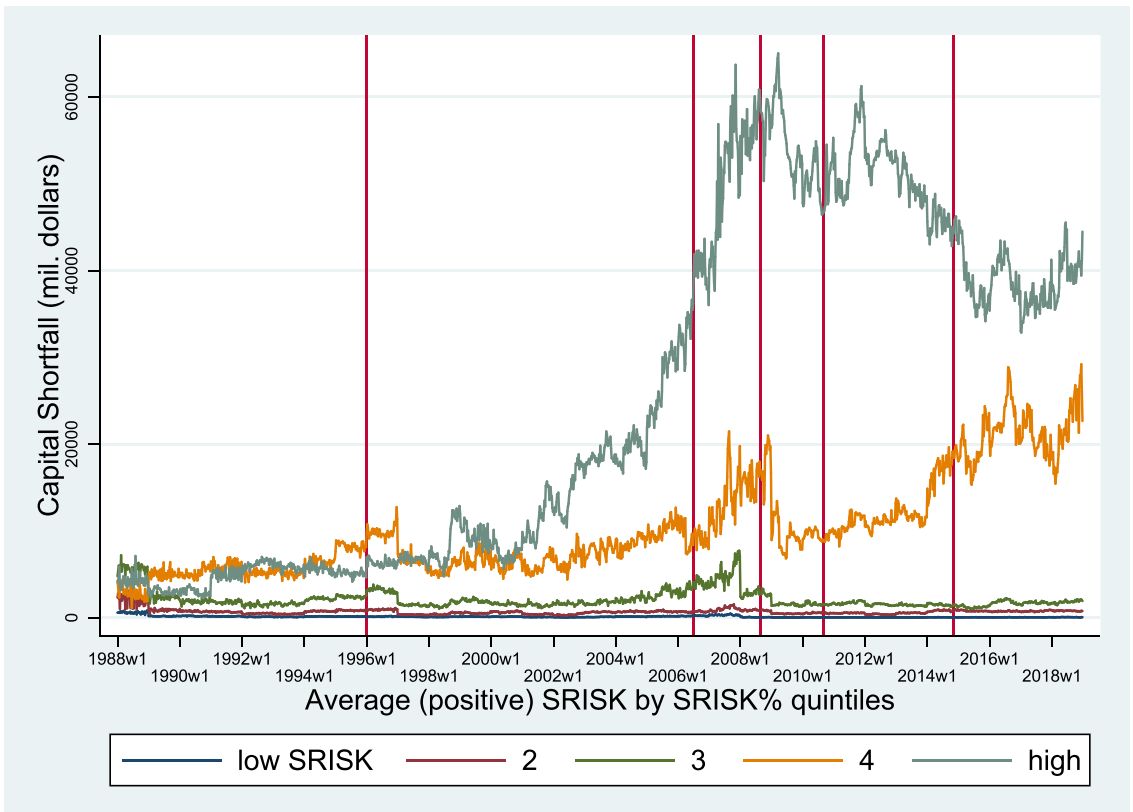

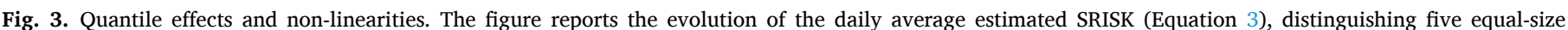

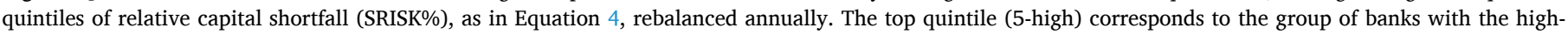
est level of positive SRISK, while the bottom quintile (1-low) corresponds to the group of banks with the lowest level of capital shortfall.

Accordingly, average relative capital shortfall has increased continuously until the Great Financial Crisis and has been reduced barely to pre-crisis levels of 2006. How does this relate to the original intentions of the BCBS?

Moreover, has capital shortfall affected all banks alike, or do we observe differences in the cross-section? In order to address this questions we analyze the quintiles of the SRISK distribution. Rebalancing every year, we divide the financial institutions into 5 groups of positive relative exposure to SRISK, and we follow the evolution of the average capital shortfall. It turns out that it is essentially the upper two quintiles that cause most of the increase in shortfall, while the risk exposure for the majority of banks has increased only slightly until 2018 (Fig. 3). In any case the trajectories do not seem to reflect a long term increase in resiliency. It is interesting to note that the introduction of internal market risk models in 1996 seems to have exerted a short-lived, but discernible, moderating effect on the SRISK-trajectories across all quintiles.

\subsubsection{Delta CoVaR}

The contribution to systemic risk can be measured by Delta CoVaR, as developed by Adrian and Brunnermeier (2016). This is a purely market-based systemic risk measure, and, in contrast to SRISK, it 


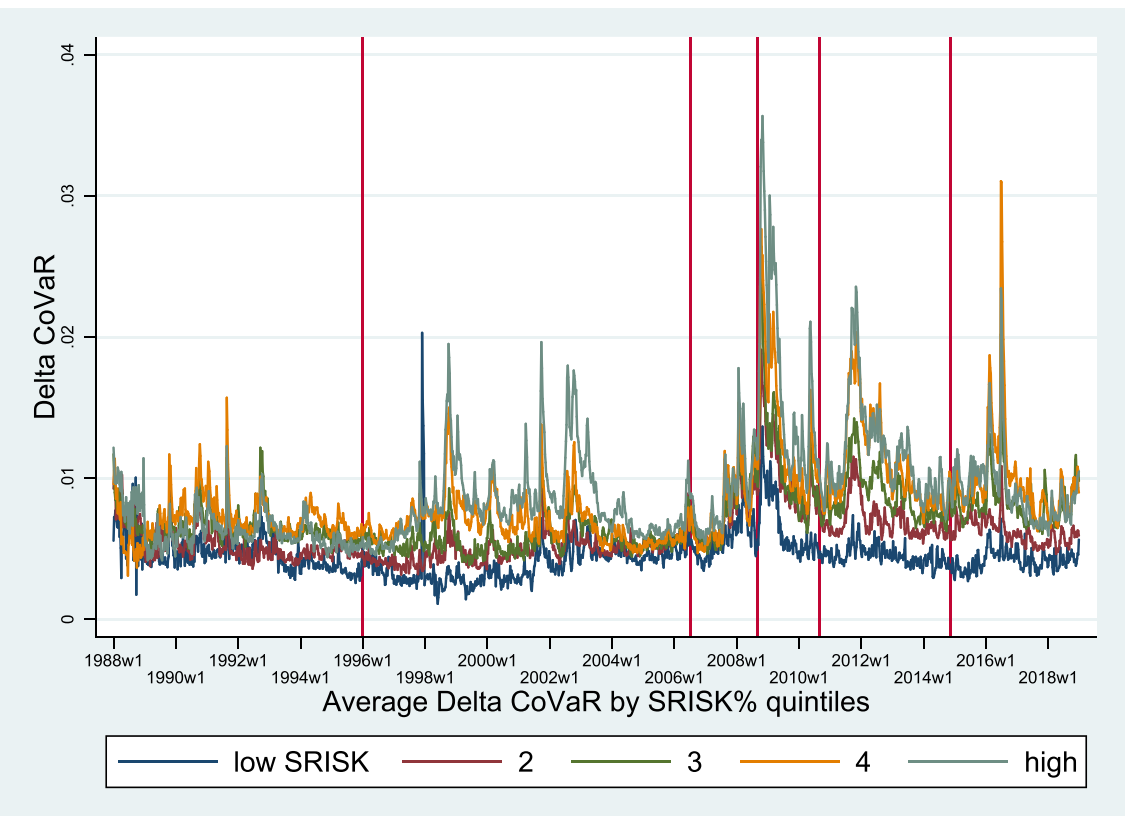

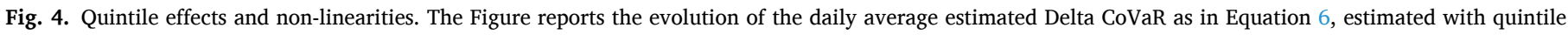

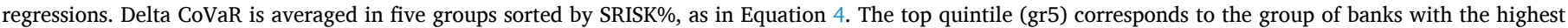
level of SRISK, while the bottom quintile (gr1) corresponds to the group of banks with the lowest level of SRISK.

measures the contribution of a financial institution to the risk of the overall financial system. Delta CoVaR is the market Value-at-Risk conditional on a bank being in distress. Hence, it measures the contagion deriving from a bank being in distress to the whole banking system.

This measure starts from the estimation of an aggregate extreme loss in terms of Value-at-Risk, as the maximum loss of the market return within the $\alpha \%$-confidence interval, conditionally on some event $C\left(r_{i t}\right)$ observed for bank i:

$\operatorname{Pr}\left(r_{m t} \leq \operatorname{CoVaR} R_{t}^{m \mid C\left(r_{i t}\right)}\right)=\alpha$

Using a quantile regression approach, we identify this distress event of firm $\mathrm{i}$ as an equity loss equal to its $(1-\alpha) \% \operatorname{VaR}$, such as $r_{i t}=\operatorname{VaR} R_{i t}(\alpha)$.

The systemic risk of the bank $i$ is then defined as the difference between the CoVaR of the financial system conditional on firm i being in distress and the CoVaR of the financial system conditional on firm $i$ being in its median state:

$\Delta \operatorname{CoVaR}_{i t}(\alpha)=\left(\operatorname{CoVaR}_{t}^{m \mid r_{i t}=\left(\operatorname{VaR}_{i t}(\alpha)\right)}-\operatorname{CoVaR} R_{t}^{m \mid r_{i t}=\operatorname{Median}\left(r_{i t}\right)}\right)$

As its authors, we will transform Delta CoVaR to positive values. ${ }^{20}$

The trajectories of Delta CoVaR differ significantly from SRISK. This measure peaks at the time of prominent crisis events, such as around the Lehman failure in September 2008. To the effect that the subprime crisis has been characterized by a drying-up of liquidity, it appears remarkable that contagion risk has not shot up dramatically during the 2007-8 period prior to the Lehman insolvency.

Comparing Delta CoVaR and SRISK quintiles (Fig. 4), we see how the banks with the highest contribution to systemic risk tend to be also the banks with the highest SRISK throughout the time series (Fig. 4). Moreover, the difference in Delta CoVaR between low and high SRISK groups is widened after the $2009-10$ crisis.

\subsubsection{Individual bank risk measures}

How about individual bank risk rather than systemic concerns? Did

\footnotetext{
${ }^{20}$ In the regression analysis, we will express it in dollar terms, thus weighting it with the market capitalization of bank $i$.
}

the Basel process succeed to significantly enhance the resiliency of individual banks? In order to address these questions we analyze the trajectories of individual bank measures of default. Distance-to-default is widely proxied in the banking literature by the Z-score (Boyd and Runkle, 1993; Fiordelisi and Marques-Ibanez, 2013). It measures the distance of bank's ROA to the insolvency threshold in multiples of standard deviations.

Z-score is a measure of the degree of solvency of an individual bank. It combines information on bank's performance (ROA), leverage (equity-to-assets ratio), and risk (standard deviation of ROA). Higher values of Z-score represent a higher degree of solvency, as it represents a distance-to-default, as number of standard deviations away from the bank's ROA augmented by the Equity-to-Assets ratio.

We estimate a simplified version of Z-score for each institution, as:

$Z-$ score $_{i t}=\frac{R O A_{i t}+E_{i t} / T A_{i t}}{\sigma_{R O A_{i}}}$

Again it is illustrative to take a cross-sectional perspective (Fig. 5). Accordingly, we sort banks according to their SRISK scores and trace their Z-score trajectories. It becomes readily apparent that resiliency has been increasing for the lowest quintiles of the SRISK-distribution, while it has been mainly stationary for the highest risk groups and only slightly increasing after 2004.

In other words, across almost three decades, individual bank risk has been significantly reduced for the quintiles of banks that pose the smallest systemic concerns according to their SRISK-scores. This is particularly clear for the second group of SRISK, while less striking for the lowest quintile. On the other side, for the upper two SRISK-quintiles, long-run improvement of the Z-score is not striking.

Summarizing the evidence on the three risk measures, we observe quite heterogeneous and unequal developments across our sample of banks. While banks associated with the lower three SRISK-quintiles have become and remained safe from a systemic point of view, the most systemic banks associated with the higher SRISK quintiles have not. The evidence presented so far does not speak in favor of a general increase in safety and soundness across the whole banking system despite regulatory efforts and numerous steps of reform during the Basel process of capital regulation. The evidence, however, does not necessarily speak 


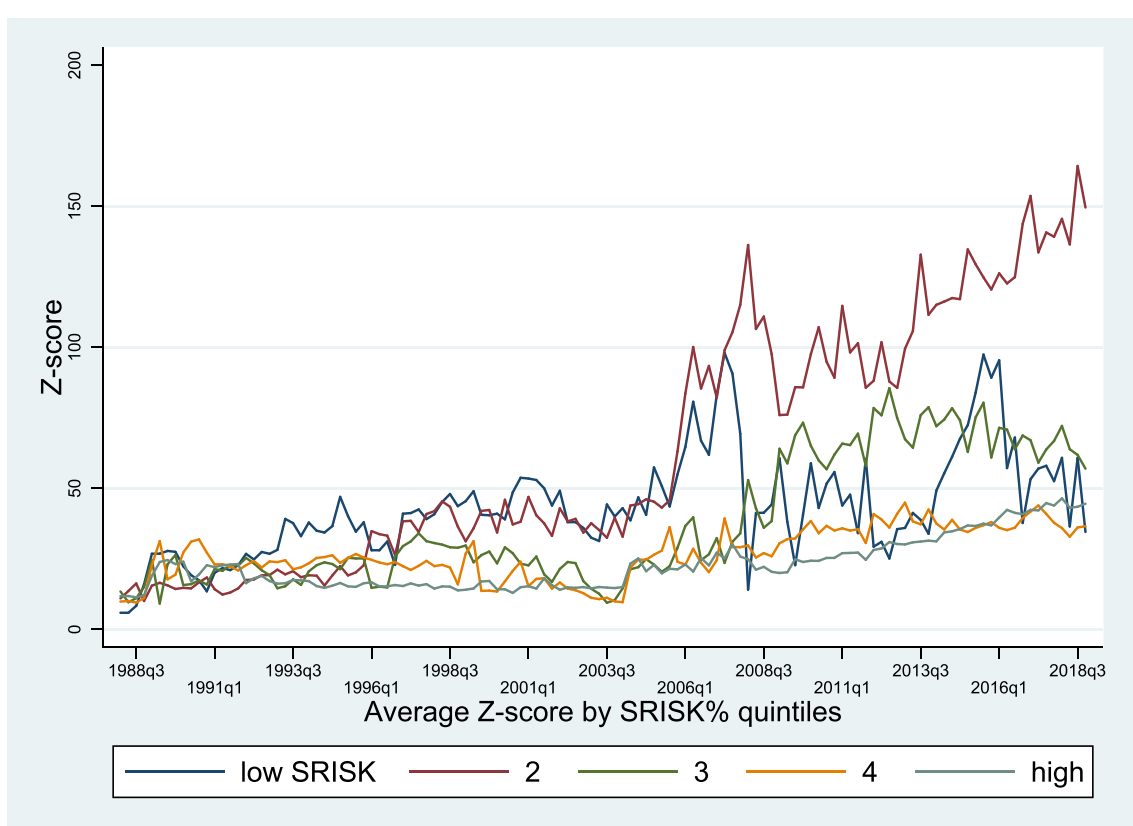

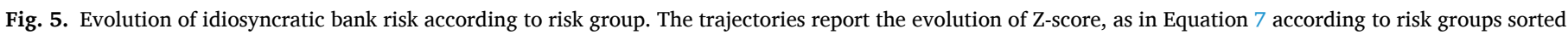

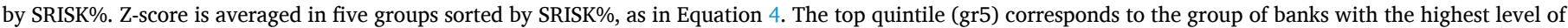
SRISK, while the bottom quintile (gr1) corresponds to the group of banks with the lowest level of SRISK.

against the success of regulatory reform per se, since the decrease in resiliency might just reflect an increasingly more risky environment of the global banking business. For such an assessment a deeper multivariate analysis is required that controls for the observable risk factors.

\section{Sources of bank risk}

Let us now analyse how the various risk measures relate to the economic and political conditions. To what extent can these observations be related to the realization of standard risk factors and to what extent are they affected, moderated or amplified by regulatory intervention? We will analyze systemic risk exposure first, and then individual banking risk. We will apply quantile regressions to allow for the distributional heterogeneity observed above in the descriptive analyses of Section 3.2.

We use a sub-sample of 99 banks given data availability on the internal models implementation. On the level of policy variables, we have detailed bank-level information about internal credit risk models (IRBA). In particular, we know when banks were given permission to implement which type of model. We refer to the above description of our sample in Section 3.1.

\subsection{Sources of capital shortfall}

Let us start with a focus on SRISK as a measure of the exposure of an institution to systemic risk. As a hybrid measure, it relates market values to book values, combining the bank's sensitivity to market returns and its leverage. Thus, in the analysis of its sources, we include both market and bank characteristics. As SRISK is a market variable of risk, we consider that all known drivers of bank asset prices will also affect SRISK. Therefore, we address the main factors in the asset pricing literature, market return, size and market-to-book, as drivers of market prices that could introduce endogeneity in our model. The Basel process is captured by bank-level information on the implementation of internal models for credit risk, and by Basel time dummies that identify the major steps of the Basel regulation over the years.

Since we observe important nonlinearities in SRISK, we use quantile regressions to address potentially differential effects of our covariates across three quartiles of the distribution of SRISK. We use an unconditional quantile approach as (Firpo et al., 2009), where we marginalize the quantile coefficients using the recentered influence function. The interpretation of the estimated coefficients therefore corresponds to the usual interpretation, as the marginal effect on the unconditional quantile of SRISK of a location shift in the distribution of the covariates, ceteris paribus.

We regress a dynamic panel data model of weekly SRISK, as it follows:

SRISK $_{i t}=\alpha+\operatorname{L.SRISK}_{i t} \gamma_{0}+Z^{\prime} \gamma_{z}+X^{\prime} \gamma_{x}$

$+I R B A^{\prime} \lambda_{i m}+\left(I R B A_{i t}{ }^{*} M V\right)^{\prime} \lambda_{i m m}$

$+B A S E L^{\prime} \lambda_{b}+\mu_{i}+\varepsilon_{i t}$

An innovative element of our analysis is the investigation of the impact of the introduction of self-regulatory tools looking at credit risk internal models, IRBA. One of the pillars of Basel II is the option to widen the scope for internal models also to cover credit risks. While at this stage we do not have sufficiently many (micro) data on the implementation or approval of internal models for market risk, we obtained this micro information about approval and/or adoption of internal credit rating models for our sub-sample of 99 European banks.

Banks are classified into two IRBA groups according to whether they select approaches where the parameters are largely determined by the supervisors, or they apply the more aggressive models estimating most of the parameters by their own analytics. The former group is picked by the variable IRBA-S/F, that takes value 1 for banks $i$ implementing the Standardized or the Foundation-IRBA for credit risk after the implementation date, and 0 otherwise and before the implementation of Basel II. Similarly, IRBA-A/M is set to 1 at the date at which the mixed or the advanced models for credit risks have been implemented at bank $i$. Banks that implement internal models tend to be larger in size, therefore we include the IRBA dummies with and without interaction with the market value of the bank, centered at its mean to ease interpretation.

Moreover, the Basel regulation is captured by the introduction of time dummies highlighting the main steps of the regulatory process. Keeping "Basel I" (1: before 1996) out, we include: "Market Risk Amendment" (1: between 1996 and June 2006), "Basel II" (1: between June 2006 and September 2008), "Basel III" (1: between September 2008 and September 2010), and "Banking Union" (1: after November 2014). We also include a time dummy to isolate the effect of the 
"European Crisis", taking value 1 between September 2010 to November 2014. In the Appendix, we report a robustness check where we introduce year effects, instead of the above Basel dummies.

We control for market characteristics $\left(X_{q t}\right)$ and bank characteristics $\left(Z_{k i t}\right)$, and Table 4 in the Appendix reports more details on the variables used. Among the market-characteristics variables, we include countryspecific factors and proxies for market investment opportunities: (i) country equity market return, (ii) country short-term interest rates, (iii) ECB composite indicator of systemic stress, CISS (Holló et al., 2012), and (iv) total amount of assets held by ECB for monetary policy. These variables should address the changing characteristics, as opportunities and stress, arising in the overall financial markets. Then, we expect SRISK to be positively correlated with other measures of market stress. In particular, we assume that the CISS indicator will flag earlier than individual SRISK, thus, we expect a positive relation between a lagged CISS and SRISK (Holló et al., 2012). Moreover, the introduction of country interest rates allow us to control for growth opportunities, while the total amount of assets held by the ECB for monetary policy would proxy for the unconditional monetary policy in the most recent years.

The following bank-characteristics variables are included: (i) dynamic market beta, (ii) market capitalization, (iii) Z-score, (iv) leverage ratio, (v) market over- or undervaluation, following the book-to-market decomposition of Rhodes-Kropf et al. (2005), ,1 and (vi) Globally Systemic Banks (G-SIBs) dummies. These variables capture the time-changing cross-sectional differences in risk characteristics, and systemic risk is particularly affected by size, leverage and asset risk (Hovakimian et al., 2012). We expect larger banks to exhibit higher systemic exposures, given their complexity and interconnectedness. We then take a positive relationship between SRISK and market beta and distance-to-default (opposite to Z-score) as proxies for idiosyncratic risk. Moreover, we assume that highly levered banks contribute more to systemic risk, therefore we expect a positive relation between SRISK and leverage (Beltratti and Stulz, 2012). We then consider that misvaluation from the market would negatively affect SRISK. Since SRISK is a market-based risk measure, we expect it to underestimate the true exposure to systemic risk in periods of high sentiment, and to overestimate the true exposure to systemic risk in periods of underpricing. In order to avoid issues of multicollinearity using the book-to-market value directly, we rely to the decomposition of Rhodes-Kropf et al. (2005), considering the misvaluation from the historical industry norm. Moreover, the G-SIB dummies are designed to capture two effects: we include a fixed effect dummy that identifies the whole time series of a global systemically relevant institution, defined as such at least once by the Financial Stability Board (FSB). Moreover, we include a dummy that takes value 1 in the years a bank is included in the list of G-SIBs by the FSB-BCBS. As we expect a positive sign for the former dummy, the latter G-SIBs variable would identify the impact on SRISK due to the imposition of extra capital to these institutions since $2012 .^{22}$

Finally, we use individual effects as country fixed effects. Thus, we

\footnotetext{
21 The firm misvaluation is estimated considering both firm-specific deviations from the valuation in the current sector, and sector deviations from long-run industry multiples.

${ }^{22}$ We have refrained from an explicit analysis of all individual buckets, because of low numbers of banks in some buckets as compared to the overall sample, especially in the highest buckets. Similarly, we rely on the BCBS identification and we do use alternative approaches such as Benoit et al. (2019). On one side, the BCBS identification allows us to use the full time series until its introduction. On the other side, comparing their scores with the BCBS scores, Benoit et al. (2019) observe that (i) the systemic-risk scores are very strongly correlated, with rank correlations greater than $90 \%$ and correlation with SRISK between $56 \%$ and $60 \%$, (ii) there are far more cases of switching buckets than belonging to the SIFIs group ( 3 banks in 2015 and 1 in 2016). As we do not use the buckets information but refer to a single dummy for being a SIFIs or not, we will reduce the information in the new measure anyway while we already limit the issues of mis-classification.
}

allow for supervisory heterogeneity across jurisdictions as well as for other country-specific differences, such as regional economic conditions. Literature shows that the characteristics of the regulatory regime impact on the risk-taking behaviour of the banking institutions (Barth et al., 2013; Ongena et al., 2013; Laeven and Levine, 2009). ${ }^{23}$ We also consider a robustness exercise with firm fixed effects and country macro variables. We use unemployment rate, GDP growth and PPI to capture the major economic conditions for each country. ${ }^{24}$ Table 1 reports our key results and demonstrates that the policy impact of different Basel policy instruments is quite heterogeneous and non-linear across the cross-section of European banks.

Interestingly, the introduction of market risk models in 1996 (Jan1996-Jun2006) is associated with a risk-reducing effect in the lower two quartiles, while the dummy significantly contributes to SRISK for the highest quartile. This is in line with the descriptive trajectories of Fig. 3 and suggests that banks' reaction to the Market Risk Amendment of Basel I has been quite different across the cross-section. Likewise, we find that the implementation of Basel II regulation (Jun2006-Sep2008) had a risk-reducing effect on the lower quartile banks, but not in the highest quartile. Similarly, the Basel III dummy (Sep2008-Sep2010) as well as the Banking Union dummy (Nov2014-Dec2018) did all contribute to reduce systemic risk for the lower quartiles, but not for the highest quartile, where SRISK is actually increased in the interaction model.

Concerning the choice of credit risk model under Basel II, we observe differential effects again across the cross-section. While the passive standard and foundation approach, indicated by IRBA-S/F, did contribute to reduce systemic risk for the higher quartile banks, the more aggressive mixed and advanced models, IRBA-A/M, contributed to significantly increase SRISK. Moreover, within each quartile, the riskenhancing effect of the aggressive risk models are even greater for the larger banks. On average, banks applying advanced or mixed internal models exhibit a higher level of SRISK. Moreover, the interaction terms show that the difference in SRISK between banks using internal models widens as size increases. The larger the bankis, the larger will be the effect on systemic risk for banks using advanced internal models.

Taken together, we find that the process of Basel regulation did contribute to reduce systemic risk in the lower quartiles even in the early years, when the focus of regulation was more concentrated on microprudential concerns. Paradoxically, for the upper quartile the process effectively contributed to significant increases in capital shortfall (SRISK), even in the early years. Similarly we find differential effects across banking quartiles also for the introduction of internal models for market risk. Only in the case of internal credit risk models, we find a risk-enhancing effect across all quartiles and even stronger for larger banks within each quartile.

Concerning the Basel III measures of globally systemically important banks, we verify that the G-SIB-allocation (G-SIB FE) is correlated with high SRISK-exposure progressively across quartiles. Moreover, the implementation of G-SIB-surcharges after 2012 (G-SIB) contributes to reduce capital shortfall, also progressively across quartiles.

Also monetary policy affects financial stability differentially. While short-term interest rates (ST interest rates) uniformly related negatively with SRISK, measures of unconventional monetary policy (ECB Mon. Policy Assets) exert differential impact across banks. The ECB asset purchase programme seems to have a reducing effect on SRISK for the lower quartiles, but unconventional monetary policy measures are positively related with systemic risk for the riskiest quartile.

The standard controls as well as the drivers of bank stock prices exert the expected results. Systematic risk, as measured by Beta, leverage and

\footnotetext{
23 As many of the regulatory proxies in the literature are not going back to the past as our study would need or have lower frequency, we rely on country effects.

${ }^{24}$ The results are reported in the Appendix.
} 
Table 1

Unconditional quantile regressions of SRISK with basel time dummies.

\begin{tabular}{|c|c|c|c|c|c|c|}
\hline VARIABLES & $\begin{array}{l}(1) \\
\text { Q.25 }\end{array}$ & $\begin{array}{l}(2) \\
Q .5\end{array}$ & $\begin{array}{l}(3) \\
Q .75\end{array}$ & $\begin{array}{l}\text { (4) } \\
\text { Q.25 }\end{array}$ & $\begin{array}{l}(5) \\
\text { Q.5 }\end{array}$ & $\begin{array}{l}(6) \\
Q .75\end{array}$ \\
\hline L.SRISK & $\begin{array}{l}0.00531^{* * * *} \\
(0.000223)\end{array}$ & $\begin{array}{l}0.0103^{* * *} \\
(0.000532)\end{array}$ & $\begin{array}{l}0.360 * * * \\
(0.00544)\end{array}$ & $\begin{array}{l}0.00494 * * * \\
(0.000220)\end{array}$ & $\begin{array}{l}0.00952^{* * *} \\
(0.000529)\end{array}$ & $\begin{array}{l}0.356^{* * *} \\
(0.00544)\end{array}$ \\
\hline Beta & $\begin{array}{l}326.6^{* * *} \\
(12.28)\end{array}$ & $\begin{array}{l}2164^{* * * *} \\
(33.42)\end{array}$ & $\begin{array}{l}8858^{* * *} \\
(200.5)\end{array}$ & $\begin{array}{l}371.8^{* * *} \\
(12.53)\end{array}$ & $\begin{array}{l}2262^{* * * *} \\
(34.70)\end{array}$ & $\begin{array}{l}9256^{* * * *} \\
(204.2)\end{array}$ \\
\hline Z-score & $\begin{array}{l}-2.018 * * * \\
(0.139)\end{array}$ & $\begin{array}{l}-3.882^{* * *} \\
(0.246)\end{array}$ & $\begin{array}{l}-60.90 * * * \\
(1.112)\end{array}$ & $\begin{array}{l}-2.039 * * * \\
(0.139)\end{array}$ & $\begin{array}{l}-4.002^{* * *} \\
(0.248)\end{array}$ & $\begin{array}{l}-61.02 * * * \\
(1.121)\end{array}$ \\
\hline LVG & $\begin{array}{l}16.13^{* * * *} \\
(0.225)\end{array}$ & $\begin{array}{l}32.88^{* * *} \\
(0.394)\end{array}$ & $\begin{array}{l}86.31 * * * \\
(2.919)\end{array}$ & $\begin{array}{l}16.92^{* * *} \\
(0.224)\end{array}$ & $\begin{array}{l}34.75^{* * * *} \\
(0.390)\end{array}$ & $\begin{array}{l}93.15^{* * *} \\
(2.984)\end{array}$ \\
\hline G-SIB FE & $\begin{array}{l}730.8^{* * *} \\
(17.89)\end{array}$ & $\begin{array}{l}2316^{* * * *} \\
(36.84)\end{array}$ & $\begin{array}{l}22,934 \text { *** } \\
(328.8)\end{array}$ & $\begin{array}{l}732.8^{* * *} \\
(17.72)\end{array}$ & $\begin{array}{l}2323^{* * *} \\
(36.42)\end{array}$ & $\begin{array}{l}22,949^{* * *} \\
(327.5)\end{array}$ \\
\hline G-SIB & $\begin{array}{l}-600.3^{* * *} \\
(20.30)\end{array}$ & $\begin{array}{l}-1028^{* * *} \\
(47.70)\end{array}$ & $\begin{array}{l}-1620 * * * \\
(486.5)\end{array}$ & $\begin{array}{l}-607.5^{* * *} \\
(20.02)\end{array}$ & $\begin{array}{l}-1056^{* * *} \\
(47.02)\end{array}$ & $\begin{array}{l}-167^{* * *} \\
(483.2)\end{array}$ \\
\hline CISS & $\begin{array}{l}-396.2^{* * * *} \\
(49.00)\end{array}$ & $\begin{array}{l}-477.0^{* * * *} \\
(89.23)\end{array}$ & $\begin{array}{l}1538^{* *} \\
(643.8)\end{array}$ & $\begin{array}{l}-309.2^{* * *} \\
(49.84)\end{array}$ & $\begin{array}{l}-180.2^{* *} \\
(90.59)\end{array}$ & $\begin{array}{l}2214^{* * *} \\
(649.1)\end{array}$ \\
\hline Market Return & $\begin{array}{l}922.4 \\
(871.7)\end{array}$ & $\begin{array}{l}1501 \\
(1658)\end{array}$ & $\begin{array}{l}2565 \\
(11,744)\end{array}$ & $\begin{array}{l}1088 \\
(868.3)\end{array}$ & $\begin{array}{l}1858 \\
(1655)\end{array}$ & $\begin{array}{l}4030 \\
(11,707)\end{array}$ \\
\hline ST interest rates & $\begin{array}{l}-66.84^{* * *} \\
(4.323)\end{array}$ & $\begin{array}{l}-47.84 * * * \\
(7.885)\end{array}$ & $\begin{array}{l}-682.7^{* * *} \\
(53.93)\end{array}$ & $\begin{array}{l}-74.05^{* * *} \\
(4.508)\end{array}$ & $\begin{array}{l}-68.49 * * * \\
(8.349)\end{array}$ & $\begin{array}{l}-742.0^{* * * *} \\
(55.62)\end{array}$ \\
\hline ECB Mon. Policy Assets & $\begin{array}{l}-1.74 \mathrm{e}-05 \\
(1.06 \mathrm{e}-05)\end{array}$ & $\begin{array}{l}-0.000141^{* * *} \\
(2.24 \mathrm{e}-05)\end{array}$ & $\begin{array}{l}1.62 \mathrm{e}-05 \\
(0.000161)\end{array}$ & $\begin{array}{l}-2.49 \mathrm{e}-05^{* *} \\
(1.05 \mathrm{e}-05)\end{array}$ & $\begin{array}{l}-0.000146^{* * *} \\
(2.24 \mathrm{e}-05)\end{array}$ & $\begin{array}{l}-5.99 e-05 \\
(0.000161)\end{array}$ \\
\hline Misvaluation & $\begin{array}{l}-801.5^{* * *} \\
(13.12)\end{array}$ & $\begin{array}{l}-618.4^{* * *} \\
(19.09)\end{array}$ & $\begin{array}{l}43.86 \\
(104.5)\end{array}$ & $\begin{array}{l}-796.0^{* * *} \\
(13.14)\end{array}$ & $\begin{array}{l}-603.5^{* * *} \\
(18.74)\end{array}$ & $\begin{array}{l}89.24 \\
(103.7)\end{array}$ \\
\hline MV (centered) & $\begin{array}{l}-62.43^{* * *} \\
(6.954)\end{array}$ & $\begin{array}{l}277.7 * * * \\
(11.81)\end{array}$ & $\begin{array}{l}3050 * * * \\
(80.84)\end{array}$ & $\begin{array}{l}-196.9^{* * *} \\
(10.52)\end{array}$ & $\begin{array}{l}-143.8^{* * * *} \\
(17.60)\end{array}$ & $\begin{array}{l}1973 * * * \\
(124.1)\end{array}$ \\
\hline IRBA-S/F & $\begin{array}{l}180.1^{*} \\
(101.7)\end{array}$ & $\begin{array}{l}-335.8^{* *} \\
(161.5)\end{array}$ & $\begin{array}{l}-2707^{* * *} \\
(978.9)\end{array}$ & $\begin{array}{l}13.58 \\
(104.0)\end{array}$ & $\begin{array}{l}-1026^{* * *} \\
(163.1)\end{array}$ & $\begin{array}{l}-3897 * * * \\
(995.4)\end{array}$ \\
\hline IRBA-A/M & $\begin{array}{l}877.3^{* * *} \\
(102.6)\end{array}$ & $\begin{array}{l}1418^{* * *} \\
(164.7)\end{array}$ & $\begin{array}{l}9123^{* * *} \\
(1008)\end{array}$ & $\begin{array}{l}616.8^{* * *} \\
(105.1)\end{array}$ & $\begin{array}{l}571.5^{* * *} \\
(166.8)\end{array}$ & $\begin{array}{l}7063^{* * *} \\
(1029)\end{array}$ \\
\hline IRBA-S/F \# MV & & & & $\begin{array}{l}128.5^{* * *} \\
(14.40)\end{array}$ & $\begin{array}{l}589.8^{* * *} \\
(24.33)\end{array}$ & $\begin{array}{l}869.7^{* * *} \\
(156.6)\end{array}$ \\
\hline IRBA-A/M \# MV & & & & $\begin{array}{l}450.3^{* * *} \\
(14.28)\end{array}$ & $\begin{array}{l}970.1^{* * *} \\
(30.79)\end{array}$ & $\begin{array}{l}3982^{* * *} \\
(277.6)\end{array}$ \\
\hline Jan1996- Jun2006 & $\begin{array}{l}-912.2 * * * \\
(26.99)\end{array}$ & $\begin{array}{l}-1270 * * * \\
(55.42)\end{array}$ & $\begin{array}{l}4633 * * * \\
(455.4)\end{array}$ & $\begin{array}{l}-828.8^{* * *} \\
(27.67)\end{array}$ & $\begin{array}{l}-1005^{* * *} \\
(57.02)\end{array}$ & $\begin{array}{l}5298 * * * \\
(456.7)\end{array}$ \\
\hline Jun2006- Sep2008 & $\begin{array}{l}-1187 * * * \\
(104.3)\end{array}$ & $\begin{array}{l}-1480^{* * *} \\
(169.8)\end{array}$ & $\begin{array}{l}2265^{* *} \\
(1070)\end{array}$ & $\begin{array}{l}-953.1^{* * *} \\
(106.1)\end{array}$ & $\begin{array}{l}-751.6^{* * *} \\
(171.0)\end{array}$ & $\begin{array}{l}4145^{* * *} \\
(1079)\end{array}$ \\
\hline Sep2008- Sep2010 & $\begin{array}{l}-1268 * * * \\
(111.6)\end{array}$ & $\begin{array}{l}-1422^{* * *} \\
(184.3)\end{array}$ & $\begin{array}{l}-943.4 \\
(1191)\end{array}$ & $\begin{array}{l}-1039 * * * \\
(114.1)\end{array}$ & $\begin{array}{l}-545.6^{* * *} \\
(187.5)\end{array}$ & $\begin{array}{l}761.8 \\
(1208)\end{array}$ \\
\hline Sep2010- Nov2014 & $\begin{array}{l}-1299 * * * \\
(110.3)\end{array}$ & $\begin{array}{l}-1547^{* * *} \\
(181.5)\end{array}$ & $\begin{array}{l}1100 \\
(1168)\end{array}$ & $\begin{array}{l}-1037 * * * \\
(113.2)\end{array}$ & $\begin{array}{l}-587.5^{* * *} \\
(184.9)\end{array}$ & $\begin{array}{l}3081^{* * *} \\
(1184)\end{array}$ \\
\hline Nov2014- Dec2018 & $\begin{array}{l}-1286^{* * *} \\
(111.9)\end{array}$ & $\begin{array}{l}-1279 * * * \\
(185.3)\end{array}$ & $\begin{array}{l}1689 \\
(1195)\end{array}$ & $\begin{array}{l}-1030 * * * \\
(114.7)\end{array}$ & $\begin{array}{l}-337.9 * \\
(188.6)\end{array}$ & $\begin{array}{l}3622^{* * *} \\
(1211)\end{array}$ \\
\hline Country effects & yes & yes & yes & yes & yes & yes \\
\hline Constant & $\begin{array}{l}685.0 * * * \\
(42.18)\end{array}$ & $\begin{array}{l}-1048^{* * *} \\
(83.73)\end{array}$ & $\begin{array}{l}-9601 * * * \\
(594.9)\end{array}$ & $\begin{array}{l}539.5^{* * *} \\
(43.47)\end{array}$ & $\begin{array}{l}-1480^{* * *} \\
(86.51)\end{array}$ & $\begin{array}{l}-10,787^{* * *} \\
(602.0)\end{array}$ \\
\hline Observations & 98,211 & 98,211 & 98,211 & 98,211 & 98,211 & 98,211 \\
\hline Number of banks & 99 & 99 & 99 & 99 & 99 & 99 \\
\hline R-squared & 0.352 & 0.467 & 0.591 & 0.357 & 0.473 & 0.592 \\
\hline RMSE & 1528 & 2870 & 21476 & 1522 & 2855 & 21,441 \\
\hline Percentile & -20.2819 & 1065.176 & 8999.354 & -20.2819 & 1065.176 & 8999.354 \\
\hline Norm. RMSE & 75.34 & 2.69 & 2.39 & 75.04 & 2.68 & 2.38 \\
\hline
\end{tabular}

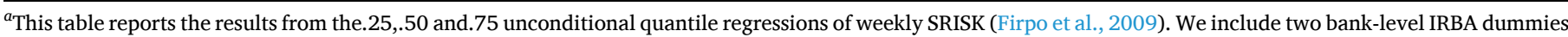

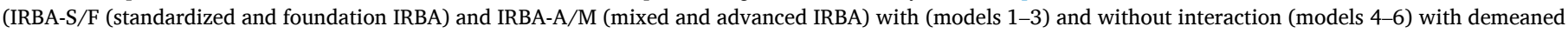

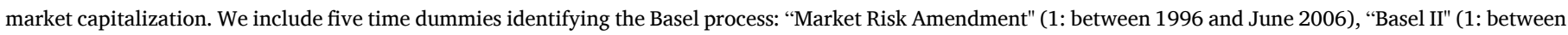

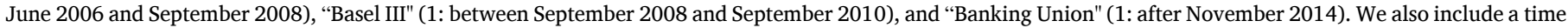

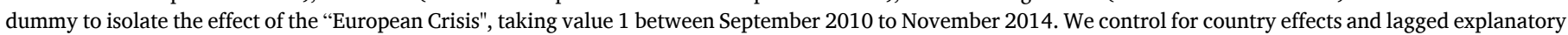

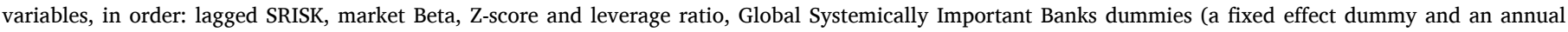

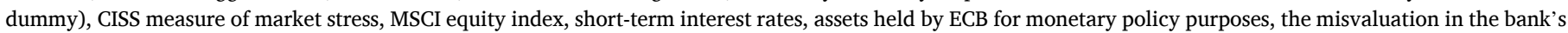

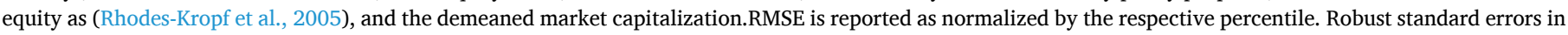
parentheses. ${ }^{* * *} \mathrm{p}<0.01,{ }^{* *} \mathrm{p}<0.05,{ }^{*} \mathrm{p}<0.1$.

distance-to-default (opposite of Z-score), are positively correlated with the exposure to systemic risk measured by SRISK. ${ }^{25}$ Size is related to higher capital shortfall as well as the market stress indicator for the highest quartile. Market overvaluation on the other hand is negatively

\footnotetext{
25 Accordingly, price bubbles in bank stocks are stabilizing according to our SRISK measure. This may be seen as a limiting feature in using SRISK for predictive purposes. Nevertheless the measure is forceful in backward looking expost evaluations across longer periods.
}

related to capital shortfall only for the lower quartiles. Country effects are strong and significant. ${ }^{26}$

These results are fairly robust with respect to different models, different measures of systematic risk or contribution to systemic risk not

\footnotetext{
26 The country effects relate to differential country-specific supervision as well as country-specific economic performance. Since we do not further separate those forces we do not present the details, which are available from the authors upon demand.
} 
Table 2

Unconditional quantile regressions of Z-Score.

\begin{tabular}{|c|c|c|c|c|c|c|}
\hline & $\begin{array}{l}(1) \\
\text { Q.25 }\end{array}$ & $\begin{array}{l}(2) \\
Q .5\end{array}$ & $\begin{array}{l}\text { (3) } \\
\text { Q.75 }\end{array}$ & $\begin{array}{l}(4) \\
Q .25\end{array}$ & $\begin{array}{l}(5) \\
Q .5\end{array}$ & $\begin{array}{l}(6) \\
\text { Q.75 }\end{array}$ \\
\hline L.Z-score & $\begin{array}{l}0.105^{* * *} \\
(0.00386)\end{array}$ & $\begin{array}{l}0.271^{* * *} \\
(0.00700)\end{array}$ & $\begin{array}{l}0.954 * * * \\
(0.0197)\end{array}$ & $\begin{array}{l}0.105^{* * *} \\
(0.00386)\end{array}$ & $\begin{array}{l}0.271^{* * *} \\
(0.00704)\end{array}$ & $\begin{array}{l}0.954 * * * \\
(0.0197)\end{array}$ \\
\hline Beta & $\begin{array}{l}2.093^{* * *} \\
(0.433)\end{array}$ & $\begin{array}{l}0.0411 \\
(0.667)\end{array}$ & $\begin{array}{l}-6.460 * * * \\
(1.584)\end{array}$ & $\begin{array}{l}2.124 * * * \\
(0.434)\end{array}$ & $\begin{array}{l}0.120 \\
(0.672)\end{array}$ & $\begin{array}{l}-6.703^{* * *} \\
(1.604)\end{array}$ \\
\hline SRISK & $\begin{array}{l}-3.75 \mathrm{e}-05^{* * *} \\
(7.76 \mathrm{e}-06)\end{array}$ & $\begin{array}{l}-4.74 \mathrm{e}-05^{* * *} \\
(1.28 \mathrm{e}-05)\end{array}$ & $\begin{array}{l}-0.000297^{* * *} \\
(3.09 \mathrm{e}-05)\end{array}$ & $\begin{array}{l}-3.76 \mathrm{e}-05^{* * *} \\
(7.79 \mathrm{e}-06)\end{array}$ & $\begin{array}{l}-4.77 \mathrm{e}-05^{* * *} \\
(1.27 \mathrm{e}-05)\end{array}$ & $\begin{array}{l}-0.000295^{* * *} \\
(3.09 \mathrm{e}-05)\end{array}$ \\
\hline LVG & $\begin{array}{l}-0.0977 * * * \\
(0.00580)\end{array}$ & $\begin{array}{l}-0.0883^{* * *} \\
(0.00774)\end{array}$ & $\begin{array}{l}-0.0860^{* * *} \\
(0.0167)\end{array}$ & $\begin{array}{l}-0.0972^{* * *} \\
(0.00581)\end{array}$ & $\begin{array}{l}-0.0868 * * * \\
(0.00776)\end{array}$ & $\begin{array}{l}-0.0890^{* * *} \\
(0.0170)\end{array}$ \\
\hline G-SIB FE & $\begin{array}{l}6.589^{* * * *} \\
(0.613)\end{array}$ & $\begin{array}{l}-0.771 \\
(0.952)\end{array}$ & $\begin{array}{l}-2.921 \\
(1.904)\end{array}$ & $\begin{array}{l}6.604^{* * * *} \\
(0.614)\end{array}$ & $\begin{array}{l}-0.728 \\
(0.954)\end{array}$ & $\begin{array}{l}-2.950 \\
(1.906)\end{array}$ \\
\hline G-SIB & $\begin{array}{l}1.312^{*} \\
(0.709)\end{array}$ & $\begin{array}{l}11.65^{* * *} \\
(1.592)\end{array}$ & $\begin{array}{l}43.23^{* * *} \\
(4.204)\end{array}$ & $\begin{array}{l}1.266^{*} \\
(0.707)\end{array}$ & $\begin{array}{l}11.52^{* * *} \\
(1.584)\end{array}$ & $\begin{array}{l}43.29^{* * *} \\
(4.212)\end{array}$ \\
\hline CISS & $\begin{array}{l}2.452 \\
(1.549)\end{array}$ & $\begin{array}{l}1.395 \\
(2.619)\end{array}$ & $\begin{array}{l}10.55 \\
(6.966)\end{array}$ & $\begin{array}{l}2.950 * \\
(1.557)\end{array}$ & $\begin{array}{l}2.760 \\
(2.619)\end{array}$ & $\begin{array}{l}9.959 \\
(7.008)\end{array}$ \\
\hline Market Return & $\begin{array}{l}97.29 \\
(100.0)\end{array}$ & $\begin{array}{l}-52.24 \\
(158.1)\end{array}$ & $\begin{array}{l}-233.9 \\
(395.5)\end{array}$ & $\begin{array}{l}90.91 \\
(100.2)\end{array}$ & $\begin{array}{l}-69.30 \\
(158.1)\end{array}$ & $\begin{array}{l}-213.3 \\
(395.4)\end{array}$ \\
\hline ST interest rates & $\begin{array}{l}-0.0218 \\
(0.101)\end{array}$ & $\begin{array}{l}0.0805 \\
(0.136)\end{array}$ & $\begin{array}{l}-1.102^{* * *} \\
(0.277)\end{array}$ & $\begin{array}{l}-0.0446 \\
(0.102)\end{array}$ & $\begin{array}{l}0.0188 \\
(0.137)\end{array}$ & $\begin{array}{l}-1.051 * * * \\
(0.274)\end{array}$ \\
\hline ECB Mon.policy Assets & $\begin{array}{l}1.32 \mathrm{e}-06^{* * *} \\
(3.65 \mathrm{e}-07)\end{array}$ & $\begin{array}{l}-2.77 e-07 \\
(6.08 \mathrm{e}-07)\end{array}$ & $\begin{array}{l}6.43 \mathrm{e}-08 \\
(1.74 \mathrm{e}-06)\end{array}$ & $\begin{array}{l}1.37 e-06 * * * \\
(3.65 e-07)\end{array}$ & $\begin{array}{l}-1.53 e-07 \\
(6.10 e-07)\end{array}$ & $\begin{array}{l}8.78 \mathrm{e}-08 \\
(1.75 \mathrm{e}-06)\end{array}$ \\
\hline MV (centered) & $\begin{array}{l}-0.390 * \\
(0.217)\end{array}$ & $\begin{array}{l}0.806^{* *} \\
(0.333)\end{array}$ & $\begin{array}{l}3.966^{* * *} \\
(0.772)\end{array}$ & $\begin{array}{l}-0.994 * * * \\
(0.374)\end{array}$ & $\begin{array}{l}-0.837^{*} \\
(0.506)\end{array}$ & $\begin{array}{l}5.095^{* * *} \\
(0.975)\end{array}$ \\
\hline IRBA-S/F & $\begin{array}{l}0.710 \\
(0.666)\end{array}$ & $\begin{array}{l}0.367 \\
(1.435)\end{array}$ & $\begin{array}{l}-15.88^{* * *} \\
(5.396)\end{array}$ & $\begin{array}{l}0.487 \\
(0.665)\end{array}$ & $\begin{array}{l}-0.245 \\
(1.426)\end{array}$ & $\begin{array}{l}-15.58^{* * *} \\
(5.418)\end{array}$ \\
\hline IRBA-A/M & $\begin{array}{l}5.254^{* * *} \\
(0.696)\end{array}$ & $\begin{array}{l}14.64 * * * \\
(1.483)\end{array}$ & $\begin{array}{l}5.451 \\
(5.617)\end{array}$ & $\begin{array}{l}5.145^{* * *} \\
(0.701)\end{array}$ & $\begin{array}{l}14.36^{* * *} \\
(1.488)\end{array}$ & $\begin{array}{l}6.132 \\
(5.668)\end{array}$ \\
\hline IRBA-S/F \# MV & & & & $\begin{array}{l}1.292^{* * *} \\
(0.469)\end{array}$ & $\begin{array}{l}3.546^{* * *} \\
(0.697)\end{array}$ & $\begin{array}{l}-1.566 \\
(1.546)\end{array}$ \\
\hline IRBA-A/M \# MV & & & & $\begin{array}{l}0.399 \\
(0.503)\end{array}$ & $\begin{array}{l}1.021 \\
(0.798)\end{array}$ & $\begin{array}{l}-2.565 \\
(2.089)\end{array}$ \\
\hline Jan1996- Jun2006 & $\begin{array}{l}1.729^{*} \\
(0.927)\end{array}$ & $\begin{array}{l}1.985^{*} \\
(1.187)\end{array}$ & $\begin{array}{l}-1.292 \\
(1.628)\end{array}$ & $\begin{array}{l}2.127^{* *} \\
(0.957)\end{array}$ & $\begin{array}{l}3.068^{* *} \\
(1.226)\end{array}$ & $\begin{array}{l}-2.037 \\
(1.687)\end{array}$ \\
\hline Jun2006- Sep2008 & $\begin{array}{l}4.817^{* * *} \\
(1.279)\end{array}$ & $\begin{array}{l}6.449 * * * \\
(2.148)\end{array}$ & $\begin{array}{l}26.28^{* * *} \\
(6.254)\end{array}$ & $\begin{array}{l}4.709 * * * \\
(1.289)\end{array}$ & $\begin{array}{l}6.130^{* * *} \\
(2.165)\end{array}$ & $\begin{array}{l}25.79 * * * \\
(6.286)\end{array}$ \\
\hline Sep2008- Sep2010 & $\begin{array}{l}3.754^{* *} \\
(1.470)\end{array}$ & $\begin{array}{l}5.633^{* *} \\
(2.402)\end{array}$ & $\begin{array}{l}26.19 * * * \\
(6.926)\end{array}$ & $\begin{array}{l}4.218^{* * *} \\
(1.496)\end{array}$ & $\begin{array}{l}6.891^{* * *} \\
(2.431)\end{array}$ & $\begin{array}{l}25.24^{* * *} \\
(6.986)\end{array}$ \\
\hline Sep2010- Nov2014 & $\begin{array}{l}4.137^{* * *} \\
(1.363)\end{array}$ & $\begin{array}{l}5.038 * * \\
(2.161)\end{array}$ & $\begin{array}{l}27.84^{* * *} \\
(6.249)\end{array}$ & $\begin{array}{l}4.654 * * * \\
(1.396)\end{array}$ & $\begin{array}{l}6.442^{* * *} \\
(2.202)\end{array}$ & $\begin{array}{l}26.79 * * * \\
(6.345)\end{array}$ \\
\hline Nov2014- Dec2018 & $\begin{array}{l}2.918^{* *} \\
(1.467)\end{array}$ & $\begin{array}{l}4.511^{*} \\
(2.326)\end{array}$ & $\begin{array}{l}26.87^{* * *} \\
(6.609)\end{array}$ & $\begin{array}{l}3.361 * * \\
(1.488)\end{array}$ & $\begin{array}{l}5.713^{* *} \\
(2.358)\end{array}$ & $\begin{array}{l}25.93^{* * *} \\
(6.692)\end{array}$ \\
\hline Country Effects & yes & yes & yes & yes & yes & yes \\
\hline Constant & $\begin{array}{l}6.935^{* * *} \\
(1.244)\end{array}$ & $\begin{array}{l}18.37 * * * \\
(1.803)\end{array}$ & $\begin{array}{l}-1.875 \\
(3.309)\end{array}$ & $\begin{array}{l}6.363^{* * *} \\
(1.281)\end{array}$ & $\begin{array}{l}16.81^{* * *} \\
(1.852)\end{array}$ & $\begin{array}{l}-0.774 \\
(3.410)\end{array}$ \\
\hline Observations & 7489 & 7489 & 7489 & 7489 & 7489 & 7489 \\
\hline Number of banks & 99 & 99 & 99 & 99 & 99 & 99 \\
\hline R-squared & 0.339 & 0.435 & 0.582 & 0.340 & 0.437 & 0.582 \\
\hline RMSE & 13.89 & 21.36 & 50.26 & 13.88 & 21.32 & 50.26 \\
\hline Percentile & 10.00 & 21.13 & 46.19 & 10.00 & 21.13 & 46.19 \\
\hline Norm.RMSE & 1.389 & 1.011 & 1.088 & 1.388 & 1.009 & 1.088 \\
\hline
\end{tabular}

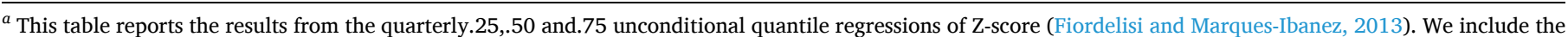

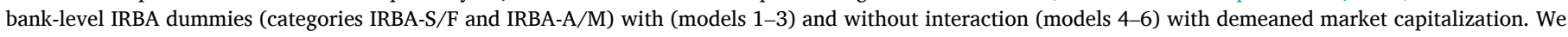

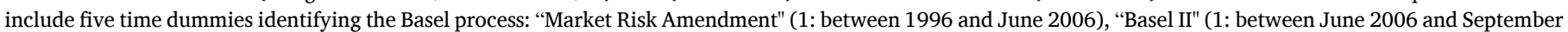

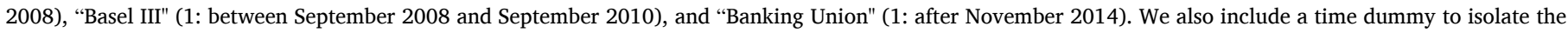

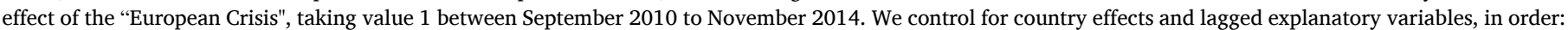

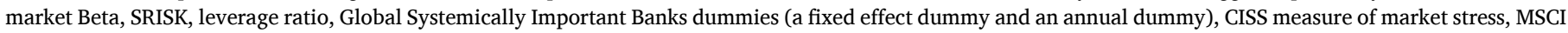

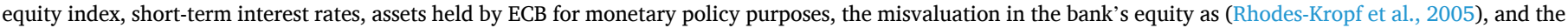
demeaned market capitalization. Robust standard errors in parentheses. ${ }^{* * *} \mathrm{p}<0.01,{ }^{* *} \mathrm{p}<0.05,{ }^{*} \mathrm{p}<0.1$.

reported here. ${ }^{27}$ This evidence stands in stark contrast to the original goals of the Basel Committee in strengthening the safety and soundness of the whole banking system.

In sum, we find no evidence that the introduction of internal models introduced in 2006 did succeed in increasing bank resiliency. The discretion given to the regulated banks apparently, while in compliance

\footnotetext{
${ }^{27}$ The Appendix reports some of these results. In particular, it reports the results from the quantile regression of Delta CoVaR in Table 12 with a similar main result: mixed and advanced IRB models contribute positively to systemic risk exposure across the whole distribution.
}

with regulation, did not stop banks from engaging in (sophisticated) risk-taking activities. ${ }^{28}$

Our results agree well with the findings of Behn et al. (2016b), which was conducted only for German banks. We take a European perspective and relate the impact of credit risk models to the impact of market risk models. It turns out that market risk models had a small but stabilizing effect in contrast to credit risk models. Taking a distributional approach, we find that the risk-enhancing effect of internal models for credit risk

\footnotetext{
28 The next Section 5 aims at showing the robustness of these results in a counterfactual analysis.
} 


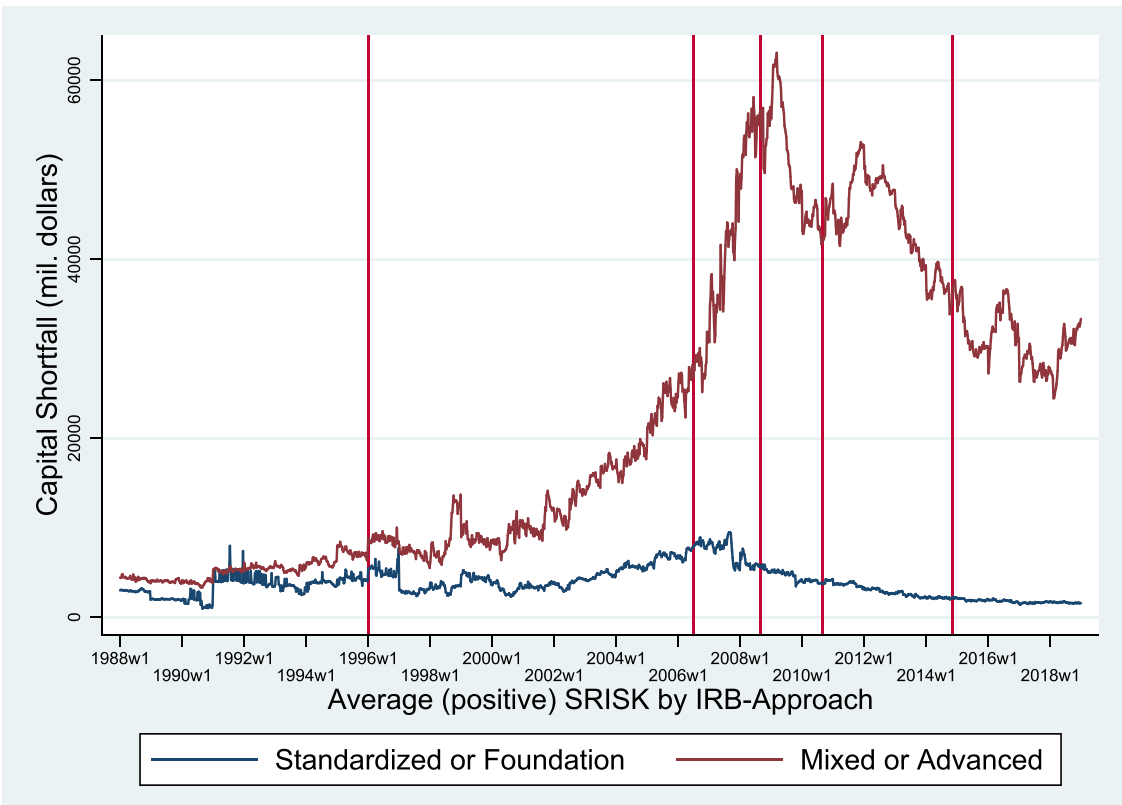

Fig. 6. Credit Risk Internal Models and SRISK. We report the evolution of the daily estimated SRISK (Equation 3), distinguishing for the usage of credit risk internal models (IRBA). We identify banks according to the approach used at the last available date. We distinguish banks applying standardized or foundation approaches (blue line), and banks applying advanced or mixed approaches (red line). (For interpretation of the references to colour in this figure legend, the reader is referred to the web version of this article.) are increasing in the systemical importance of banks; in larger and more systemic banks, internal models contribute more strongly to an increase in SRISK of European banks and across risk classes. Moreover, we find evidence for heterogeneity in the supervisory approach across European countries. Based on our results, the concerns raised about Basel II by Danielson et al. (2001) are validated by the data. By neglecting the endogeneity of systemic risk, Basel II regulation did not succeed to reduce systemic risk precisely in those sectors that turned out to become the most vulnerable ones.

Moreover, the implementation of Basel II in July 2006 has contributed to the build-up of systemic risk with the larger banks contributing even more. This finding contradicts the hypothesis of Hakenes and Schnabel (2011), who on the basis of theoretical considerations argue that the IRB-approach of Basel II induces smaller and medium-sized banks to take larger risks in order to compete more effectively with larger banks employing the IRB-approach. We find that their basic assumption that IRB contributes positively to larger banks is not supported by the data. ${ }^{29}$

In summary, the intended consequences of the Basel regulation were achieved only for the safer banks, but, ironically, they were missed out for the riskier banks. Obviously, banks' strategic incentives were not properly understood and the substitutability between capital rules and state guarantees was seriously underestimated throughout the various stages of the Basel process. Consequently, it was especially the systemically important European banks that were ill prepared to deal with the subprime crisis in 2007 and even more in the subsequent European sovereign crisis. These unbalanced developments across the crosssection of banks continue to hold even under the ongoing Basel III reforms that arguably focus more on macro-prudential concerns.

\footnotetext{
${ }^{29}$ Even if the competitive effect of Hakenes and Schnabel (2011) is relevant at all, our evidence suggests that the direct (negative) implications for banks' risk management are dominant. However, our findings about the effects of internal models suggest that the assumption of an increase in resiliency or the largest banks due to the use of risk-models is not supported by the data. In this regard, also (Colliard, 2015) has investigated theoretically the impact of internal models on the risk-taking behaviour of banks.
}

\subsection{Sources of individual bank risk}

Since it has often been argued that, pre-crisis, the Basel process was focused on micro-prudential regulation targeted towards individual bank risk rather than macro-prudential concerns, it may seem instructive to analyse individual bank failure risk on its own, rather than systemic risk. The evolution of the trajectories of Z-score across different risk classes of banks already indicates that it might be illuminating to analyze the policy effects on individual bank risk by means of quantile regressions as well. Table 2 reports the results of the quantile regressions of Z-score.

As in our analysis of systemic risk in the previous section, we find differential effects of policy variables across the cross-section of banks, although the differences seem less pronounced. While market risk models (Jan1996-Jun2006) did increase resiliency at the lower riskiest quartile, the effect in the highest safest quartile are insignificant. Likewise, the other time dummies show an improvement in resiliency over the Basel process across the riskiest banks in the lowest quantile.

Looking at the internal model implementation, we observe a similar decrease in insolvency risk among the riskiest banks if internal models are used. The aggressive mixed and advanced credit risk models (IRBA$\mathrm{A} / \mathrm{M}$ ) contributed to increase the resiliency in the riskiest quartiles at the average size firm. On the other hand, the passive models (IRBA-S/F) are related to increased insolvency risk in the largest safest quartile, while it is related to higher resiliency for the largest and safest banks in the lower quartiles. Moreover, the G-SIB-capital surcharges contribute positively to enhancing resiliency across the full cross-section.

The standard bank characteristics are related to insolvency risk as expected. Leverage (LVG) enhances insolvency risk across all quartiles. Moreover, country are strong and significant.

Interestingly, the correlation with interest rates (ST interest rates) is ambiguous across the distribution. The level of interest rates is negatively related to resiliency in the highest quartile, while it is insignificant in the lower quartile. This implies that a low interest rate monetary policy is positively related to the resiliency of the already safest banks in the upper quartiles, but is unrelated in the lowest quartiles of risky institutions. Asset purchases (ECB Mon.policy Asset), on the other hand, correlate positively with the resiliency of the already risky banks in the lowest quartile. 
Table 3

PSM and difference-in-differences.

\begin{tabular}{|c|c|c|c|c|c|}
\hline A.PROBIT PSM & (1) & (2) & (3) & (4) & (5) \\
\hline L.SRISK & $\begin{array}{l}-0.00000438^{* * *} \\
(0.0000)\end{array}$ & $\begin{array}{l}-0.00000325^{*} \\
(0.0000)\end{array}$ & $\begin{array}{l}-0.000021 * * * \\
(0.0000)\end{array}$ & $\begin{array}{l}-0.0000035^{*} \\
(0.0000)\end{array}$ & $\begin{array}{l}-0.0000185^{* * *} \\
(0.0000)\end{array}$ \\
\hline Beta & $\begin{array}{l}0.26498^{* * *} \\
(0.0202)\end{array}$ & $\begin{array}{l}0.1413^{* * *} \\
(0.0217)\end{array}$ & $\begin{array}{l}0.2331 * * * \\
(0.0187)\end{array}$ & $\begin{array}{l}0.14207^{* * *} \\
(0.0217)\end{array}$ & $\begin{array}{l}0.0067453 \\
(0.0244)\end{array}$ \\
\hline Z-score & $\begin{array}{l}-0.0060^{* * *} \\
(0.0004)\end{array}$ & $\begin{array}{l}-0.0045^{* * *} \\
(0.0004)\end{array}$ & $\begin{array}{l}-0.0016^{* * *} \\
(0.0003)\end{array}$ & $\begin{array}{l}-0.00458^{* * *} \\
(0.0004)\end{array}$ & $\begin{array}{l}-0.0034628^{* * *} \\
(0.0004)\end{array}$ \\
\hline LVG & $\begin{array}{l}0.01008^{* * *} \\
(0.0004)\end{array}$ & $\begin{array}{l}0.0096 * * * \\
(0.0005)\end{array}$ & $\begin{array}{l}0.00696 * * * \\
(0.0004)\end{array}$ & $\begin{array}{l}0.0095^{* * *} \\
(0.0005)\end{array}$ & $\begin{array}{l}0.0029 * * * \\
(0.0004)\end{array}$ \\
\hline MV & $\begin{array}{l}0.000068^{* * *} \\
(0.0000)\end{array}$ & $\begin{array}{l}0.000072^{* * * *} \\
(0.0000)\end{array}$ & $\begin{array}{l}0.000071^{* * *} \\
(0.0000)\end{array}$ & $\begin{array}{l}0.000072^{* * *} \\
(0.0000)\end{array}$ & $\begin{array}{l}0.000072^{* * *} \\
(0.0000)\end{array}$ \\
\hline Misvaluation & $\begin{array}{l}-0.0025 \\
(0.0115)\end{array}$ & $\begin{array}{l}0.03091 * * * \\
(0.0120)\end{array}$ & $\begin{array}{l}-0.08305^{* * *} \\
(0.0100)\end{array}$ & $\begin{array}{l}0.0303^{* *} \\
(0.0120)\end{array}$ & $\begin{array}{l}0.01989 * \\
(0.0118)\end{array}$ \\
\hline CISS & & & $\begin{array}{l}0.1534 \\
(0.1336)\end{array}$ & $\begin{array}{l}0.1247 \\
(0.1920)\end{array}$ & $\begin{array}{l}1.26382^{* * *} \\
(0.1718)\end{array}$ \\
\hline Market Return & & & $\begin{array}{l}0.0356 \\
(1.4153)\end{array}$ & $\begin{array}{l}-0.0332 \\
(1.5724)\end{array}$ & $\begin{array}{l}-0.3734178 \\
(1.7704)\end{array}$ \\
\hline ST interest rates & & & $\begin{array}{l}0.0774 * * * \\
(0.0029)\end{array}$ & $\begin{array}{l}0.0063 * * * \\
(0.0049)\end{array}$ & $\begin{array}{l}0.01483^{* *} \\
(0.0066)\end{array}$ \\
\hline ECB monetary policy assets & & & $\begin{array}{l}-0.00000031 * * * \\
(0.0000)\end{array}$ & $\begin{array}{l}-0.000002^{* * *} \\
(0.0000)\end{array}$ & $\begin{array}{l}0.0000015^{* * *} \\
(0.0000)\end{array}$ \\
\hline HUR & & & & & $\begin{array}{l}0.15646^{* * *} \\
0.0045239\end{array}$ \\
\hline PPI & & & & & $\begin{array}{l}-0.0217^{* * *} \\
0.0038617\end{array}$ \\
\hline QGDP & & & & & $\begin{array}{l}0.0209935 \\
0.0153126\end{array}$ \\
\hline Constant & $\begin{array}{l}-0.2299 * * * \\
(0.0318)\end{array}$ & $\begin{array}{l}0.21091^{* * *} \\
(0.0710)\end{array}$ & $\begin{array}{l}-0.50355^{* * *} \\
(0.0291)\end{array}$ & $\begin{array}{l}0.1683^{* *} \\
(0.0795)\end{array}$ & $\begin{array}{l}-2.0087 * * * \\
(0.0596)\end{array}$ \\
\hline Country effects & yes & yes & no & yes & no \\
\hline Year effects & no & yes & no & yes & no \\
\hline Number of observations & 36,175 & 36,175 & 40,568 & 36,111 & 22,801 \\
\hline Pseudo R2 & 0.2601 & 0.2766 & 0.1715 & 0.277 & 0.1607 \\
\hline $\begin{array}{l}\text { B.DIFF.-IN-DIFFERENCES } \\
\text { Before } 2006\end{array}$ & (1) & $(2)$ & (3) & (4) & (5) \\
\hline Control & 7859 & 12,703 & 6707 & 12,820 & 8054 \\
\hline Treated & 4541 & 4336 & 6176 & 4341 & 6135 \\
\hline Diff $(T-C)$ & $\begin{array}{l}-3318 \\
(6118.19)\end{array}$ & $\begin{array}{l}-8367 \\
(9047.51)\end{array}$ & $\begin{array}{l}-531 \\
(5058.25)\end{array}$ & $\begin{array}{l}-8479 \\
(9082.11)\end{array}$ & $\begin{array}{l}-1919 \\
(5538.00)\end{array}$ \\
\hline After 2006 & & & & & \\
\hline Control & 7631 & 2987 & 3083 & 2189 & 2180 \\
\hline Treated & 17,599 & 24,448 & 29,423 & 20,834 & 27,409 \\
\hline Diff (T-C) & $\begin{array}{l}9968 \\
(7420.37)\end{array}$ & $\begin{array}{l}21,461^{* * *} \\
(7505.99)\end{array}$ & $\begin{array}{l}26,340 * * * \\
(6892.16)\end{array}$ & $\begin{array}{l}18,645^{* * *} \\
(6054.69)\end{array}$ & $\begin{array}{l}25,229 * * * \\
(6986.00)\end{array}$ \\
\hline Diff-in-Diff & $\begin{array}{l}13,286.01^{* * *} \\
(4527.87)\end{array}$ & $\begin{array}{l}29,828.56^{* * *} \\
(9891.47)\end{array}$ & $\begin{array}{l}26,870.61^{* * *} \\
(6912.34)\end{array}$ & $\begin{array}{l}27,124.21^{* * *} \\
(9666.79)\end{array}$ & $\begin{array}{l}27,148.290^{* * * *} \\
(7856.176)\end{array}$ \\
\hline Number of observations & 70388 & 70433 & 84233 & 69718 & 69,937 \\
\hline R-square & 0.056 & 0.099 & 0.14 & 0.108 & 0.122 \\
\hline
\end{tabular}

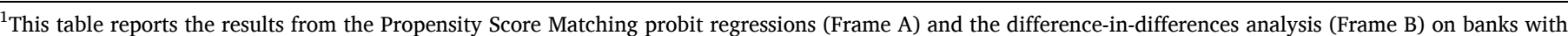

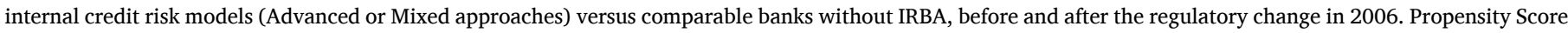

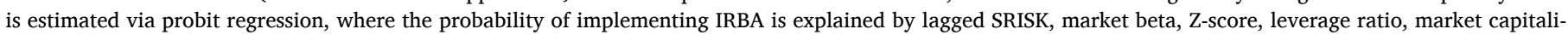

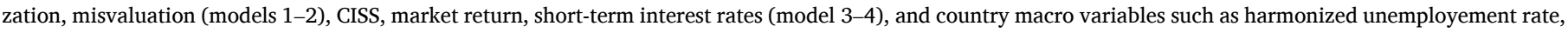
PPI, and quarterly GDP growth (model 5). We report robust standard errors, clustered per firm. $* * * 0.01 ; * * 0.05 ; * 0.10$.

\subsection{The Basel process}

In summary, our findings both on systemic and individual banking risk are rather mixed. While internal models benefit the less risky banks in our sample in terms of idiosyncratic resiliency, they contribute to reducing the perceived stability of the systemically important banks. Overall, it is fair to say that we cannot find evidence in favor of internal credit risk models contributing to a general increase in safety and soundness of the European banking system.

Moreover, our results also provide a mixed picture about the overall effect of the Basel process on bank resiliency. This is true both on the dimension of micro-prudential concerns, measured by z-score, as well as on macro-prudential concerns, measured by capital shortfall SRISK. By way of summarizing, the Basel process has been rather successful in enhancing the resiliency of the less risky banks, both in terms of individual insolvency risk as well as in terms of exposure to systemic risk. However, the account is quite different for the most risky banks. Our analysis suggests that even early policy measures such as the market risk amendment as well as, and in particular, the extension of internal model for credit risk are associated with a decrease of resiliency, both in terms of individual banking risk as well as systemic risk. On the other hand, the G-SIB capital surcharges of Basel III tend to be related positively to resiliency.

As a byproduct of our analysis we also find that the introduction of Banking Union as well as instruments of monetary policy differentially exert stronger correlations with capital shortfall of systemic banks relative to less systemic banks.

\section{The role of internal credit risk models}

As we have seen in the previous section, advanced internal models are strongly correlated with capital shortfall. Therefore, it seems important to investigate the risk measures around the implementation date. We apply a difference-in-differences approach in conjunction with 
propensity score matching to estimate the contribution of IRBA models on the systemic risk exposure of the banks opting for the internal model approach. More specifically, we consider treatment as the implementation of IRBA for credit risk, so that treated banks are those that use either foundation or mixed/advanced internal models, while the untreated banks are the ones applying the standardized regulatory approach. We apply a propensity score matching in order to assign comparable control banks to each treated institution.

A naive parallel comparison of SRISK is shown in Fig. 6. We observe how banks that opted for advanced or mixed IRBA after 2006 (IRBA-A/ M) always had a higher level of SRISK. However, their systemic risk exposure sharply increases after Basel II allows them to use IRBA. ${ }^{30}$ Applying a difference-in-differences analysis, we discriminate between treated versus control banks, before and after Basel II implementation on June 2006.

In order to estimate the counterfactual and reduce the selection bias, we identify a control group by kernel propensity score matching method (Rosenbaum et al., 1983). Based on the above observations we run a probit regression to estimate the probability of implementing IRBA models given a set of observable characteristics and assign a propensity score to balance the treated and the comparison groups. We will therefore use these variables as observable characteristics to match treated versus untreated firms, besides the explanatory variables we used in the previous section (lagged SRISK, Z-score, leverage ratio, market misvaluation and macro variables). ${ }^{31}$

Thus, we estimate a difference-in-differences weighted regression, where observations are weighted to ensure that each group reflects the covariate distribution in the pre-Basel II period. The outcome variable is SRISK, and we include the covariates we have previously found as important drivers of SRISK:

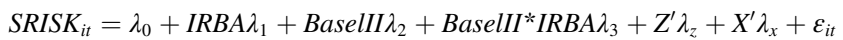

where IRBA is the dummy variable identifying banks with advanced or mixed credit risk internal models, Basel II is the time dummy capturing changes after the implementation of Basel II, and Basel II * IRBA is the interaction term identifying IRBA banks after June 2006. $X_{t}$ and $Z_{i t}$ include the bank and market regressors as in previous Section.

The difference-in-differences parameter is therefore:

$\widehat{\sigma_{3}}=\left(\overline{S R I S K}_{I R B A, p o s t}-\overline{\operatorname{SRISK}}_{\text {IRBA,pre }}\right)-\left(\overline{\operatorname{SRISK}}_{\text {nonIRBA }, \text { post }}-\overline{\operatorname{SRISK}}_{\text {nonIRBA,pre }}\right)$

This method allows us to remove both potential biases in the postBasel period between the treated and the control groups that could result from permanent differences between banks, and potential biases from comparisons over time in the treatment group that could result from other changes.

We report the results on the mean regression. The treated group comprises banks that did implement internal credit risk models after the regulatory option is made available by Basel II in June 2006. Table 3

\footnotetext{
30 The seemingly strange pattern of foundation-IRBA is due to the fact that banks entered gradually into internal modelling, therefore the foundation approach was a first intermediate step for banks that consequently moved on to implement advanced approaches.

${ }^{31}$ Further support for our choice of propensity score matching is provided by the change in business models incentivized by Basel II. Because of data limitations in SNL bank coverage, we have to restrict our analysis to observations from 2005 onwards, and we do not report the results. Scrutinizing bank characteristics, we observe that banks that use a mixed or advanced approach tend to be the largest firms in terms of Tier-1 capital. However, at the same time they exhibit the strongest increase in their non-performing loans ratios, while, seemingly paradoxically, holding the lowest level of total equity. In terms of risk weights their trajectory follows closely the trajectory of banks with the standardized approach after 2010.
}

reports the results for the probit regression for the PSM (frame A) and the difference-in-differences estimation (frame B). The bankcharacteristics that were used before throughout our analysis appear to importantly affect the choice of implementing internal models, in line with the probit regression results in frame A.

The propensity score method provides the weights for the weighted difference-in-differences regression. The results strongly support our hypothesis that exposure to systemic risk is strongly associated to the use of internal credit risk models. While there are no significant differences in SRISK between treatment and control groups prior to the implementation of Basel II standards, we find strong and significant differences in risk exposure after their introduction in 2006. In the follow-up period, we see that institutions that have chosen to implement credit risk models as either advanced or mixed approaches, have increased significantly more in exposure to systemic risk in the post-Basel II period compared to the peer group.

\section{Conclusions}

We document a steady increase in the systemic risk exposure of European banks as measured by the capital shortfall measure SRISK within the past 30 years. While aggregate capital shortfall in the $1990 \mathrm{~s}$ was around $1 \%$ of national GDP it increased to about $4-5 \%$ of Eurozone GDP. This observations runs counter to intensive regulatory attempts to impose a floor on bank capitalization in a long process of regulating minimum capital. Our finding is complemented by the observation that virtually all commonly known systemic risk measures (e.g. those reported by Giglio et al., 2016)) are upward trending over this period despite the fact that measures of individual banking risk such as z-score suggest a reduction in (individual) banking risk. The lion's share of the increase in systemic risk occurs in the highest quintile of the size distribution of banks. For almost half of the banks in our sample, and certainly for the lower two quintiles, the various risk measures are increasing moderately or even remain roughly constant over the past 30 years.

While the Basel process of capital regulation was designed to increase the stability and safety of the global banking system, our empirical evidence robustly suggests that it did not achieve this goal in its first three decades of operation for European banks. From the perspective of systemic risk measures, the Basel process has been more effective for smaller banks. But even there it did not significantly reduce systemic exposures or contagion risk. For the largest quantiles of banks, internal models might have provided strong incentives to carve out equity and, thus, reduce in-house resiliency. The evidence demonstrates that those incentives had been exploited and the resiliency of large and systemically important European banks had already become greatly impaired at the onset of the Great Financial Crisis. To the extent that most of the largest banks did engage in this activity of reducing their capital buffers, overall bank capital became scarce, generating systemic concerns for the whole banking sector. But even 10 years later most individual - and thus also aggregate - SRISK scores did not retreat to precrises levels or even below. $^{32}$

\footnotetext{
${ }^{32}$ This observation is consistent with attempts of ECB researchers (Homar et al., 2016) trying to empirically validate the ECB policy of focusing in particular on the European ECB and EBA stress scenarios rather than focusing on individual and aggregate capital shortfall for the Euro area as suggested by Acharya et al. (2014).
} 
Controlling for balance sheet variables, the standard drivers of bank stock prices and macroeconomic indicators, ${ }^{33}$ our structural analysis of the drivers of SRISK strongly suggests that internal risk models were chosen strategically. Similar results have been derived by Behn et al. (2016b) on a sample of German banks and (Colliard, 2015). The strategic use of internal models is one major source of the depletion of bank equity (Admati and Hellwig, 2013). Ironically, these equity carve-outs were one way of increasing return on equity through extensive stock repurchases prior to the Great Financial Crisis at a time when the cost of bank equity was actually low, and strengthening capitalization and resiliency would have been relatively cheap (in historical context). ${ }^{34}$ This observation may simply constitute a reflection of the leverage ratchet effect (see Admati et al., 2018).

On the basis of our analysis it is not necessarily that capital rules per se were insufficient; it is rather the possibility to reduce effective capitalization by means of complex risk models under supervisory approval that causes the lack of resiliency. Our findings accord well with (Miles et al., 2012). They seem to contradict Jackson (2015) in the sense that simple models, even at sub-optimal levels in terms of efficiency, may be more suitable to limit risks and, hence, safeguard resiliency.

While the political support for the use of internal models still is unbroken in Europe, the heated debate on the conclusion of Basel III also reflects the need for a more critical perspective on self-regulatory instruments, and, hence, the need of limiting their potential misuse. The Basel Committee's Consultative Document on credit risk models (Basel Committee on Banking Supervision, 2016) explicitly proposes to remove this self-regulatory option for exposures that do not allow for sufficiently reliable estimates, such as low-default exposures. This recommendation accords well with our empirical findings presented above. Surprisingly, in finalizing the Basel III agreement it was the European supervisors who were reluctant in curbing the use of mixed and advanced IRBA-models, while the original proponents of internal models under Basel II, namely the U.S. tried to phase them out. ${ }^{35}$

We also suggest that, by concentrating on formal fulfilment of regulatory rules based on book values, regulators missed a pro-social role in interpreting (negative) market feedback. Relying on rules based on book values only, neglects social feedback and market expectations. However, trust and confidence are key in the banking industry, but they are notoriously difficult to measure. Hence, market-based risk measures are one simple step towards taking into account market reactions, trust and confidence, and hence systemic market feedback. This is potentially crucial information and supervisors should be challenged to explain more when and why they disregard market information. ${ }^{36}$ After all, supervision plays an important role to correct potential misbehavior

\footnotetext{
33 While we cannot completely rule out omitted variables, we make a large attempt to include all the known drivers of stock prices that crucially affect our endogenous variable SRISK plus additional country-specific macro-economic indicators. Moreover, the cross-sectoral heterogeneity does contribute importantly to identifying causal relationships between regulatory variables and SRISK. In addition we perform both a counter-factual simulation and a difference-in-differences analysis.

34 Baron and Xiong (2014) provide a behavioural explanation based on over-optimism.

35 The conclusion of Basel III at the Santiago de Chile Summit in November 2016 failed because of disagreement about the proper output floor. While the U. $\mathrm{S}$. insisted on a minimal role for internal models with an output floor of above $80 \%$ the European supervisors pushed for an output floor of below $70 \%$. The output floor provides a limit by which internal models can undercut the risk weights implied by the standard approach. In November 2017 a compromise was found at an output floor of $72.5 \%$.

36 This argument is not saying that there is no mispricing in markets. However, under normal conditions mispricing should be a short-term problem. In the long run markets should converge to fair valuations. For example, a marketto-book anomaly may occur for short periods; but when it persists for years or decades, the underlying sources of the anomaly may be important to remedy.
}

only in market economies. This argument assumes the existence of a sufficiently high degree of trust in the operation of markets after all. If this trust cannot be assured in normal periods, why not economize on bureaucracy and centralize the whole banking system?

Our analysis also uncovers disconcerting effects of monetary policy on banks' contribution to systemic risk. This is particularly true for the less risky and typically smaller banks. Hence, we empirically verify that a low-growth environment creates incentives for risk-taking, and, therefore, an increase both in contagion risk and exposure to systemic risk. Accordingly, under the current regulatory framework, quantitative easing, through its effect on interest rates, contributes to undermining the stability and soundness of the European banking system. ${ }^{37}$ Interestingly, these concerns do not affect the most systematically risky banks, which are tightly supervised in the first place.

There are even wider implications of the Basel process of capital regulation beyond the banking industry on the whole financial sector. For example, the build-up of systematic risk in the insurance sector (Gehrig and Iannino, 2018), while not as dramatic as in the banking sector, also significantly moves upwards with a structural break around 1996. Possibly these developments also exhibit unintended consequences across markets and industries: long-term lending is increasingly given up by banks ${ }^{38}$ and taken over by the insurance sector. Hence, a final evaluation of the welfare consequences of the Basel process of capital regulation requires an analysis of the whole financial sector in order to not only account for market feedback, both in the regulated as well as the unregulated segments, but also for substitution effects and their implications on complementary activities. We leave this for future research.

We also leave for future research the interaction between capital regulation and Banking Union. It is too early for a final judgement of Banking Union on the most systemic banks. However, at this stage we cannot detect any decline in the systemic risk scores for the banks under direct ECB supervision. Certainly, their SRISK remain well above the 2008 levels still ten years later in 2018.

It will be most interesting to compare the evolution of capital shortfall of European banks with their US counterparts, which after hefty forced re-capitalization now tend to be highly profitable, dominating the global league tables again (Kuls, 2018). It may not come as a surprise to find that adequate capitalization in general also confers competitive advantage in global markets similar in spirit to the experience of the successful European turnarounds.

A robust recommendation suggested by our work for policy makers and supervisors implies that all attempts to fix the capital shortfall and, hence, exposure to systemic risk of European banks have not been determined enough so far as to rebuild pre-crisis resiliency. In this sense, the pointed warning of John Vickers (Vickers, 2017) about the still dangerously high level of leverage extends well from British banks also to the European continent. ${ }^{39}$

\section{Appendix A. Appendix}

\section{Statistics}

(See Table 4-12).

\footnotetext{
37 Our findings suggests that quantitative easing would require complementary supervisory instruments to control adverse risk-taking incentives. In the case of Europe such complementary control was not effective for the period of our study.

38 On the shortening of banks' planing horizon see also (Boot and Ratnovski, 2016).

${ }^{39}$ See the comment in the Financial Times (2018) by Arnold (2018)).
} 
Table 4

Variables.

\begin{tabular}{|c|c|c|c|}
\hline Variable & Frequency & Description and Reference & Database \\
\hline SRISK & Daily & Equation 13 (Brownlees and Engle, 2017; Acharya et al., 2012), where $\mathrm{k}=0.08$. & $\begin{array}{l}\text { Compustat Global, Datastream and } \\
\text { Bundesbank, own calc. }\end{array}$ \\
\hline Delta CoVaR & Daily & Equation 8, estimated by quantile regression and empirical quantile at alpha= 0.05 (Adrian and Brunnermeier, 2017). & $\begin{array}{l}\text { Compustat Global, Datastream and } \\
\text { Bundesbank, own calc. }\end{array}$ \\
\hline Z-score & Quarterly & Equation 15 (Lepetit and Strobel, 2013) & Compustat Global, own calc. \\
\hline Beta & Daily & $\begin{array}{l}\text { Conditional dynamic market beta: } \rho_{i m} . * \sigma_{i} / \sigma_{m} \text {, where } \rho_{\text {im, }} \text {, correlation coefficient between the bank's and the market returns, is estimated by Dynamic } \\
\text { Conditional Correlation model (Engel, 2002), and the volatilities } \sigma \text { are estimated by asymmetric GJR GARCH model (Glosten et al., 1993) }\end{array}$ & $\begin{array}{l}\text { Compustat Global and Datastream, own } \\
\text { calc. }\end{array}$ \\
\hline Market Return & Daily & MSCI Europe index & Datastream \\
\hline Stock return & daily & Bank's log stock return & Compustat Global own calc. \\
\hline Market value & Daily & (stock price * shares outstanding) standardized & Compustat Global, own calc. \\
\hline Market-to-book & Quarterly & Market capitalization/Book equity (Daniel and Titman, 2006) & Compustat Global, own calc. \\
\hline Misvaluation & Quarterly & $\begin{array}{l}\text { Bank's firm misvaluation, estimated as both firm-specific deviation from valuations implied by current sector, and deviations from long-run sector } \\
\text { multiples (Rhodes-Kropf et al., 2005) }\end{array}$ & Compustat Global, own calc. \\
\hline Total Assets & Quarterly & Reported total assets & Compustat Global \\
\hline Total Liabilities & Quarterly & Reported total liabilities & Compustat Global \\
\hline Leverage (LVG) & Quarterly & (Total liabilities + Market capitalization) / Market capitalization & Compustat Global, own calc. \\
\hline Deposits & Annual & Total Deposits / Total liabilities & Compustat Global, own calc. \\
\hline Non-interest income & Annual & Non-interest income / Net Income & Compustat Global, own calc. \\
\hline Non-performing assets & Annual & Non-performing assets / Total assets & Compustat Global, own calc. \\
\hline $\begin{array}{l}\text { Risk-adjusted capital } \\
\text { ratio }\end{array}$ & Annual & Risk-adjusted capital ratio & Compustat Global \\
\hline G-SIB FE & Binary & 1: a global systemically relevant institution as been defined as such at least once by the Financial Stability Board (FSB). & FSB-BCBS, own calc. \\
\hline G-SIB & Annual & 1: bank is included in the list of G-SIBs by the FSB-BCBS & FSB-BCBS, own calc. \\
\hline CISS & Weekly & Market stress indicator (Holló et al., 2012) & ECB and authors \\
\hline $\begin{array}{l}\text { Short Term (ST) interest } \\
\text { rates }\end{array}$ & Monthly & Country interest rates based on three-month money market rates where available, or rates on similar financial instruments & OECD \\
\hline $\begin{array}{l}\text { Long Term (LT) interest } \\
\text { rates }\end{array}$ & Monthly & Country interest rates referring to government bonds maturing in ten years & OECD \\
\hline $\begin{array}{l}\text { ECB monetary policy } \\
\text { assets }\end{array}$ & Annual & Total assets held by the ECB for the asset purchase programmes & ЕСВ \\
\hline $\begin{array}{l}\text { Unemployment rate } \\
\text { (HUR) }\end{array}$ & Monthly & Country Harmonised unemployment rates as a percentage of civilian labour force & OECD \\
\hline $\begin{array}{l}\text { Producer Price Index } \\
\text { (PPI) }\end{array}$ & Monthly & Country PPI, domestic manufacturing, annual growth in percentage & OECD \\
\hline Quarterly GDP (QGDP) & Quarterly & Real GDP (constant prices) adjusted for seasonal influences, in percentage change from the previous quarter & OECD \\
\hline $\begin{array}{l}\text { Number of M\&A per } \\
\text { year }\end{array}$ & Annual & Annual number of mergers\&acquisitions as reported by Compustat Global & Compustat Global, own calc. \\
\hline IRBA & Quarterly & $\begin{array}{l}\text { Internal Rating Based Approach used at bank-level. IRBA_S } / \mathrm{F}=1 \text { : standardized or foundation approaches after June2006; IRBA_A/M= 1: mixed or } \\
\text { advanced approaches after June2006 }\end{array}$ & SNL, central banks \\
\hline Basel I & Binary & 1: before 1996; 0: otherwise & BCBS (July 1998), own calc. \\
\hline $\begin{array}{l}\text { Market Risk } \\
\text { Amendment }\end{array}$ & Binary & 1: 1996-1june2006; 0: otherwise & BCBS (January 1996), own calc. \\
\hline Basel II & Binary & 1: 1 june2006 to 1 sept2008; 0 : otherwise & BCBS (June 2006), own calc. \\
\hline Basel III & Binary & 1: 1sept2008 to 1 sep2010; 0: otherwise & BCBS (September 2008), own calc. \\
\hline $\begin{array}{l}\text { Sovereign European } \\
\text { crisis }\end{array}$ & Binary & 1: 1sep2010 to 1nov2014; 0: otherwise & own calc. \\
\hline Banking Union & Binary & 1: from 1nov2014; 0: otherwise & CR (EU) No 1024/2013, own calc. \\
\hline
\end{tabular}

${ }^{a}$ This table reports detailed information on the data and variables used in the empirical analysis. It refers to the sources of the data and the data providers descriptions, when available. 
Table 5

Correlation matrix.

\begin{tabular}{|c|c|c|c|c|c|c|c|c|c|c|c|c|c|c|c|c|c|c|c|c|c|c|}
\hline & (1) & $(2)$ & (3) & (4) & $(5)$ & (6) & $(7)$ & (8) & (9) & $(10)$ & (11) & (12) & (13) & $(14)$ & $(15)$ & $(16)$ & $(17)$ & $(18)$ & (19) & (20) & $(21)(2$ & \\
\hline (1)SRISK & 1 & & & & & & & & & & & & & & & & & & & & & \\
\hline (2)Beta & $\begin{array}{c}0.395 \\
(0.00)\end{array}$ & 1 & & & & & & & & & & & & & & & & & & & & \\
\hline (3)Delta CoVaR & $\begin{array}{r}0.376 \\
(0.00)\end{array}$ & $\begin{array}{c}0.581 \\
(0.00)\end{array}$ & 1 & & & & & & & & & & & & & & & & & & & \\
\hline (4)Z-score & $\begin{array}{r}-0.035 \\
(0.00)\end{array}$ & $\begin{array}{c}-0.189-0 \\
(0.00)(0\end{array}$ & $\begin{array}{l}0.028 \\
0.00)\end{array}$ & 1 & & & & & & & & & & & & & & & & & & \\
\hline (5)CAPR3 & $\begin{array}{c}0.022 \\
(0.00)\end{array}$ & $\begin{array}{c}-0.097-0 \\
(0.00)(0\end{array}$ & $\begin{array}{l}0.128 \\
0.00)\end{array}$ & $\begin{array}{r}0.18 \\
(0.00)\end{array}$ & 1 & & & & & & & & & & & & & & & & & \\
\hline (6) LVG & $\begin{array}{r}0.211 \\
(0.00)\end{array}$ & $\begin{array}{c}0.0320 \\
(0.00)(0\end{array}$ & $\begin{array}{l}0.108 \\
0.00)\end{array}$ & $\begin{array}{r}0.189 \\
(0.00)\end{array}$ & $\begin{array}{r}0.066 \\
(0.00)\end{array}$ & 1 & & & & & & & & & & & & & & & & \\
\hline (7) CISS & $\begin{array}{r}0.153 \\
(0.00)\end{array}$ & $\begin{array}{c}0.0260 \\
(0.00)(0\end{array}$ & $\begin{array}{l}0.387 \\
0.00)\end{array}$ & $\begin{array}{r}0.062 \\
(0.00)\end{array}$ & $\begin{array}{l}-0.103 \\
(0.00)\end{array}$ & $\begin{array}{r}0.17 \\
(0.00)\end{array}$ & 1 & & & & & & & & & & & & & & & \\
\hline (8) LT interest rates & $\begin{array}{c}-0.154 \\
(0.00)\end{array}$ & $\begin{array}{c}0.0910 \\
(0.00)(0\end{array}$ & $\begin{array}{l}0.057 \\
0.00)\end{array}$ & $\begin{array}{c}-0.34 \\
(0.00)\end{array}$ & $\begin{array}{l}-0.504 \\
(0.00)\end{array}$ & $\begin{array}{l}-0.05 \\
(0.00)\end{array}$ & $\begin{array}{r}-0.016 \\
(0.00)\end{array}$ & 1 & & & & & & & & & & & & & & \\
\hline (9) $\mathrm{ST}$ interest rates & $\begin{array}{c}-0.142 \\
(0.00)\end{array}$ & $\begin{array}{c}-0.085-0 \\
(0.00)(0\end{array}$ & $\begin{array}{l}0.021 \\
0.00)\end{array}$ & $\begin{array}{r}-0.261 \\
(0.00)\end{array}$ & $\begin{array}{r}-0.39 \\
(0.00)\end{array}$ & $\begin{array}{l}-0.157 \\
(0.00)\end{array}$ & $\begin{array}{r}-0.093 \\
(0.00)\end{array}$ & $\begin{array}{c}0.716 \\
(0.00)\end{array}$ & 1 & 1 & & & & & & & & & & & & \\
\hline (10)HUR & $\begin{array}{r}-0.06 \\
(0.00)\end{array}$ & $\begin{array}{c}0.2630 \\
(0.00)(0\end{array}$ & $\begin{array}{l}0.131 \\
0.00)\end{array}$ & $\begin{array}{r}-0.091 \\
(0.00)\end{array}$ & $\begin{array}{l}-0.241 \\
(0.00)\end{array}$ & $\begin{array}{c}0.056 \\
(0.00)\end{array}$ & $\begin{array}{r}-0.08 \\
(0.00)\end{array}$ & $\begin{array}{c}0.37 \\
(0.00)\end{array}$ & $\begin{array}{r}-0.026 \\
(0.00)\end{array}$ & 1 & & & & & & & & & & & & \\
\hline (11)PPI & $\begin{array}{c}-0.019 \\
(0.00)\end{array}$ & $\begin{array}{c}-0.016 \\
(0.00)(0\end{array}$ & $\begin{array}{r}-0.1 \\
0.00)\end{array}$ & $\begin{array}{c}-0.068 \\
(0.00)\end{array}$ & $\begin{array}{c}-0.042 \\
(0.00)\end{array}$ & $\begin{array}{l}-0.086 \\
(0.00)\end{array}$ & $\begin{array}{l}-0.051 \\
(0.00)\end{array}$ & $\begin{array}{c}0.178 \\
(0.00)\end{array}$ & $\begin{array}{c}0.283 \\
(0.00)\end{array}$ & $\left\{\begin{array}{r}-0.1 \\
(0.00)\end{array}\right.$ & 1 & & & & & & & & & & & \\
\hline (12) Share price index & $\begin{array}{r}-0.082 \\
(0.00)\end{array}$ & $\begin{array}{c}-0.013-0 \\
(0.00)(0\end{array}$ & $\begin{array}{l}0.157 \\
0.00)\end{array}$ & $\begin{array}{r}-0.063 \\
(0.00)\end{array}$ & $\begin{array}{l}0.043 \\
(0.00)\end{array}$ & $\begin{array}{l}-0.122 \\
(0.00)\end{array}$ & $\begin{array}{r}-0.018 \\
(0.00)\end{array}$ & $(0.00)$ & $\begin{array}{r}-0.018 \\
(0.00)\end{array}$ & $\begin{array}{l}0.026 \\
(0.00)\end{array}$ & $\begin{array}{c}0.239 \\
(0.00)\end{array}$ & 1 & & & & & & & & & & \\
\hline (13)Quarterly GDP & $\begin{array}{c}-0.056 \\
(0.00)\end{array}$ & $\begin{array}{l}-0.085-0 \\
(0.00)(0\end{array}$ & $\begin{array}{l}0.237 \\
0.00)-\end{array}$ & $\begin{array}{r}-0.005 \\
-(0.14)\end{array}$ & $\begin{array}{c}0.025 \\
(0.00)\end{array}$ & $\begin{array}{l}-0.151 \\
(0.00)\end{array}$ & $\begin{array}{l}-0.447 \\
(0.00)\end{array}$ & $\begin{array}{l}-0.107 \\
(0.00)\end{array}$ & $\begin{array}{l}0.087 \\
(0.00)\end{array}$ & $\begin{array}{l}-0.108 \\
(0.00)\end{array}$ & $\begin{array}{c}0.066 \\
(0.00)\end{array}$ & $\begin{array}{c}0.071 \\
(0.00)\end{array}$ & 1 & & & & & & & & & \\
\hline (14)Excess market return & $\begin{array}{r}-0.001 \\
-(0.65)\end{array}$ & $\begin{array}{l}0.037-0 \\
(0.00)(0\end{array}$ & $\begin{array}{l}0.026 \\
0.00)-\end{array}$ & $\begin{array}{r}-0.003 \\
-(0.37)\end{array}$ & $\begin{array}{l}-0.011 \\
-(0.02)-\end{array}$ & $\begin{array}{r}0.003 \\
-(0.30)\end{array}$ & $\begin{array}{l}-0.045 \\
(0.00)-\end{array}$ & $\begin{array}{l}-0.009- \\
-(0.01)\end{array}$ & $\begin{array}{r}-0.035 \\
(0.00)\end{array}$ & $\begin{array}{r}0.01 \\
(0.00)\end{array}$ & $\begin{array}{l}-0.048 \\
(0.00)-\end{array}$ & $\begin{array}{l}-0.007 \\
-(0.04)\end{array}$ & $\begin{array}{c}0.048 \\
(0.00)\end{array}$ & 1 & & & & & & & & \\
\hline (15) SMB & $\begin{array}{c}-0.004 \\
-(0.26)\end{array}$ & $\begin{array}{c}0.021-0 \\
(0.00)(0\end{array}$ & $\begin{array}{l}0.061 \\
0.00)-\end{array}$ & $\begin{array}{r}0.001 \\
-(0.88)\end{array}$ & $\begin{array}{r}0.006 \\
-(0.23)\end{array}$ & $\begin{array}{l}-0.013 \\
(0.00)\end{array}$ & $\begin{array}{c}-0.077 \\
(0.00)\end{array}$ & $\begin{array}{l}-0.027- \\
(0.00)\end{array}$ & $\begin{array}{l}-0.045 \\
(0.00)-(\end{array}$ & $\begin{array}{r}0.005 \\
-(0.11)\end{array}$ & $\begin{array}{c}-0.04 \\
(0.00)-\end{array}$ & $\begin{array}{r}0.007 \\
-(0.03)\end{array}$ & $\begin{array}{c}0.022 \\
(0.00)\end{array}$ & $\begin{array}{r}-0.5 \\
(0.00)\end{array}$ & 1 & L & & & & & & \\
\hline (16)HML & $\begin{array}{c}-0.024 \\
(0.00)-\end{array}$ & $\begin{array}{l}-0.004 \\
-(0.16)(0\end{array}$ & $\begin{array}{l}-0.05 \\
0.00)\end{array}$ & $\begin{array}{c}-0.031 \\
(0.00)\end{array}$ & $\begin{array}{c}-0.034 \\
(0.00)\end{array}$ & $\begin{array}{l}-0.022 \\
(0.00)\end{array}$ & $\begin{array}{l}-0.057 \\
(0.00)\end{array}$ & $\begin{array}{c}0.021 \\
(0.00)\end{array}$ & $\begin{array}{c}0.036 \\
(0.00)\end{array}$ & $\begin{array}{l}-0.014 \\
(0.00)\end{array}$ & $\begin{array}{r}0 \\
-(0.92)-\end{array}$ & $\begin{array}{r}0.009 \\
-(0.01)\end{array}$ & $\begin{array}{l}0.052 \\
(0.00)\end{array}$ & $\begin{array}{c}0.203 \\
(0.00)\end{array}$ & $\begin{array}{c}-0.036 \\
(0.00)\end{array}$ & 1 & & & & & & \\
\hline (17)Risk-free rate & $\begin{array}{c}-0.165 \\
(0.00)\end{array}$ & $\begin{array}{l}-0.139-0 \\
(0.00)(0\end{array}$ & $\begin{array}{l}0.141 \\
0.00)\end{array}$ & $\begin{array}{r}-0.207 \\
(0.00)\end{array}$ & $\begin{array}{r}-0.3 \\
(0.00)\end{array}$ & $\begin{array}{l}-0.224 \\
(0.00)\end{array}$ & $\begin{array}{c}-0.308 \\
(0.00)\end{array}$ & $\begin{array}{c}0.412 \\
(0.00)\end{array}$ & $\begin{array}{c}0.653 \\
(0.00)\end{array}$ & $\begin{array}{l}-0.078 \\
(0.00)\end{array}$ & $\begin{array}{c}0.288 \\
(0.00)\end{array}$ & $\begin{array}{c}0.116 \\
(0.00)\end{array}$ & $\begin{array}{l}0.264 \\
(0.00)\end{array}$ & $\begin{array}{l}-0.019 \\
(0.00)\end{array}$ & $\begin{array}{c}-0.04 \\
(0.00)\end{array}$ & $\begin{array}{c}0.046 \\
(0.00)\end{array}$ & 1 & & & & & \\
\hline (18)WML & $\begin{array}{c}-0.012 \\
(0.00)\end{array}$ & $\begin{array}{c}-0.03-0 \\
(0.00)(0\end{array}$ & $\begin{array}{l}0.035 \\
0.00)-\end{array}$ & $\begin{array}{r}-0.007 \\
-(0.04)\end{array}$ & $\begin{array}{r}-0.011 \\
-(0.02)\end{array}$ & $\begin{array}{l}-0.021 \\
(0.00)\end{array}$ & $\begin{array}{c}-0.071 \\
(0.00)\end{array}$ & $\begin{array}{c}0.016 \\
(0.00)\end{array}$ & $\begin{array}{c}0.031 \\
(0.00)-\end{array}$ & $\begin{array}{r}0 \\
-(0.97)\end{array}$ & $\begin{array}{r}0.066 \\
(0.00)\end{array}$ & $\begin{array}{c}0.019 \\
(0.00)\end{array}$ & $\begin{array}{l}0.021 \\
(0.00)\end{array}$ & $\begin{array}{l}-0.323 \\
(0.00)\end{array}$ & $\begin{array}{c}0.262 \\
(0.00)\end{array}$ & $\begin{array}{r}-0.303 \\
(0.00)\end{array}$ & $\begin{array}{c}0.044 \\
(0.00)\end{array}$ & 1 & & & & \\
\hline (19)ECB monetary policy assets & $\begin{array}{c}0.112 \\
(0.00)\end{array}$ & $\begin{array}{c}0.1110 \\
(0.00)(C\end{array}$ & $\begin{array}{l}0.014 \\
0.00)\end{array}$ & $\begin{array}{c}0.288 \\
(0.00)\end{array}$ & $\begin{array}{c}0.446 \\
(0.00)\end{array}$ & $\begin{array}{c}0.155 \\
(0.00)-\end{array}$ & $\begin{array}{r}0.002 \\
-(0.48)\end{array}$ & $\begin{array}{l}-0.542 \\
(0.00)\end{array}$ & $\begin{array}{c}-0.6 \\
(0.00)-(\end{array}$ & $\begin{array}{r}0.007 \\
-(0.05) \\
-(0.05\end{array}$ & $\begin{array}{r}0.001 \\
-(0.72)\end{array}$ & $\begin{array}{c}0.071 \\
(0.00)\end{array}$ & $\begin{array}{l}-0.08 \\
(0.00)\end{array}$ & $\begin{array}{l}-0.011 \\
(0.00)-\end{array}$ & $\begin{array}{r}0.003 \\
-(0.41)\end{array}$ & $\begin{array}{l}-0.051- \\
(0.00)\end{array}$ & $\begin{array}{l}-0.456 \\
(0.00)\end{array}$ & $\begin{array}{c}-0.018 \\
(0.00)\end{array}$ & 1 & & & \\
\hline (20)MtB & $\begin{array}{r}-0.018 \\
(0.00)\end{array}$ & $\begin{array}{c}-0.043-0 \\
(0.00)(0\end{array}$ & $0.016-$ & $\begin{array}{r}-0.001 \\
-(0.65)\end{array}$ & $\begin{array}{c}-0.024 \\
(0.00)\end{array}$ & $\begin{array}{l}-0.033 \\
(0.00)-\end{array}$ & $\begin{array}{r}-0.002 \\
-(0.58)\end{array}$ & $\begin{array}{c}0.013 \\
(0.00)\end{array}$ & $\begin{array}{c}0.012 \\
(0.00)-\end{array}$ & $\begin{array}{r}0 \\
-(0.88)-\end{array}$ & $\begin{array}{l}-0.007 \\
-(0.05)\end{array}$ & $\begin{array}{r}0.01- \\
(0.00)\end{array}$ & $\begin{array}{l}-0.009 \\
(0.00)-\end{array}$ & $\begin{array}{l}-0.003 \\
-(0.36)-\end{array}$ & $\begin{array}{r}0.003 \\
-(0.41)\end{array}$ & $\begin{array}{c}0.013 \\
(0.00)\end{array}$ & $\begin{array}{c}0.01 \\
(0.00)-\end{array}$ & $\begin{array}{r}0.003- \\
-(0.43)\end{array}$ & $\begin{array}{l}-0.027 \\
(0.00)\end{array}$ & 1 & & \\
\hline (21)Misvaluation & $\begin{array}{c}0.058 \\
(0.00)\end{array}$ & $\begin{array}{c}0.0930 \\
(0.00)(0\end{array}$ & 0.011 & $\begin{array}{r}-0.299 \\
(0.00)\end{array}$ & $\begin{array}{c}-0.12 \\
(0.00)\end{array}$ & $\begin{array}{c}-0.22 \\
(0.00)\end{array}$ & $\begin{array}{r}-0.067 \\
(0.00)\end{array}$ & $\begin{array}{c}0.112 \\
(0.00)\end{array}$ & $\begin{array}{c}0.189 \\
(0.00)\end{array}$ & $\begin{array}{l}-0.108 \\
(0.00)\end{array}$ & $\begin{array}{r}0.06 \\
(0.00)\end{array}$ & $\begin{array}{c}0.131 \\
(0.00)\end{array}$ & $\begin{array}{l}0.111 \\
(0.00)\end{array}$ & $\begin{array}{l}0.018 \\
(0.00)-\end{array}$ & $\begin{array}{r}0.005 \\
-(0.14)\end{array}$ & $\begin{array}{c}0.044 \\
(0.00)\end{array}$ & $\begin{array}{l}0.257 \\
(0.00)-\end{array}$ & $\begin{array}{r}0.006- \\
-(0.04)\end{array}$ & $\begin{array}{l}0.271 \\
(0.00)\end{array}$ & $\begin{array}{r}0.324 \\
(0.00)\end{array}$ & 1 & \\
\hline (22)MV & $\begin{array}{r}0.48 \\
(0.00)\end{array}$ & $\begin{array}{c}0.2050 \\
(0.00)(0\end{array}$ & $\begin{array}{l}0.135 \\
0.00)\end{array}$ & $\begin{array}{r}-0.047 \\
(0.00)\end{array}$ & $\begin{array}{r}-0.03 \\
(0.00)\end{array}$ & $\begin{array}{l}-0.103 \\
(0.00)\end{array}$ & $\begin{array}{c}-0.01 \\
(0.00)\end{array}$ & $\begin{array}{l}-0.093 \\
(0.00)\end{array}$ & $\begin{array}{c}-0.03 \\
(0.00)\end{array}$ & $\begin{array}{l}-0.116 \\
(0.00)\end{array}$ & $\begin{array}{c}0.039 \\
(0.00)\end{array}$ & $\begin{array}{r}-0.002 \\
-(0.48)\end{array}$ & $\begin{array}{l}0.067 \\
(0.00)-\end{array}$ & $\begin{array}{r}0.003 \\
-(0.27)-\end{array}$ & $\begin{array}{r}0.005 \\
-(0.10)\end{array}$ & $\begin{array}{r}0.003 \\
-(0.34)\end{array}$ & $\begin{array}{c}0.024 \\
(0.00)-\end{array}$ & $\begin{array}{r}0.006 \\
-(0.04)\end{array}$ & $\begin{array}{l}0.017- \\
(0.00)\end{array}$ & $\begin{array}{c}-0.015 \\
(0.00)(\end{array}$ & $\begin{array}{r}0.137 \\
(0.00)\end{array}$ & 1 \\
\hline
\end{tabular}

\begin{tabular}{|c|c|c|c|c|c|c|c|c|c|c|c|c|c|c|c|c|c|c|c|c|c|}
\hline & (1) & $(2)$ & (4) & $(5)$ & (6) & (7) & (8) & (9) & (10) & (11) & (12) & $(13)$ & (14) & (15) & $(16)$ & (17) & (18) & (19) & (20) & $(21)(2$ & \\
\hline (1)SRISK & 1 & & & & & & & & & & & & & & & & & & & & \\
\hline (2)Beta & $\begin{array}{r}0.395 \\
(0.00)\end{array}$ & 1 & & & & & & & & & & & & & & & & & & & \\
\hline (3)Delta CoVaR & $\begin{array}{r}0.376 \\
(0.00)\end{array}$ & $\begin{array}{rl}0.581 & 1 \\
(0.00) & \end{array}$ & & & & & & & & & & & & & & & & & & & \\
\hline (4)Z-score & $\begin{array}{r}-0.035 \\
(0.00)\end{array}$ & $\begin{array}{r}-0.189-0.028 \\
(0.00)(0.00)\end{array}$ & 1 & L & & & & & & & & & & & & & & & & & \\
\hline (5)CAPR3 & $\begin{array}{r}0.022 \\
(0.00)\end{array}$ & $\begin{array}{r}-0.097-0.128 \\
(0.00)(0.00)\end{array}$ & $\begin{array}{r}0.18 \\
(0.00)\end{array}$ & 1 & & & & & & & & & & & & & & & & & \\
\hline (6) LVG & $\begin{array}{r}0.211 \\
(0.00)\end{array}$ & $\begin{array}{r}0.0320 .108 \\
(0.00)(0.00)\end{array}$ & $\begin{array}{r}0.189 \\
(0.00)\end{array}$ & $\begin{array}{r}0.066 \\
(0.00)\end{array}$ & 1 & 1 & & & & & & & & & & & & & & & \\
\hline (7) CISS & $\begin{array}{r}0.153 \\
(0.00)\end{array}$ & 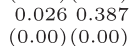 & $\begin{array}{c}0.062 \\
(0.00)\end{array}$ & $\begin{array}{l}-0.103 \\
(0.00)\end{array}$ & $\begin{array}{r}0.17 \\
(0.00)\end{array}$ & 1 & & & & & & & & & & & & & & & \\
\hline (8)LT interest rates & $\begin{array}{c}-0.154 \\
(0.00)\end{array}$ & $\begin{array}{r}0.0910 .057 \\
(0.00)(0.00)\end{array}$ & $\begin{array}{l}-0.34 \\
(0.00)\end{array}$ & $\begin{array}{l}-0.504 \\
(0.00)\end{array}$ & $\begin{array}{l}-0.05 \\
(0.00)\end{array}$ & $\begin{array}{l}-0.016 \\
(0.00)\end{array}$ & 1 & 1 & & & & & & & & & & & & & \\
\hline (9) ST interest rates & $\begin{array}{r}-0.142 \\
(0.00)\end{array}$ & $\begin{array}{r}-0.085-0.021 \\
(0.00)(0.00)\end{array}$ & $\begin{array}{l}-0.261 \\
(0.00)\end{array}$ & $\begin{array}{l}-0.39 \\
(0.00)\end{array}$ & $\begin{array}{l}-0.157 \\
(0.00)\end{array}$ & $\begin{array}{l}-0.093 \\
(0.00)\end{array}$ & $\begin{array}{r}0.716 \\
(0.00)\end{array}$ & ) & 1 & & & & & & & & & & & & \\
\hline (10)HUR & $\begin{array}{r}-0.06 \\
(0.00)\end{array}$ & $\begin{array}{r}0.2630 .131 \\
(0.00)(0.00)\end{array}$ & -0.091 & $\begin{array}{l}-0.241 \\
(0.00)\end{array}$ & $\begin{array}{r}0.056 \\
(0.00)\end{array}$ & $\begin{array}{r}-0.08 \\
(0.00)\end{array}$ & $\begin{array}{l}0.37-0 \\
0.00)(8\end{array}$ & $\begin{array}{l}-0.026 \\
(0.00)\end{array}$ & 6 & & & & & & & & & & & & \\
\hline (11)PPI & $\begin{array}{l}-0.019 \\
(0.00)\end{array}$ & $\begin{array}{cc}-0.016 & -0.1 \\
(0.00) & (0.00)\end{array}$ & $\begin{array}{l}-0.068 \\
(0.00)\end{array}$ & $\begin{array}{l}-0.042 \\
(0.00)\end{array}$ & $\begin{array}{l}-0.086 \\
(0.00)\end{array}$ & $\begin{array}{l}-0.051 \\
0.00)\end{array}$ & $\begin{array}{l}0.178 \\
(0.00)(8\end{array}$ & $\begin{array}{l}0.283 \\
(0.00)\end{array}$ & $\begin{array}{l}3 \\
\\
(0.00)\end{array}$ & 1 & & & & & & & & & & & \\
\hline (12) Share price index & $\begin{array}{r}-0.082 \\
(0.00)\end{array}$ & $\begin{array}{r}-0.013-0.157 \\
(0.00)(0.00)\end{array}$ & $\begin{array}{l}-0.063 \\
(0.00)\end{array}$ & $\begin{array}{c}0.043 \\
(0.00)\end{array}$ & $\begin{array}{l}-0.122 \\
(0.00)\end{array}$ & $\begin{array}{l}-0.018 \\
0.00)\end{array}$ & $\begin{array}{l}-0.062-0 \\
0.00)(8\end{array}$ & $\begin{array}{l}-0.018 \\
(0.00)\end{array}$ & $\begin{array}{r}0.026 \\
(0.00)\end{array}$ & $\begin{array}{r}0.239 \\
(0.00)\end{array}$ & 1 & & & & & & & & & & \\
\hline (13)Quarterly GDP & $\begin{array}{l}-0.056 \\
(0.00)\end{array}$ & $\begin{array}{c}-0.085-0.237 \\
(0.00)(0.00)-\end{array}$ & $\begin{array}{r}-0.005 \\
-(0.14)\end{array}$ & $\begin{array}{c}0.025 \\
(0.00)\end{array}$ & $\begin{array}{l}-0.151 \\
(0.00)\end{array}$ & -0.447 & $\begin{array}{l}-0.107 \\
(0.00)(8\end{array}$ & $\begin{array}{l}0.087 \\
(0.00)\end{array}$ & $(0.00)$ & $\begin{array}{r}0.066 \\
(0.00)\end{array}$ & $\begin{array}{r}0.071 \\
(0.00)\end{array}$ & 1 & & & & & & & & & \\
\hline (14)Excess market return & $\begin{array}{r}-0.001 \\
-(0.65)\end{array}$ & $\begin{array}{c}0.037-0.026 \\
(0.00)(0.00)\end{array}$ & $\begin{array}{l}-0.003 \\
-(0.37)-\end{array}$ & $\begin{array}{l}-0.011 \\
-(0.02)-\end{array}$ & $\begin{array}{r}0.003 \\
-(0.30)\end{array}$ & $\begin{array}{l}-0.045 \\
(0.00)-\end{array}$ & $\begin{array}{r}-0.009-0 \\
-(0.01)(8\end{array}$ & $\begin{array}{l}-0.035 \\
(0.00)\end{array}$ & $\begin{array}{r}0.01- \\
(0.00)\end{array}$ & $\begin{array}{l}-0.048 \\
(0.00)-\end{array}$ & $\begin{array}{l}-0.007 \\
-(0.04)(\end{array}$ & $\begin{array}{l}0.048 \\
(0.00)\end{array}$ & 1 & & & & & & & & \\
\hline (15)SMB & $\begin{array}{l}-0.004 \\
-(0.26)\end{array}$ & $\begin{array}{c}0.021-0.061 \\
(0.00)(0.00)\end{array}$ & $\begin{array}{c}0.001 \\
-(0.88)-\end{array}$ & $\begin{array}{r}0.006 \\
-(0.23)\end{array}$ & $\begin{array}{l}-0.013 \\
(0.00)\end{array}$ & $\begin{array}{l}-0.077 \\
(0.00)\end{array}$ & $\begin{array}{l}-0.027-0 \\
(0.00)(\end{array}$ & $\begin{array}{l}-0.045 \\
(0.00)-\end{array}$ & $\begin{array}{r}0.005 \\
-(0.11)\end{array}$ & $\begin{array}{c}-0.04 \\
(0.00)-\end{array}$ & $\begin{array}{r}0.007 \\
-(0.03)(\end{array}$ & $\begin{array}{l}0.022 \\
(0.00)\end{array}$ & $\begin{array}{r}-0.5 \\
(0.00)\end{array}$ & 1 & & & & & & & \\
\hline (16)HML & $\begin{array}{l}-0.024 \\
(0.00)-\end{array}$ & $\begin{array}{r}-0.004-0.05 \\
-(0.16)(0.00)\end{array}$ & -0.031 & -0.034 & $\begin{array}{l}-0.022 \\
(0.00)\end{array}$ & -0.057 & 0.0210 & $\begin{array}{l}0.036 \\
(0.00)\end{array}$ & $(0.00)-($ & $\begin{array}{r}0 \\
-(0.92)-\end{array}$ & $\begin{array}{r}0.009 \\
-(0.01)(\end{array}$ & $\begin{array}{l}0.052 \\
(0.00)\end{array}$ & $(0.00)$ & $\begin{array}{l}-0.036 \\
(0.00)\end{array}$ & 1 & & & & & & \\
\hline (17)Risk-free rate & $\begin{array}{r}-0.165 \\
(0.00)\end{array}$ & $\begin{array}{r}-0.139-0.141 \\
(0.00)(0.00)\end{array}$ & -0.207 & $(0.00)$ & $\begin{array}{l}-0.224 \\
(0.00)\end{array}$ & $\begin{array}{l}-0.308 \\
(0.00)\end{array}$ & $\begin{array}{l}0.4120 \\
(0.00)(0\end{array}$ & $\begin{array}{l}0.653 \\
(0.00)\end{array}$ & $(0.00)$ & $\begin{array}{r}0.288 \\
(0.00)\end{array}$ & $\begin{array}{r}0.116 \\
(0.00)(\end{array}$ & $\begin{array}{l}0.264 \\
(0.00)\end{array}$ & $\begin{array}{l}-0.019 \\
(0.00)\end{array}$ & $(0.00)$ & $\begin{array}{l}0.046 \\
(0.00)\end{array}$ & 1 & & & & & \\
\hline (18)WML & $\begin{array}{r}-0.012 \\
(0.00)\end{array}$ & $\begin{array}{r}-0.03-0.035 \\
(0.00)(0.00)\end{array}$ & -0.007 & -0.011 & $\begin{array}{l}-0.021 \\
(0.00)\end{array}$ & $\begin{array}{l}-0.071 \\
(0.00)\end{array}$ & $\begin{array}{l}0.0160 \\
(0.00)(0\end{array}$ & $\begin{array}{l}0.031 \\
(0.00)\end{array}$ & $\begin{array}{r}0 \\
1 \\
-(0.97)\end{array}$ & $\begin{array}{l}0.066 \\
(0.00)\end{array}$ & $\begin{array}{l}0.019 \\
(0.00)(\end{array}$ & $\begin{array}{l}0.021 \\
(0.00)\end{array}$ & -0.323 & $0.262-$ & -0.3030 & $\begin{array}{c}0.044 \\
(0.00)\end{array}$ & 1 & & & & \\
\hline (19) ECB monetary policy assets & $\begin{array}{r}0.112 \\
(0.00)\end{array}$ & $\begin{array}{r}0.1110 .014 \\
(0.00)(0.00)\end{array}$ & $\begin{array}{l}0.288 \\
(0.00)\end{array}$ & $\begin{array}{r}0.446 \\
(0.00)\end{array}$ & $\begin{array}{l}0.155 \\
(0.00)-\end{array}$ & $\begin{array}{r}0.002 \\
-(0.48)\end{array}$ & $\begin{array}{l}-0.542 \\
(0.00)(0\end{array}$ & $\begin{array}{l}-0.6 \\
(0.00)-\end{array}$ & $\begin{array}{l}60.007 \\
)-(0.05)-(\end{array}$ & $\begin{array}{r}0.001 \\
-(0.72)\end{array}$ & $\begin{array}{l}0.071 \\
(0.00)(\end{array}$ & $\begin{array}{l}-0.08 \\
(0.00)\end{array}$ & $\begin{array}{l}-0.011 \\
(0.00)-\end{array}$ & $\begin{array}{r}0.003 \\
-(0.41)\end{array}$ & $\begin{array}{l}-0.051-0 \\
(0.00)(\end{array}$ & $\begin{array}{l}-0.456 \\
(0.00)\end{array}$ & $\begin{array}{l}-0.018 \\
(0.00)\end{array}$ & 1 & & & \\
\hline (20)MtB & $\begin{array}{r}-0.018 \\
(0.00)\end{array}$ & $\begin{array}{c}-0.043-0.016 \\
(0.00)(0.00)-\end{array}$ & $\begin{array}{l}-0.001 \\
-(0.65)\end{array}$ & $\begin{array}{l}-0.024 \\
(0.00)\end{array}$ & $\begin{array}{l}-0.033 \\
(0.00)-\end{array}$ & $\begin{array}{l}-0.002 \\
-(0.58)\end{array}$ & $\begin{array}{r}0.0130 \\
(0.00)(0\end{array}$ & $\begin{array}{l}0.012 \\
(0.00)-\end{array}$ & $\begin{array}{r}0- \\
-(0.88)-(\end{array}$ & $\begin{array}{l}-0.007 \\
-(0.05)\end{array}$ & $\begin{array}{r}0.01- \\
(0.00)(\end{array}$ & $\begin{array}{l}-0.009 \\
(0.00)-\end{array}$ & $\begin{array}{l}-0.003 \\
-(0.36)-\end{array}$ & $\begin{array}{r}0.003 \\
-(0.41)\end{array}$ & $\begin{array}{l}0.013 \\
(0.00)\end{array}$ & $\begin{array}{r}0.01 \\
(0.00)\end{array}$ & $\begin{array}{r}0.003-1 \\
-(0.43)(\end{array}$ & $\begin{array}{l}-0.027 \\
(0.00)\end{array}$ & 1 & & \\
\hline (21) Misvaluation & $\begin{array}{r}0.058 \\
(0.00)\end{array}$ & $\begin{array}{r}0.0930 .011 \\
(0.00)(0.00)\end{array}$ & $\begin{array}{l}-0.299 \\
(0.00)\end{array}$ & $\begin{array}{r}-0.12 \\
(0.00)\end{array}$ & $\begin{array}{l}-0.22 \\
(0.00)\end{array}$ & $\begin{array}{l}-0.067 \\
(0.00)\end{array}$ & $\begin{array}{l}0.1120 \\
(0.00)(0\end{array}$ & $\begin{array}{l}0.189 \\
(0.00)\end{array}$ & $\begin{array}{l}-0.108 \\
(0.00)\end{array}$ & $\begin{array}{r}0.06 \\
(0.00)\end{array}$ & $\begin{array}{l}0.131 \\
(0.00)(\end{array}$ & $\begin{array}{l}0.111 \\
(0.00)\end{array}$ & $\begin{array}{l}0.018 \\
(0.00)-\end{array}$ & $\begin{array}{r}0.005 \\
-(0.14)\end{array}$ & $\begin{array}{l}0.0440 \\
(0.00)(\end{array}$ & $\begin{array}{l}0.257 \\
(0.00)\end{array}$ & $\begin{array}{r}0.006-C \\
-(0.04)(\end{array}$ & $\begin{array}{l}-0.271 \\
(0.00)(\end{array}$ & $\begin{array}{l}0.324 \\
(0.00)\end{array}$ & 1 & \\
\hline (22) MV & $\begin{array}{r}0.48 \\
(0.00)\end{array}$ & 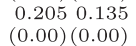 & $\begin{array}{l}-0.047 \\
(0.00)\end{array}$ & $\begin{array}{l}-0.03 \\
(0.00)\end{array}$ & $\begin{array}{l}-0.103 \\
(0.00)\end{array}$ & $\left\{\begin{array}{r}-0.01 \\
(0.00)\end{array}\right.$ & $\begin{array}{l}-0.093 \\
(0.00)(0\end{array}$ & $\begin{array}{l}-0.03 \\
(0.00)\end{array}$ & $\begin{array}{l}-0.116 \\
(0.00)\end{array}$ & $\begin{array}{l}0.039 \\
(0.00)-\end{array}$ & $\begin{array}{l}-0.002 \\
-(0.48)(\end{array}$ & $\begin{array}{l}0.067 \\
(0.00)-\end{array}$ & $\begin{array}{r}0.003 \\
-(0.27)-\end{array}$ & $\begin{array}{c}0.005 \\
-(0.10)-\end{array}$ & $\begin{array}{r}0.003 \\
-(0.34)( \\
\end{array}$ & $\begin{array}{c}0.024 \\
(0.00)\end{array}$ & $\begin{array}{r}0.006 \\
-(0.04)(\end{array}$ & $\begin{array}{l}0.017- \\
(0.00)(\end{array}$ & $\begin{array}{l}-0.0150 \\
(0.00)(\end{array}$ & $\begin{array}{l}0.137 \\
(0.00)\end{array}$ & 1 \\
\hline
\end{tabular}

a This table reports the correlation matrix between the main variables used in the empirical analysis.

${ }^{a_{\text {This }}}$ table reports the correlation matrix between the main variables used in the empirical analysis. 
Table 6

Variable Summary Statistics by sub-periods.

\begin{tabular}{|c|c|c|c|c|c|c|c|}
\hline & & Mean & SE mean & p25 & p50 & p75 & $\mathrm{N}$ \\
\hline \multirow[t]{10}{*}{ Total } & SRISK & 12902.19 & 99.9799 & -20.28 & 1065.18 & 8999.35 & 101,711 \\
\hline & Beta & 0.8483 & 0.0017 & 0.4394 & 0.7923 & 1.1691 & 101,711 \\
\hline & Delta CoVaR & 0.0087 & 0.0000 & 0.0053 & 0.0076 & 0.0107 & 101,711 \\
\hline & Z-score & 38.0801 & 0.1531 & 10.0034 & 21.1330 & 46.1940 & 100,820 \\
\hline & CAPR & 14.5839 & 0.0231 & 11.4000 & 13.6000 & 16.6000 & 47,460 \\
\hline & LVG & 27.4973 & 0.1073 & 8.4039 & 16.5865 & 31.3520 & 101,711 \\
\hline & $\mathrm{MtB}$ & 5.9147 & 0.3913 & 0.6369 & 1.1024 & 1.8770 & 101,456 \\
\hline & Misvaluation & 0.2320 & 0.0021 & -0.1114 & 0.2525 & 0.5971 & 100,770 \\
\hline & MV & 12560.86 & 77.5563 & 474.16 & 2338.72 & 11199.49 & 101,711 \\
\hline & MV (centered) & 0.0000 & 0.0031 & -0.7714 & -0.1643 & 0.6207 & 101,711 \\
\hline \multirow[t]{10}{*}{ Basel I } & SRISK & 4396.97 & 49.9067 & 659.35 & 2437.70 & 7245.93 & 9684 \\
\hline & Beta & 0.8714 & 0.0037 & 0.6072 & 0.8609 & 1.1132 & 9684 \\
\hline & Delta CoVaR & 0.0082 & 0.0000 & 0.0063 & 0.0080 & 0.0098 & 9684 \\
\hline & Z-score & 15.6732 & 0.0906 & 8.4170 & 16.0849 & 21.9981 & 9197 \\
\hline & CAPR7 & 10.9386 & 0.0351 & 9.8000 & 10.7000 & 12.2000 & 1987 \\
\hline & LVG & 21.9066 & 0.1460 & 13.4111 & 18.9761 & 28.1987 & 9684 \\
\hline & $\mathrm{MtB}$ & 1.2977 & 0.0084 & 0.8844 & 1.1010 & 1.4708 & 9684 \\
\hline & Misvaluation & 0.2362 & 0.0039 & 0.0632 & 0.2178 & 0.4157 & 9197 \\
\hline & MV & 4915.17 & 54.0277 & 1217.19 & 2784.40 & 6816.23 & 9684 \\
\hline & MV (centered) & -1.0523 & 0.0038 & -1.2815 & -1.0434 & -0.9196 & 9684 \\
\hline \multirow[t]{10}{*}{ Market Risk Amendment } & SRISK & 5378.94 & 77.8927 & -195.74 & 287.26 & 5456.72 & 34,464 \\
\hline & Beta & 0.7180 & 0.0025 & 0.3503 & 0.6789 & 1.0361 & 34,464 \\
\hline & Delta CoVaR & 0.0077 & 0.0000 & 0.0049 & 0.0068 & 0.0095 & 34,464 \\
\hline & Z-score & 21.5541 & 0.1430 & 7.4325 & 13.9033 & 25.8403 & 34,333 \\
\hline & CAPR & 12.3825 & 0.0246 & 10.7000 & 11.7000 & 13.3000 & 16,037 \\
\hline & LVG & 17.9126 & 0.1134 & 6.2289 & 11.3362 & 21.2066 & 34,464 \\
\hline & $\mathrm{MtB}$ & 15.1617 & 1.1504 & 1.0855 & 1.7167 & 2.5813 & 34,464 \\
\hline & Misvaluation & 0.4928 & 0.0038 & 0.2321 & 0.5104 & 0.7855 & 34,320 \\
\hline & MV & 12558.90 & 122.1151 & 477.70 & 2437.02 & 13514.81 & 34,464 \\
\hline & MV (centered) & -0.1741 & 0.0045 & -0.7755 & -0.3178 & 0.3321 & 34,464 \\
\hline \multirow[t]{10}{*}{ Basel II } & SRISK & 15650.81 & 390.1472 & -349.28 & 389.28 & 8242.02 & 9920 \\
\hline & Beta & 0.8108 & 0.0043 & 0.4651 & 0.8131 & 1.0961 & 9920 \\
\hline & Delta CoVaR & 0.0078 & 0.0000 & 0.0050 & 0.0070 & 0.0098 & 9920 \\
\hline & Z-score & 43.9747 & 0.5137 & 12.5799 & 25.9318 & 56.2483 & 9920 \\
\hline & CAPR9 & 12.1698 & 0.0444 & 10.7000 & 11.7000 & 13.5000 & 2790 \\
\hline & LVG & 19.6551 & 0.2653 & 6.0843 & 10.7152 & 21.2849 & 9920 \\
\hline & $\mathrm{MtB}$ & 1.9472 & 0.0152 & 1.1768 & 1.7363 & 2.4540 & 9920 \\
\hline & Misvaluation & 0.3920 & 0.0062 & 0.1518 & 0.4749 & 0.7454 & 9920 \\
\hline & MV & 21713.28 & 359.6619 & 751.56 & 4766.06 & 24493.16 & 9920 \\
\hline & MV (centered) & 1.3718 & 0.0104 & 0.6683 & 1.4569 & 2.1294 & 9920 \\
\hline \multirow[t]{10}{*}{ Basel III } & SRISK & 24073.99 & 525.6244 & 89.34 & 1590.32 & 14405.69 & 9003 \\
\hline & Beta & 0.8967 & 0.0059 & 0.4496 & 0.8007 & 1.2751 & 9003 \\
\hline & Delta CoVaR & 0.0132 & 0.0001 & 0.0069 & 0.0104 & 0.0160 & 9003 \\
\hline & Z-score & 45.1617 & 0.5437 & 12.8385 & 27.4082 & 55.9498 & 8977 \\
\hline & CAPR & 12.1652 & 0.0951 & 10.1100 & 11.4000 & 12.7800 & 988 \\
\hline & LVG & 38.8052 & 0.4919 & 10.7743 & 20.1679 & 45.6950 & 9003 \\
\hline & $\mathrm{MtB}$ & 1.0124 & 0.0082 & 0.5451 & 0.8481 & 1.2830 & 8978 \\
\hline & Misvaluation & 0.1375 & 0.0065 & -0.2504 & 0.0634 & 0.4523 & 8927 \\
\hline & MV & 11684.27 & 250.1816 & 409.12 & 2278.95 & 9613.10 & 9003 \\
\hline & MV (centered) & 0.0029 & 0.0086 & -0.5258 & 0.0053 & 0.5246 & 9003 \\
\hline \multirow[t]{10}{*}{ European Crisis } & SRISK & 21634.75 & 309.4244 & 144.31 & 2316.05 & 16752.01 & 19,074 \\
\hline & Beta & 1.0090 & 0.0045 & 0.5148 & 0.9143 & 1.3955 & 19,074 \\
\hline & Delta CoVaR & 0.0096 & 0.0000 & 0.0056 & 0.0086 & 0.0122 & 19,074 \\
\hline & Z-score & 49.1784 & 0.3871 & 14.3961 & 32.9161 & 61.2108 & 18,827 \\
\hline & CAPR & 15.0440 & 0.0574 & 12.2500 & 14.4000 & 16.9900 & 9888 \\
\hline & LVG & 40.4968 & 0.3234 & 11.9368 & 24.7335 & 48.8942 & 19,074 \\
\hline & $\mathrm{MtB}$ & 0.9250 & 0.0066 & 0.4156 & 0.7070 & 1.1213 & 18,844 \\
\hline & Misvaluation & 0.0439 & 0.0043 & -0.2784 & 0.0407 & 0.3676 & 18,840 \\
\hline & MV & 12318.13 & 188.7992 & 333.25 & 1629.59 & 9265.94 & 19,074 \\
\hline & MV (centered) & -0.0210 & 0.0058 & -0.6101 & -0.1255 & 0.5243 & 19,074 \\
\hline \multirow[t]{10}{*}{ Banking Union } & SRISK & 15316.34 & 218.9442 & 94.41 & 1612.80 & 12384.42 & 19,566 \\
\hline & Beta & 0.9064 & 0.0042 & 0.4429 & 0.8593 & 1.2411 & 19,566 \\
\hline & Delta CoVaR & 0.0082 & 0.0000 & 0.0052 & 0.0074 & 0.0103 & 19,566 \\
\hline & Z-score & 60.6941 & 0.4670 & 15.5905 & 37.2711 & 72.4498 & 19,566 \\
\hline & CAPR & 17.5718 & 0.0415 & 14.4000 & 16.6000 & 19.3300 & 15,770 \\
\hline & LVG & 33.2472 & 0.2714 & 11.6652 & 20.3025 & 38.6810 & 19,566 \\
\hline & $\mathrm{MtB}$ & 0.9783 & 0.0080 & 0.3928 & 0.7027 & 1.0748 & 19,566 \\
\hline & Misvaluation & -0.0842 & 0.0046 & -0.3610 & -0.0526 & 0.2459 & 19,566 \\
\hline & MV & 12348.17 & 177.5327 & 320.46 & 2042.30 & 9896.64 & 19,566 \\
\hline & MV (centered) & 0.1512 & 0.0065 & -0.5498 & 0.0637 & 0.7742 & 19,566 \\
\hline
\end{tabular}

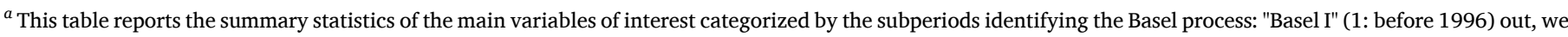

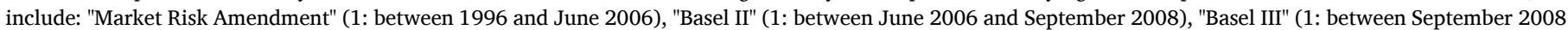
and September 2010), "European Crisis" (1: between September 2010 to November 2014), and "Banking Union" (1: after November 2014). 
Table 7

Variable summary statistics by IRBA categories.

\begin{tabular}{|c|c|c|c|c|c|c|c|}
\hline & & Mean & SE mean & $\mathrm{p} 25$ & p50 & p75 & $\mathrm{N}$ \\
\hline \multirow[t]{10}{*}{ Total } & SRISK & 21270.70 & 204.6984 & 137.78 & 2496.10 & 18709.70 & 41,952 \\
\hline & Beta & 0.9698 & 0.0030 & 0.4812 & 0.9245 & 1.3347 & 41,952 \\
\hline & Delta CoVaR & 0.0095 & 0.0000 & 0.0054 & 0.0082 & 0.0119 & 41,952 \\
\hline & Z-score & 50.0155 & 0.2595 & 15.0274 & 33.0451 & 62.9322 & 41,679 \\
\hline & CAPR & 16.1584 & 0.0367 & 13.0000 & 15.2700 & 17.9000 & 23,890 \\
\hline & LVG & 35.6705 & 0.1971 & 11.8296 & 21.8301 & 41.4966 & 41,952 \\
\hline & $\mathrm{MtB}$ & 1.0087 & 0.0046 & 0.4639 & 0.7727 & 1.2141 & 41,697 \\
\hline & Misvaluation & 0.0747 & 0.0029 & -0.2309 & 0.0557 & 0.3792 & 41,646 \\
\hline & MV & 13262.20 & 124.9815 & 415.25 & 2500.49 & 13122.06 & 41,952 \\
\hline & MV (centered) & 0.1831 & 0.0044 & -0.5041 & 0.0993 & 0.7771 & 41,952 \\
\hline \multirow[t]{10}{*}{ Advanced IRB } & SRISK & 5696.07 & 488.9463 & 207.96 & 504.96 & 879.08 & 1311 \\
\hline & Beta & 0.5792 & 0.0100 & 0.3130 & 0.5321 & 0.7555 & 1311 \\
\hline & Delta CoVaR & 0.0071 & 0.0001 & 0.0046 & 0.0060 & 0.0078 & 1311 \\
\hline & Z-score & 55.0997 & 0.7845 & 37.4176 & 52.3333 & 69.4258 & 1311 \\
\hline & CAPR & 31.7361 & 0.5628 & 13.9000 & 38.8000 & 42.1000 & 570 \\
\hline & LVG & 21.4334 & 0.5732 & 11.4080 & 14.2386 & 27.4385 & 1311 \\
\hline & MtB & 1.6084 & 0.0179 & 0.8616 & 1.8081 & 2.1077 & 1311 \\
\hline & Misvaluation & 0.4692 & 0.0077 & 0.3009 & 0.4895 & 0.6489 & 1311 \\
\hline & MV & 4115.84 & 300.8268 & 737.83 & 1419.82 & 1650.01 & 1311 \\
\hline & MV (centered) & -0.1507 & 0.0237 & -0.9420 & -0.0605 & 0.4631 & 1311 \\
\hline \multirow[t]{10}{*}{ Foundation IRB } & SRISK & 1292.76 & 78.8712 & 205.21 & 534.17 & 945.86 & 2699 \\
\hline & Beta & 0.4150 & 0.0049 & 0.2416 & 0.3673 & 0.5247 & 2699 \\
\hline & Delta CoVaR & 0.0058 & 0.0001 & 0.0038 & 0.0055 & 0.0071 & 2699 \\
\hline & Z-score & 131.2014 & 1.5101 & 59.4071 & 106.0833 & 200.1949 & 2699 \\
\hline & CAPR & 18.2967 & 0.1431 & 14.5000 & 16.9900 & 19.8800 & 1470 \\
\hline & LVG & 55.9720 & 0.8436 & 19.1654 & 43.4757 & 96.2656 & 2699 \\
\hline & $\mathrm{MtB}$ & 0.5958 & 0.0135 & 0.1007 & 0.1583 & 0.7861 & 2699 \\
\hline & Misvaluation & -0.4425 & 0.0126 & -1.1192 & -0.3802 & 0.0362 & 2699 \\
\hline & MV & 2337.68 & 143.2382 & 130.72 & 212.78 & 626.16 & 2699 \\
\hline & MV (centered) & 0.1370 & 0.0153 & -0.4239 & 0.1246 & 0.6049 & 2699 \\
\hline \multirow[t]{10}{*}{ Mixed } & SRISK & 41410.02 & 365.5722 & 4239.35 & 18043.84 & 55093.01 & 20,376 \\
\hline & Beta & 1.2530 & 0.0040 & 0.9053 & 1.2209 & 1.5564 & 20,376 \\
\hline & Delta CoVaR & 0.0120 & 0.0001 & 0.0078 & 0.0104 & 0.0145 & 20,376 \\
\hline & Z-score & 43.4396 & 0.2284 & 19.2012 & 36.5626 & 60.5398 & 20,194 \\
\hline & CAPR & 16.0789 & 0.0389 & 13.5800 & 15.6000 & 18.0000 & 14,156 \\
\hline & LVG & 39.5242 & 0.2722 & 16.9964 & 25.5449 & 44.5354 & 20,376 \\
\hline & $\mathrm{MtB}$ & 0.7375 & 0.0029 & 0.4455 & 0.6810 & 0.9703 & 20,210 \\
\hline & Misvaluation & 0.0534 & 0.0031 & -0.1894 & 0.0466 & 0.2769 & 20,210 \\
\hline & MV & 24679.08 & 227.0739 & 2902.64 & 11708.36 & 38700.31 & 20,376 \\
\hline & MV (centered) & 0.2570 & 0.0059 & -0.3759 & 0.2433 & 0.8409 & 20,376 \\
\hline \multirow[t]{10}{*}{ Standardized } & SRISK & 2141.70 & 74.5968 & -58.63 & 79.20 & 2132.26 & 17,566 \\
\hline & Beta & 0.7557 & 0.0040 & 0.3620 & 0.6552 & 1.0477 & 17,566 \\
\hline & Delta CoVaR & 0.0073 & 0.0000 & 0.0042 & 0.0063 & 0.0093 & 17,566 \\
\hline & Z-score & 44.6939 & 0.4390 & 9.3248 & 21.4279 & 53.2753 & 17,475 \\
\hline & CAPR & 14.7422 & 0.0518 & 12.1100 & 14.2100 & 16.8100 & 7694 \\
\hline & LVG & 29.1437 & 0.3090 & 6.4687 & 13.5834 & 33.1193 & 17,566 \\
\hline & MtB & 1.3411 & 0.0095 & 0.5569 & 0.9333 & 1.6470 & 17,477 \\
\hline & Misvaluation & 0.1498 & 0.0054 & -0.2376 & 0.0850 & 0.5456 & 17,426 \\
\hline & MV & 2380.14 & 44.5111 & 110.20 & 555.82 & 2416.29 & 17,566 \\
\hline & MV (centered) & 0.1292 & 0.0075 & -0.6024 & -0.1181 & 0.7476 & 17,566 \\
\hline
\end{tabular}

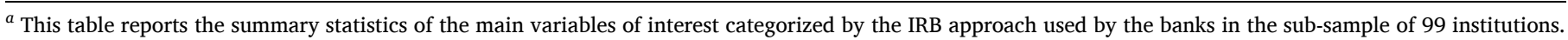

Table 8

Banks with internal models.

\begin{tabular}{|c|c|c|c|c|c|c|c|c|}
\hline Company Name & Country & IRBA & SRISK & Delta CoVaR & Z-score & Beta & MV & MtB \\
\hline Autobank & AUT & 1 & 23.041 & 0.001852581 & 68.4480896 & 0.418244481 & 13.05746841 & 0.515318871 \\
\hline Bank fur Tirol und Vorarlberg & AUT & 3 & 234.029 & 0.004863943 & 57.63896561 & 0.318704754 & 536.9927979 & 0.950202286 \\
\hline Erste Group Bank & AUT & 3 & 10919.071 & 0.013550359 & 27.25626564 & 1.208350539 & 13297.46191 & 1.279897809 \\
\hline Immigon Portfolioabbau & AUT & 1 & 4333.295 & 0.000619655 & 2.868360996 & 0.238174513 & 39.97393036 & 0.022140071 \\
\hline Oberbank & AUT & 1 & 207.406 & 0.00602958 & 122.115715 & 0.290880948 & 1294.011353 & 1.048346162 \\
\hline Raiffeisen Intern. Bank Holding & AUT & 3 & 3829.667 & 0.01428062 & 33.67729568 & 1.4791677 & 10237.65527 & 1.699620247 \\
\hline UniCredit Bank & AUT & 3 & 2485.126 & 0.006444126 & 18.54312897 & 0.608624697 & 19205.41797 & 1.600041628 \\
\hline Volksbank & AUT & 2 & 199.398 & 0.002114616 & 41.58185577 & 0.244797722 & 32.66580963 & 0.199353307 \\
\hline Wiener Privatbank & AUT & 1 & -46.749 & 0.002261561 & 13.40207863 & 0.172883973 & 69.7926712 & 1.387899041 \\
\hline Dexia & BEL & 1 & 36550.840 & 0.003969931 & 11.26284027 & 1.133173108 & 11356.44727 & 0.918165982 \\
\hline KBC Group & BEL & 3 & 13569.836 & 0.012023639 & 19.17169571 & 1.175006151 & 19918.9668 & 2.863557816 \\
\hline Banque Cantonale Vaudoise & CHE & 1 & 93.729 & 0.007376321 & 31.00448799 & 0.492326915 & 3173.183838 & 1.223238826 \\
\hline Bellevue Group & CHE & 1 & -269.136 & 0.007435598 & 14.96991539 & 0.444752932 & 410.6170349 & 1.715031624 \\
\hline Credit Suisse Group & CHE & 3 & 41318.988 & 0.013495322 & 17.7419796 & 1.145028234 & 40774.13281 & 1.303631783 \\
\hline Glarner Kantonalbank & CHE & 3 & 166.251 & 0.00225764 & 251.4246826 & 0.177800402 & 252.1076355 & 0.825312495 \\
\hline Luzerner Kantonalbank & CHE & 1 & -190.749 & 0.006635404 & 192.6670837 & 0.244047984 & 2404.594971 & 1.74032867 \\
\hline
\end{tabular}


Table 8 (continued)

\begin{tabular}{|c|c|c|c|c|c|c|c|c|}
\hline Company Name & Country & IRBA & SRISK & Delta CoVaR & Z-score & Beta & MV & MtB \\
\hline Thurgauer Kantonalbank & CHE & 1 & 1325.654 & 0.002293671 & 258.9310303 & 0.154421479 & 285.9465332 & 0.140479714 \\
\hline UBS Group & CHE & 3 & 57273.078 & 0.01496035 & 19.4371357 & 1.128180981 & 59205.32813 & 1.687543154 \\
\hline VZ Holding & CHE & 1 & -706.296 & 0.008132474 & 13.11054039 & 0.480005682 & 1110.495361 & 5.684613228 \\
\hline Aareal Bank & DEU & 3 & 3403.045 & 0.013246361 & 38.98952103 & 1.285407305 & 1495.167969 & 0.621584356 \\
\hline Albis Leasing & DEU & 1 & 52.682 & 0.002694323 & 3.007898569 & 0.470858097 & 38.0227356 & 2.124166012 \\
\hline Baader Bank & DEU & 1 & -86.570 & 0.007239574 & 23.81607819 & 0.811124325 & 193.1775208 & 1.118269563 \\
\hline Berliner Effektengesellschaft & DEU & 1 & -105.909 & 0.004835101 & 25.52674103 & 0.570054889 & 162.8542786 & 4.009314537 \\
\hline Comdirect Bank & DEU & 3 & 114.087 & 0.009639773 & 57.23443604 & 0.909302294 & 1497.35022 & 2.810607433 \\
\hline Commerzbank & DEU & 3 & 45573.902 & 0.012304731 & 40.9186554 & 1.344037533 & 13014.90137 & 0.70072341 \\
\hline Deutsche Bank & DEU & 3 & 117268.156 & 0.014660357 & 28.43572044 & 1.377972484 & 39179.44922 & 1.043306351 \\
\hline Deutsche Hypothekenbank & DEU & 1 & 2871.346 & 0.004473527 & 47.04047775 & 0.254683971 & 535.7086182 & 0.82724154 \\
\hline Deutsche Pfandbriefbank & DEU & 3 & 3865.717 & 0.003315037 & 17.97112465 & 0.551209152 & 566.2906494 & 0.542690694 \\
\hline Grenke & DEU & 1 & -559.290 & 0.008362943 & 144.5006104 & 0.761498928 & 1160.34668 & 2.829248428 \\
\hline HSBC Trinkaus \& Burkhardt & DEU & 2 & -481.600 & 0.004143512 & 115.561821 & 0.324846148 & 3083.888428 & 2.29980731 \\
\hline Hypo Real Estate Holding & DEU & 1 & 25885.676 & 0.00945323 & 7.34711647 & 1.169630885 & 5010.333008 & 1.241012454 \\
\hline IKB Deutsche Industriebank & DEU & 1 & 2478.336 & 0.004793256 & 6.4001894 & 0.68090111 & 1054.213745 & 0.750313699 \\
\hline Landesbank Berlin Holding & DEU & 1 & 9586.322 & 0.004991849 & 9.662435532 & 0.506529748 & 5154.123047 & 1.683634043 \\
\hline Merkur Bank & DEU & 1 & 51.134 & 0.00497785 & 78.7897644 & 0.314741611 & 34.37699127 & 0.567407727 \\
\hline Net-M Privatbank 1891 & DEU & 1 & -2.124 & 0.004034504 & 2.21822834 & 0.406870693 & 10.83274174 & 2.665394306 \\
\hline Oldenburgische Landesbank & DEU & 3 & 132.606 & 0.004861035 & 57.57830429 & 0.286489248 & 1191.303467 & 1.867131829 \\
\hline Quirin Privatbank & DEU & 1 & -34.035 & 0.008590111 & 23.63336945 & 0.450006068 & 99.3963623 & 1.906875968 \\
\hline BBVA & ESP & 3 & 18840.369 & 0.013812874 & 41.48424149 & 1.248331308 & 46506.73438 & 1.774502039 \\
\hline Banco De Sabadell & ESP & 3 & 5265.362 & 0.012423779 & 57.59740067 & 0.983117819 & 8482.126953 & 1.250335217 \\
\hline Banco Guipuzcoano & ESP & 3 & -87.433 & 0.007320781 & 54.31272125 & 0.446093559 & 1269.119141 & 1.980062962 \\
\hline Bankia & ESP & 3 & 17385.393 & 0.002680334 & 6.023930073 & 1.455013752 & 12322.42383 & 0.831365228 \\
\hline Bankinter & ESP & 3 & 1779.991 & 0.011388439 & 62.59482574 & 1.057143211 & 4316.850098 & 1.848767877 \\
\hline Caixabank & ESP & 3 & 5045.877 & 0.016968776 & 33.01026154 & 1.094476104 & 20657.65234 & 0.867110908 \\
\hline Liberbank & ESP & 1 & 3315.326 & 0.007227283 & 7.334450722 & 1.237219334 & 1521.582153 & 0.591811538 \\
\hline Aktia Bank & FIN & 3 & 695.143 & 0.011340129 & 62.98997116 & 0.557579279 & 485.1654358 & 0.728201091 \\
\hline Nordea Bank & FIN & 3 & 28336.531 & 0.014689432 & 93.36885071 & 1.206091285 & 35798.41016 & 1.420097351 \\
\hline BNP Paribas & FRA & 3 & 111763.102 & 0.014243565 & 40.85964584 & 1.363934636 & 60769.00781 & 1.038239241 \\
\hline Boursorama & FRA & 3 & -251.601 & 0.007744845 & 35.66352463 & 0.766729891 & 800.8115845 & 1.466428399 \\
\hline CRCAM Ille et Vilaine & FRA & 2 & 633.499 & 0.007740303 & 126.2689972 & 0.358111501 & 173.5814056 & 0.143920138 \\
\hline CRCAM Touraine et Poitou & FRA & 1 & 705.949 & 0.007534365 & 206.5726166 & 0.335144967 & 108.1418686 & 0.081288323 \\
\hline CRCAM Morbihan & FRA & 3 & 572.215 & 0.007838781 & 81.29877472 & 0.378207535 & 124.3241272 & 0.143890679 \\
\hline CRCAM Nord De France & FRA & 1 & 1689.307 & 0.008329921 & 92.31556702 & 0.397599339 & 375.8135376 & 0.138689458 \\
\hline CRCAM Atlantique Vendee & FRA & 2 & 1231.210 & 0.009426761 & 199.941803 & 0.428981066 & 153.2693481 & 0.061744865 \\
\hline CRCAM Brie Picardie & FRA & 2 & 1461.694 & 0.012603469 & 249.2119751 & 0.489549041 & 438.3301392 & 0.128955618 \\
\hline Credit Agricole & FRA & 3 & 122368.195 & 0.015177063 & 41.97698975 & 1.394251585 & 38105.37109 & 0.793215394 \\
\hline Natixis & FRA & 3 & 28825.768 & 0.011248422 & 25.00579453 & 1.142300844 & 12074.8418 & 0.873718977 \\
\hline Rothschild and Co & FRA & 1 & -217.783 & 0.00741158 & 20.70699692 & 0.522792101 & 953.4487915 & 0.958823979 \\
\hline Societe Generale Group & FRA & 3 & 70604.711 & 0.013450509 & 39.96392441 & 1.402905822 & 35636.78906 & 1.05896461 \\
\hline Barclays & GBR & 3 & 102335.461 & 0.01305501 & 24.11451149 & 1.327796698 & 46929.80078 & 1.244517565 \\
\hline HSBC Holdings & GBR & 3 & 26576.365 & 0.006455679 & 48.89240646 & 0.408925146 & 139454.2031 & 1.409381986 \\
\hline Investec & GBR & 1 & 2758.923 & 0.015428014 & 83.57341766 & 1.178666949 & 3512.855957 & 0.910325408 \\
\hline Lloyds Banking Group & GBR & 3 & 40050.313 & 0.012243764 & 21.34240913 & 1.176640749 & 47021.04297 & 1.810645223 \\
\hline Nationwide Building Society & GBR & 3 & 22941.590 & 0.005071634 & 127.6891632 & 0.284092665 & 1265.695068 & 0.080044627 \\
\hline Royal Bank of Scotland Group & GBR & 3 & 98711.773 & 0.012929882 & 12.72560787 & 1.262645245 & 42726.91797 & 0.993457973 \\
\hline Secure Trust Bank & GBR & 1 & -298.515 & 0.00416484 & 34.68941498 & 0.395602733 & 526.3799438 & 3.918032885 \\
\hline Standard Chartered & GBR & 3 & 11112.492 & 0.01176663 & 34.05759811 & 1.195171356 & 31590.29688 & 1.664121032 \\
\hline Alpha Bank & GRC & 3 & 1820.731 & 0.007607359 & 7.694550514 & 1.134265423 & 6049.511719 & 1.613457441 \\
\hline Attica Bank & GRC & 1 & 135.648 & 0.005034237 & 6.440349102 & 1.036868095 & 382.8707886 & 1.549787998 \\
\hline Eurobank Ergasias & GRC & 3 & 2517.655 & 0.006865981 & 7.082958698 & 1.203996778 & 6124.986328 & 1.553241134 \\
\hline National Bank of Greece & GRC & 3 & 2632.854 & 0.007906822 & 4.167312622 & 1.149781227 & 9143.253906 & 1.667377949 \\
\hline Piraeus Bank & GRC & 1 & 2514.644 & 0.007418145 & 4.406926155 & 1.29040122 & 4295.94873 & 1.600987196 \\
\hline Depfa Bank & IRL & 1 & 16609.684 & 0.006191196 & 12.28033829 & 0.876071215 & 5258.584961 & 1.827822685 \\
\hline Banca Carige & ITA & 1 & 827.011 & 0.009174598 & 19.00630188 & 0.851867914 & 3101.825195 & 0.885173678 \\
\hline Banca Finnat Euramerica & ITA & 1 & -82.687 & 0.006259681 & 4.078624249 & 0.670528829 & 204.2036591 & 1.30452168 \\
\hline Banca Generali & ITA & 1 & -459.398 & 0.01523415 & 24.39142036 & 1.109371424 & 1881.590576 & 4.023583889 \\
\hline Banca Ifis & ITA & 1 & -43.071 & 0.009486132 & 10.19067383 & 0.71671325 & 633.086731 & 2.440440655 \\
\hline BIM & ITA & 1 & -286.922 & 0.00436037 & 8.178188324 & 0.541989148 & 776.6318359 & 1.881037354 \\
\hline Banca Mediolanum & ITA & 1 & 354.375 & 0.012913267 & 24.69230843 & 1.290639639 & 4900.019043 & 4.903009892 \\
\hline Banca Monte Dei Paschi Di Siena & ITA & 3 & 12934.268 & 0.009841322 & 8.61127758 & 1.225691438 & 8121.392578 & 0.79960829 \\
\hline Banca Popolare Di Sondrio & ITA & 1 & 452.889 & 0.008347902 & 57.51979065 & 0.694822788 & 2562.26416 & 181.2174225 \\
\hline Banca Profilo & ITA & 1 & 17.217 & 0.00750115 & 13.54557037 & 0.969615519 & 276.2577515 & 1.890980124 \\
\hline Banco BPM & ITA & 3 & 7114.547 & 0.011691041 & 13.22085762 & 1.246133447 & 5936.673828 & 23.97793579 \\
\hline Banco Di Desio E Della Brianza & ITA & 3 & 358.429 & 0.008979498 & 28.41855812 & 0.696234822 & 633.4046021 & 1.031785727 \\
\hline Bper Banca & ITA & 3 & 2793.396 & 0.010112206 & 50.70727921 & 0.979093373 & 3356.854004 & 1.012470007 \\
\hline Conafi & ITA & 1 & -51.040 & 0.006688542 & 17.57960129 & 0.729406893 & 84.99110413 & 1.818447828 \\
\hline Credito Emiliano & ITA & 3 & 1397.438 & 0.01182472 & 59.3552742 & 1.038125157 & 2410.925781 & 1.31563127 \\
\hline Credito Valtellinese & ITA & 1 & 1276.292 & 0.008885185 & 21.13791275 & 0.875893176 & 1097.975098 & 0.711254954 \\
\hline FinecoBank & ITA & 1 & -401.490 & 0.008967301 & 58.2365036 & 1.105085611 & 4099.073242 & 5.667462826 \\
\hline Intesa Sanpaolo & ITA & 3 & 25246.189 & 0.011229392 & 22.40800095 & 1.211993456 & 35685.78516 & 1.061222076 \\
\hline Mediobanca & ITA & 1 & -29.649 & 0.010730479 & 43.71440125 & 1.137183785 & 8707.0625 & 1.608720541 \\
\hline Unicredit & ITA & 3 & 45303.094 & 0.01227919 & 12.98951149 & 1.304559827 & 39050.91797 & 1.039805412 \\
\hline Unione Di Banche Italiane & ITA & 3 & 5923.993 & 0.01280013 & 25.64300919 & 1.208103418 & 7841.083496 & 0.809497237 \\
\hline
\end{tabular}


Table 8 (continued)

\begin{tabular}{|c|c|c|c|c|c|c|c|c|}
\hline Company Name & Country & IRBA & SRISK & Delta CoVaR & Z-score & Beta & MV & MtB \\
\hline ABN Amro Holding & NLD & 1 & 31265.100 & 0.00908393 & 3.781084776 & 0.920505941 & 39869.73828 & 1.802146077 \\
\hline Binckbank & NLD & 1 & -125.707 & 0.006983061 & 49.9913826 & 1.020031452 & 627.2797852 & 2.352247 \\
\hline ING Groep & NLD & 3 & 67360.836 & 0.014527705 & 33.31870651 & 1.39409709 & 45837.81641 & 1.188655019 \\
\hline Kas-Bank & NLD & 2 & 416.199 & 0.007873039 & 31.88780594 & 0.585314691 & 283.2165527 & 1.144174218 \\
\hline Van LanschotKempen & NLD & 1 & 918.070 & 0.009393796 & 42.12671661 & 0.510897398 & 1066.565186 & 0.70769906 \\
\hline Banco Bpi SA & PRT & 1 & 1570.434 & 0.009141952 & 18.87298775 & 0.760675848 & 2389.163086 & 1.563182116 \\
\hline Banco Comercial Portugues & PRT & 3 & 3813.367 & 0.009778232 & 21.27783012 & 0.976748407 & 6427.01709 & 1.528923869 \\
\hline
\end{tabular}

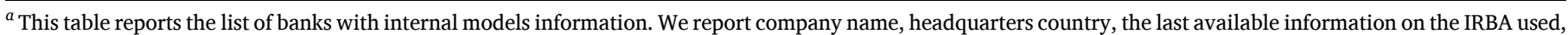
average SRISK market Beta, Delta CoVaR, Market capitalization and BtM of each bank.

Table 9

Unconditional quantile regressions of SRISK: year effects.

\begin{tabular}{|c|c|c|c|c|c|c|}
\hline VARIABLES & $\begin{array}{l}(1) \\
\text { Q.25 }\end{array}$ & $\begin{array}{l}(2) \\
Q .5\end{array}$ & $\begin{array}{l}(3) \\
\text { Q.75 }\end{array}$ & $\begin{array}{l}(4) \\
Q .25\end{array}$ & $\begin{array}{l}(5) \\
Q .5\end{array}$ & $\begin{array}{l}(6) \\
Q .75\end{array}$ \\
\hline L.SRISK & $\begin{array}{l}0.00544^{* * *} \\
(0.000225)\end{array}$ & $\begin{array}{l}0.0103^{* * *} \\
(0.000536)\end{array}$ & $\begin{array}{l}0.356^{* * *} \\
(0.00542)\end{array}$ & $\begin{array}{l}0.00509^{* * *} \\
(0.000222)\end{array}$ & $\begin{array}{l}0.00932^{* * *} \\
(0.000531)\end{array}$ & $\begin{array}{l}0.352^{* * *} \\
(0.00540)\end{array}$ \\
\hline Beta & $\begin{array}{l}332.0^{* * *} \\
(12.43)\end{array}$ & $\begin{array}{l}2213^{* * *} \\
(34.55)\end{array}$ & $\begin{array}{l}9118^{* * *} \\
(204.7)\end{array}$ & $\begin{array}{l}361.8^{* * *} \\
(12.59)\end{array}$ & $\begin{array}{l}2278^{* * * *} \\
(35.38)\end{array}$ & $\begin{array}{l}9446 * * * \\
(207.4)\end{array}$ \\
\hline Z-score & $\begin{array}{l}-1.877^{* * *} \\
(0.140)\end{array}$ & $\begin{array}{l}-3.590^{* * *} \\
(0.247)\end{array}$ & $\begin{array}{l}-60.69^{* * * *} \\
(1.122)\end{array}$ & $\begin{array}{l}-1.922^{* * *} \\
(0.139)\end{array}$ & $\begin{array}{l}-3.900^{* * *} \\
(0.251)\end{array}$ & $\begin{array}{l}-61.21^{* * *} \\
(1.142)\end{array}$ \\
\hline LVG & $\begin{array}{l}16.21 * * * \\
(0.223)\end{array}$ & $\begin{array}{l}33.09 * * * \\
(0.393)\end{array}$ & $\begin{array}{l}86.19^{* * *} \\
(2.923)\end{array}$ & $\begin{array}{l}16.78 * * * \\
(0.223)\end{array}$ & $\begin{array}{l}34.58^{* * *} \\
(0.391)\end{array}$ & $\begin{array}{l}92.48^{* * * *} \\
(2.984)\end{array}$ \\
\hline G-SIB FE & $\begin{array}{l}694.1^{* * *} \\
(17.81)\end{array}$ & $\begin{array}{l}2236^{* * * *} \\
(36.88)\end{array}$ & $\begin{array}{l}22,920 * * * \\
(326.8)\end{array}$ & $\begin{array}{l}703.9 * * * \\
(17.62)\end{array}$ & $\begin{array}{l}2281 * * * \\
(36.47)\end{array}$ & $\begin{array}{l}23,031^{* * *} \\
(325.3)\end{array}$ \\
\hline G-SIB & $\begin{array}{l}-583.6^{* * *} \\
(20.58)\end{array}$ & $\begin{array}{l}-966.3^{* * *} \\
(48.43)\end{array}$ & $\begin{array}{l}-1692^{* * *} \\
(485.6)\end{array}$ & $\begin{array}{l}-596.5^{* * *} \\
(20.34)\end{array}$ & $\begin{array}{l}-1011^{* * *} \\
(47.60)\end{array}$ & $\begin{array}{l}-1836^{* * *} \\
(480.9)\end{array}$ \\
\hline CISS & $\begin{array}{l}-217.3^{* * *} \\
(67.53)\end{array}$ & $\begin{array}{l}36.11 \\
(126.6)\end{array}$ & $\begin{array}{l}6329 * * * \\
(918.5)\end{array}$ & $\begin{array}{l}-85.56 \\
(67.79)\end{array}$ & $\begin{array}{l}391.2^{* * *} \\
(127.2)\end{array}$ & $\begin{array}{l}7786^{* * *} \\
(918.4)\end{array}$ \\
\hline Market Return & $\begin{array}{l}716.6 \\
(874.8)\end{array}$ & $\begin{array}{l}2949^{*} \\
(1662)\end{array}$ & $\begin{array}{l}14,829 \\
(11,786)\end{array}$ & $\begin{array}{l}610.6 \\
(871.5)\end{array}$ & $\begin{array}{l}2755^{*} \\
(1660)\end{array}$ & $\begin{array}{l}13,668 \\
(11,738)\end{array}$ \\
\hline ST interest rates & $\begin{array}{l}-90.84^{* * * *} \\
(7.193)\end{array}$ & $\begin{array}{l}-79.00^{* * * *} \\
(12.49)\end{array}$ & $\begin{array}{l}-368.7^{* * * *} \\
(56.79)\end{array}$ & $\begin{array}{l}-91.30^{* * * *} \\
(7.189)\end{array}$ & $\begin{array}{l}-78.19^{* * * *} \\
(12.41)\end{array}$ & $\begin{array}{l}-373.4 * * * \\
(56.77)\end{array}$ \\
\hline ECB Mon. Policy Assets & $\begin{array}{l}-0.000396 * * * \\
(2.90 \mathrm{e}-05)\end{array}$ & $\begin{array}{l}-0.000544 * * * \\
(5.64 \mathrm{e}-05)\end{array}$ & $\begin{array}{l}0.00450 * * * \\
(0.000346)\end{array}$ & $\begin{array}{l}-0.000350^{* * * *} \\
(3.06 \mathrm{e}-05)\end{array}$ & $\begin{array}{l}-0.000220 * * * \\
(5.88 \mathrm{e}-05)\end{array}$ & $\begin{array}{l}0.00504^{* * *} \\
(0.000363)\end{array}$ \\
\hline Misvaluation & $\begin{array}{l}-787.1^{* * *} \\
(13.17)\end{array}$ & $\begin{array}{l}-579.4^{* * *} \\
(18.83)\end{array}$ & $\begin{array}{l}144.1 \\
(104.7)\end{array}$ & $\begin{array}{l}-783.9^{* * *} \\
(13.25)\end{array}$ & $\begin{array}{l}-564.2^{* * *} \\
(18.64)\end{array}$ & $\begin{array}{l}180.6^{*} \\
(104.4)\end{array}$ \\
\hline MV (centered) & $\begin{array}{l}-31.00 * * * \\
(7.347)\end{array}$ & $\begin{array}{l}305.4^{* * *} \\
(12.45)\end{array}$ & $\begin{array}{l}3134 * * * \\
(84.76)\end{array}$ & $\begin{array}{l}-128.3^{* * *} \\
(12.00)\end{array}$ & $\begin{array}{l}-109.8^{* * *} \\
(20.02)\end{array}$ & $\begin{array}{l}2037 * * * \\
(145.3)\end{array}$ \\
\hline IRBA-S/F & $\begin{array}{l}108.2^{* *} \\
(55.15)\end{array}$ & $\begin{array}{l}-166.2^{*} \\
(89.05)\end{array}$ & $\begin{array}{l}-908.1 * \\
(547.2)\end{array}$ & $\begin{array}{l}68.29 \\
(58.47)\end{array}$ & $\begin{array}{l}-693.7^{* * *} \\
(93.96)\end{array}$ & $\begin{array}{l}-1405^{* *} \\
(579.8)\end{array}$ \\
\hline IRBA-A/M & $\begin{array}{l}793.9^{* * *} \\
(57.07)\end{array}$ & $\begin{array}{l}1563^{* * *} \\
(94.87)\end{array}$ & $\begin{array}{l}11,099 * * * \\
(601.3)\end{array}$ & $\begin{array}{l}681.9^{* * *} \\
(60.34)\end{array}$ & $\begin{array}{l}916.8^{* * *} \\
(99.80)\end{array}$ & $\begin{array}{l}9815^{* * *} \\
(636.4)\end{array}$ \\
\hline IRBA-S/F \# MV & & & & $\begin{array}{l}54.15^{* * *} \\
(15.80)\end{array}$ & $\begin{array}{l}525.9^{* * *} \\
(26.59)\end{array}$ & $\begin{array}{l}648.9^{* * *} \\
(176.2)\end{array}$ \\
\hline IRBA-A/M \# MV & & & & $\begin{array}{l}375.8^{* * *} \\
(15.73)\end{array}$ & $\begin{array}{l}894.5^{* * *} \\
(32.90)\end{array}$ & $\begin{array}{l}4141^{* * *} \\
(291.2)\end{array}$ \\
\hline Year effects & yes & yes & yes & yes & yes & yes \\
\hline Country effects & yes & yes & yes & yes & yes & yes \\
\hline Constant & $\begin{array}{l}664.6^{* * *} \\
(65.99)\end{array}$ & $\begin{array}{l}-1091 * * * \\
(144.3)\end{array}$ & $\begin{array}{l}-23,297^{* * *} \\
(882.9)\end{array}$ & $\begin{array}{l}483.8^{* * *} \\
(67.95)\end{array}$ & $\begin{array}{l}-1789 * * * \\
(146.4)\end{array}$ & $\begin{array}{l}-25,325^{* * *} \\
(904.1)\end{array}$ \\
\hline Observations & 98,211 & 98,211 & 98,211 & 98,211 & 98,211 & 98,211 \\
\hline Number of id & 99 & 99 & 99 & 99 & 99 & 99 \\
\hline R-squared & 0.359 & 0.474 & 0.595 & 0.362 & 0.478 & 0.597 \\
\hline RMSE & 1520 & 2853 & 21367 & 1516 & 2843 & 21331 \\
\hline Norm.RMSE & 74.94 & 2.68 & 2.37 & 74.75 & 2.67 & 2.37 \\
\hline
\end{tabular}

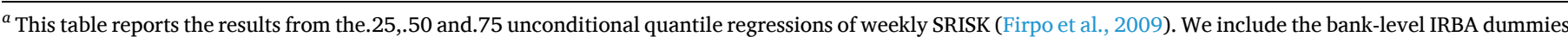

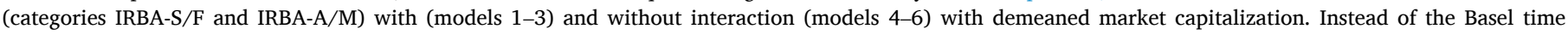

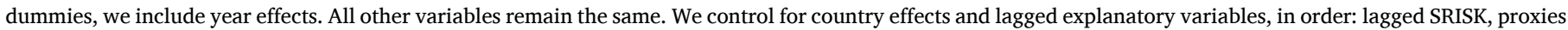

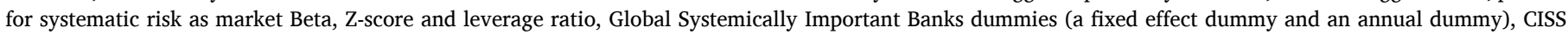

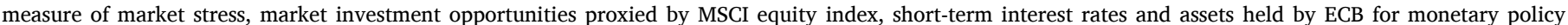

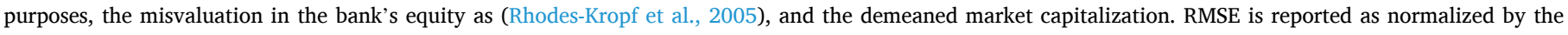
respective percentile. Robust standard errors in parentheses. ${ }^{* * *} \mathrm{p}<0.01,{ }^{* *} \mathrm{p}<0.05,{ }^{*} \mathrm{p}<0.1$. 
Table 10

Unconditional quantile regressions of SRISK: macro country variables.

\begin{tabular}{|c|c|c|c|c|c|c|}
\hline VARIABLES & $\begin{array}{l}(1) \\
\text { Q.25 }\end{array}$ & $\begin{array}{l}(2) \\
Q .5\end{array}$ & $\begin{array}{l}(3) \\
\text { Q.75 }\end{array}$ & $\begin{array}{l}\text { (4) } \\
\text { Q.25 }\end{array}$ & $\begin{array}{l}(5) \\
\text { Q.5 }\end{array}$ & $\begin{array}{l}(6) \\
Q .75\end{array}$ \\
\hline L.SRISK & $\begin{array}{l}-0.00178 \\
(0.00217)\end{array}$ & $\begin{array}{l}-0.00574 * \\
(0.00291)\end{array}$ & $\begin{array}{l}0.200 \\
(0.124)\end{array}$ & $\begin{array}{l}-0.00192 \\
(0.00213)\end{array}$ & $\begin{array}{l}-0.00571 * \\
(0.00292)\end{array}$ & $\begin{array}{l}0.197 \\
(0.124)\end{array}$ \\
\hline Beta & $\begin{array}{l}113.9 \\
(98.20)\end{array}$ & $\begin{array}{l}571.2^{* * *} \\
(104.1)\end{array}$ & $\begin{array}{l}5599 * * * \\
(1933)\end{array}$ & $\begin{array}{l}106.8 \\
(101.9)\end{array}$ & $\begin{array}{l}552.0^{* * *} \\
(105.2)\end{array}$ & $\begin{array}{l}5745^{* * *} \\
(1868)\end{array}$ \\
\hline Z-score & $\begin{array}{l}-8.545^{* * *} \\
(2.612)\end{array}$ & $\begin{array}{l}-3.903 \\
(2.741)\end{array}$ & $\begin{array}{l}-21.86 \\
(25.16)\end{array}$ & $\begin{array}{l}-8.848^{* * *} \\
(2.586)\end{array}$ & $\begin{array}{l}-4.103 \\
(2.701)\end{array}$ & $\begin{array}{l}-23.75 \\
(24.63)\end{array}$ \\
\hline LVG & $\begin{array}{l}-2.732 \\
(3.437)\end{array}$ & $\begin{array}{l}5.287 \\
(4.406)\end{array}$ & $\begin{array}{l}38.39 \\
(35.65)\end{array}$ & $\begin{array}{l}-2.553 \\
(3.472)\end{array}$ & $\begin{array}{l}4.996 \\
(4.374)\end{array}$ & $\begin{array}{l}44.84 \\
(36.12)\end{array}$ \\
\hline G-SIB FE & & & & & & \\
\hline G-SIB & $\begin{array}{l}-676.4^{* * *} \\
(170.2)\end{array}$ & $\begin{array}{l}-757.9 * * * \\
(208.0)\end{array}$ & $\begin{array}{l}-1136 \\
(5372)\end{array}$ & $\begin{array}{l}-666.3^{* * *} \\
(172.8)\end{array}$ & $\begin{array}{l}-753.6^{* * *} \\
(207.8)\end{array}$ & $\begin{array}{l}-1043 \\
(5326)\end{array}$ \\
\hline CISS & $\begin{array}{l}316.2 \\
(231.1)\end{array}$ & $\begin{array}{l}724.9 * * * \\
(274.3)\end{array}$ & $\begin{array}{l}363.1 \\
(2793)\end{array}$ & $\begin{array}{l}249.3 \\
(229.5)\end{array}$ & $\begin{array}{l}674.6^{* * *} \\
(263.3)\end{array}$ & $\begin{array}{l}29.35 \\
(2774)\end{array}$ \\
\hline Market Return & $\begin{array}{l}435.7 \\
(566.9)\end{array}$ & $\begin{array}{l}-503.7 \\
(827.3)\end{array}$ & $\begin{array}{l}16,485^{* *} \\
(6768)\end{array}$ & $\begin{array}{l}358.7 \\
(570.1)\end{array}$ & $\begin{array}{l}-609.4 \\
(809.3)\end{array}$ & $\begin{array}{l}16,729 * * \\
(6494)\end{array}$ \\
\hline ST interest rates & $\begin{array}{l}-123.4^{* * *} \\
(27.72)\end{array}$ & $\begin{array}{l}-72.34 * \\
(39.28)\end{array}$ & $\begin{array}{l}671.4^{*} \\
(362.2)\end{array}$ & $\begin{array}{l}-116.2^{* * *} \\
(28.44)\end{array}$ & $\begin{array}{l}-65.17 * \\
(39.19)\end{array}$ & $\begin{array}{l}684.4^{* *} \\
(339.1)\end{array}$ \\
\hline ECB Mon. Policy Assets & $\begin{array}{l}0.000135^{* * *} \\
(5.12 \mathrm{e}-05)\end{array}$ & $\begin{array}{l}0.000138^{* * *} \\
(4.99 \mathrm{e}-05)\end{array}$ & $\begin{array}{l}0.000709 \\
(0.000812)\end{array}$ & $\begin{array}{l}0.000134^{* * *} \\
(5.03 \mathrm{e}-05)\end{array}$ & $\begin{array}{l}0.000143^{* * *} \\
(4.88 \mathrm{e}-05)\end{array}$ & $\begin{array}{l}0.000630 \\
(0.000780)\end{array}$ \\
\hline Misvaluation & $\begin{array}{l}-453.3^{* * *} \\
(117.4)\end{array}$ & $\begin{array}{l}-317.8^{* * *} \\
(120.7)\end{array}$ & $\begin{array}{l}-2143 \\
(1386)\end{array}$ & $\begin{array}{l}-458.8^{* * *} \\
(120.6)\end{array}$ & $\begin{array}{l}-321.2^{* * *} \\
(121.3)\end{array}$ & $\begin{array}{l}-2180 \\
(1412)\end{array}$ \\
\hline MV (centered) & $\begin{array}{l}-327.4^{* * *} \\
(73.63)\end{array}$ & $\begin{array}{l}-30.78 \\
(86.66)\end{array}$ & $\begin{array}{l}1402 * \\
(823.9)\end{array}$ & $\begin{array}{l}-210.3^{* *} \\
(102.5)\end{array}$ & $\begin{array}{l}72.73 \\
(106.8)\end{array}$ & $\begin{array}{l}1783 \\
(1227)\end{array}$ \\
\hline IRBA-S/F & $\begin{array}{l}613.3^{* * *} \\
(131.3)\end{array}$ & $\begin{array}{l}595.3^{* * *} \\
(185.3)\end{array}$ & $\begin{array}{l}-89.63 \\
(1882)\end{array}$ & $\begin{array}{l}852.2^{* * *} \\
(194.6)\end{array}$ & $\begin{array}{l}771.1^{* * *} \\
(257.2)\end{array}$ & $\begin{array}{l}1151 \\
(2186)\end{array}$ \\
\hline IRBA-A/M & $\begin{array}{l}825.8^{* * *} \\
(257.3)\end{array}$ & $\begin{array}{l}796.9^{* * *} \\
(347.3)\end{array}$ & $\begin{array}{l}10,713^{* * *} \\
(4496)\end{array}$ & $\begin{array}{l}1013^{* * * *} \\
(313.3)\end{array}$ & $\begin{array}{l}975.7^{* *} \\
(388.7)\end{array}$ & $\begin{array}{l}11,147^{* *} \\
(4519)\end{array}$ \\
\hline IRBA-S/F \# MV & & & & $\begin{array}{l}-230.1 * \\
(126.6)\end{array}$ & $\begin{array}{l}-161.8 \\
(102.4)\end{array}$ & $\begin{array}{l}-1293 \\
(1306)\end{array}$ \\
\hline IRBA-A/M \# MV & & & & $\begin{array}{l}-24.17 \\
(138.3)\end{array}$ & $\begin{array}{l}-142.4 \\
(134.9)\end{array}$ & $\begin{array}{l}1506 \\
(2084)\end{array}$ \\
\hline Jan 1996- Jun2006 & $\begin{array}{l}-241.5 \\
(260.0)\end{array}$ & $\begin{array}{l}-161.9 \\
(402.5)\end{array}$ & $\begin{array}{l}28,480 \\
(21,313)\end{array}$ & $\begin{array}{l}-336.3 \\
(277.6)\end{array}$ & $\begin{array}{l}-245.7 \\
(406.3)\end{array}$ & $\begin{array}{l}28,172 \\
(21,190)\end{array}$ \\
\hline Jun2006- Sep2008 & $\begin{array}{l}-103.1 \\
(315.2)\end{array}$ & $\begin{array}{l}-314.8 \\
(428.5)\end{array}$ & $\begin{array}{l}25,985 \\
(21,758)\end{array}$ & $\begin{array}{l}-305.6 \\
(332.9)\end{array}$ & $\begin{array}{l}-498.4 \\
(429.8)\end{array}$ & $\begin{array}{l}25,386 \\
(21,678)\end{array}$ \\
\hline Sep2008- Sep2010 & $\begin{array}{l}-249.2 \\
(370.2)\end{array}$ & $\begin{array}{l}93.83 \\
(536.2)\end{array}$ & $\begin{array}{l}27,902 \\
(21,472)\end{array}$ & $\begin{array}{l}-552.2 \\
(401.0)\end{array}$ & $\begin{array}{l}-143.7 \\
(517.6)\end{array}$ & $\begin{array}{l}26,518 \\
(21,465)\end{array}$ \\
\hline Sep2010- Nov2014 & $\begin{array}{l}-147.8 \\
(374.9)\end{array}$ & $\begin{array}{l}139.7 \\
(544.5)\end{array}$ & $\begin{array}{l}30,429 \\
(21,435)\end{array}$ & $\begin{array}{l}-449.4 \\
(403.5)\end{array}$ & $\begin{array}{l}-100.4 \\
(527.0)\end{array}$ & $\begin{array}{l}29,101 \\
(21,411)\end{array}$ \\
\hline Nov2014- Dec2018 & $\begin{array}{l}-215.5 \\
(375.0)\end{array}$ & $\begin{array}{l}136.0 \\
(544.3)\end{array}$ & $\begin{array}{l}28,661 \\
(21,519)\end{array}$ & $\begin{array}{l}-514.0 \\
(405.2)\end{array}$ & $\begin{array}{l}-105.9 \\
(531.4)\end{array}$ & $\begin{array}{l}27,403 \\
(21,559)\end{array}$ \\
\hline L.HUR & $\begin{array}{l}59.32^{* *} \\
(23.77)\end{array}$ & $\begin{array}{l}164.9 * * * \\
(34.80)\end{array}$ & $\begin{array}{l}327.0 \\
(495.1)\end{array}$ & $\begin{array}{l}59.95^{* *} \\
(24.43)\end{array}$ & $\begin{array}{l}165.0 * * * \\
(35.03)\end{array}$ & $\begin{array}{l}334.4 \\
(491.9)\end{array}$ \\
\hline L.PPI & $\begin{array}{l}1.930 \\
(6.283)\end{array}$ & $\begin{array}{l}16.05^{*} \\
(8.693)\end{array}$ & $\begin{array}{l}-67.35 \\
(90.64)\end{array}$ & $\begin{array}{l}-0.149 \\
(6.197)\end{array}$ & $\begin{array}{l}13.76 \\
(8.512)\end{array}$ & $\begin{array}{l}-68.25 \\
(91.92)\end{array}$ \\
\hline L.QGDP & $\begin{array}{l}-64.74^{* *} \\
(27.37)\end{array}$ & $\begin{array}{l}-61.12 \\
(45.19)\end{array}$ & $\begin{array}{l}-207.2 \\
(451.2)\end{array}$ & $\begin{array}{l}-66.18 * * \\
(28.25)\end{array}$ & $\begin{array}{l}-59.74 \\
(45.32)\end{array}$ & $\begin{array}{l}-246.8 \\
(457.0)\end{array}$ \\
\hline Constant & $\begin{array}{l}-207.6 \\
(410.2)\end{array}$ & $\begin{array}{l}-1304 * * \\
(548.1)\end{array}$ & $\begin{array}{l}-32,964 \\
(21,932)\end{array}$ & $\begin{array}{l}-104.6 \\
(426.1)\end{array}$ & $\begin{array}{l}-1199 * * \\
(538.4)\end{array}$ & $\begin{array}{l}-32,805 \\
(21,880)\end{array}$ \\
\hline Firm Effects & yes ${ }^{* * *}$ & yes $* * *$ & yes $^{* * *}$ & yes ${ }^{* * *}$ & yes ${ }^{* * *}$ & yes**** \\
\hline Observations & 78,239 & 78,239 & 78,239 & 78,239 & 78,239 & 78,239 \\
\hline Number of id & 99 & 99 & 99 & 99 & 99 & 99 \\
\hline R-squared & 0.302 & 0.318 & 0.166 & 0.307 & 0.319 & 0.169 \\
\hline RMSE & 1137 & 1441 & 18175 & 1134 & 1440 & 18150 \\
\hline Norm.RMSE & 56.06 & 1.35 & 2.02 & 55.91 & 1.35 & 2.02 \\
\hline
\end{tabular}

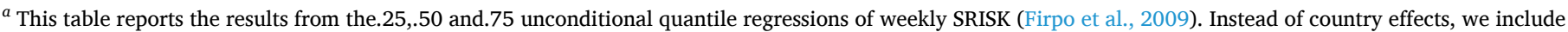

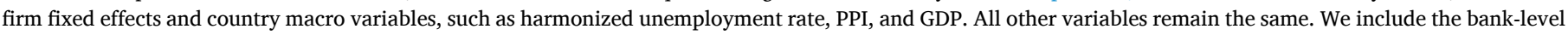

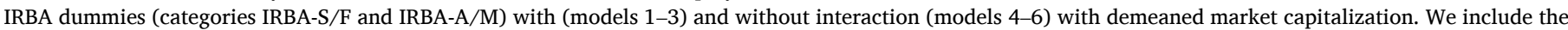

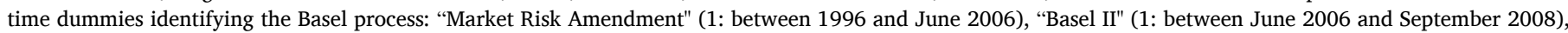

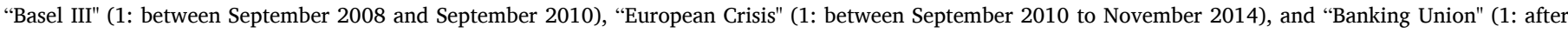

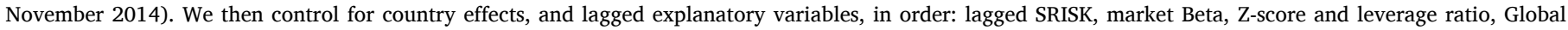

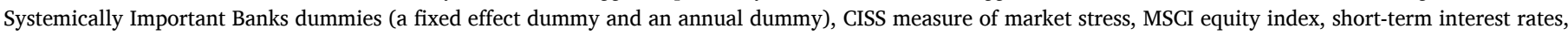

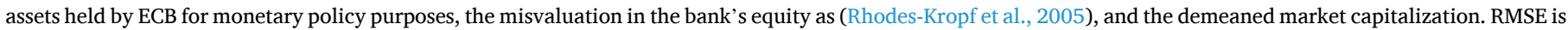
reported as normalized by the respective percentile. Robust standard errors in parentheses. ${ }^{* * *} \mathrm{p}<0.01,{ }^{* *} \mathrm{p}<0.05,{ }^{*} \mathrm{p}<0.1$. 
Table 11

Unconditional quantile regressions of SRISK: number of annual M\&A.

\begin{tabular}{|c|c|c|c|c|c|c|}
\hline & $\begin{array}{l}(1) \\
\text { Q.25 }\end{array}$ & $\begin{array}{l}(2) \\
\text { Q.5 }\end{array}$ & $\begin{array}{l}(3) \\
\text { Q.75 }\end{array}$ & $\begin{array}{l}\text { (4) } \\
\text { Q.25 }\end{array}$ & $\begin{array}{l}\text { (5) } \\
\text { Q.5 }\end{array}$ & $\begin{array}{l}\text { (6) } \\
\text { Q.75 }\end{array}$ \\
\hline L.SRISK & $\begin{array}{l}0.00527 * * * \\
(0.000222)\end{array}$ & $\begin{array}{l}0.0100^{* * *} \\
(0.000519)\end{array}$ & $\begin{array}{l}0.373^{* * *} \\
(0.00566)\end{array}$ & $\begin{array}{l}0.00488^{* * *} \\
(0.000219)\end{array}$ & $\begin{array}{l}0.00921^{* * *} \\
(0.000516)\end{array}$ & $\begin{array}{l}0.370 * * * \\
(0.00565)\end{array}$ \\
\hline Beta & $\begin{array}{l}309.4^{* * *} \\
(12.22)\end{array}$ & $\begin{array}{l}2093^{* * * *} \\
(32.68)\end{array}$ & $\begin{array}{l}9073^{* * *} \\
(208.6)\end{array}$ & $\begin{array}{l}355.8^{* * *} \\
(12.47)\end{array}$ & $\begin{array}{l}2190 * * * \\
(33.94)\end{array}$ & $\begin{array}{l}9511^{* * *} \\
(212.4)\end{array}$ \\
\hline Z-score & $\begin{array}{l}-2.116^{* * *} \\
(0.139)\end{array}$ & $\begin{array}{l}-3.963^{* * *} \\
(0.239)\end{array}$ & $\begin{array}{l}-62.25^{* * *} \\
(1.152)\end{array}$ & $\begin{array}{l}-2.138^{* * *} \\
(0.139)\end{array}$ & $\begin{array}{l}-4.083^{* * *} \\
(0.241)\end{array}$ & $\begin{array}{l}-62.41 * * * \\
(1.162)\end{array}$ \\
\hline LVG & $\begin{array}{l}15.95^{* * *} \\
(0.225)\end{array}$ & $\begin{array}{l}32.17 * * * \\
(0.380)\end{array}$ & $\begin{array}{l}90.02^{* * *} \\
(3.034)\end{array}$ & $\begin{array}{l}16.77^{* * *} \\
(0.225)\end{array}$ & $\begin{array}{l}34.01 * * * \\
(0.376)\end{array}$ & $\begin{array}{l}97.59^{* * *} \\
(3.102)\end{array}$ \\
\hline G-SIB FE & $\begin{array}{l}740.3^{* * *} \\
(18.01)\end{array}$ & $\begin{array}{l}2248^{* * * *} \\
(36.17)\end{array}$ & $\begin{array}{l}24,108^{* * *} \\
(346.4)\end{array}$ & $\begin{array}{l}743.6^{* * *} \\
(17.82)\end{array}$ & $\begin{array}{l}2259 * * * \\
(35.75)\end{array}$ & $\begin{array}{l}24,136 * * * \\
(344.9)\end{array}$ \\
\hline G-SIB & $\begin{array}{l}-598.4^{* * *} \\
(20.28)\end{array}$ & $\begin{array}{l}-989.2^{* * *} \\
(46.43)\end{array}$ & $\begin{array}{l}-1609 * * * \\
(503.9)\end{array}$ & $\begin{array}{l}-605.8 * * * \\
(19.97)\end{array}$ & $\begin{array}{l}-1017^{* * *} \\
(45.73)\end{array}$ & $\begin{array}{l}-1672^{* * *} \\
(500.1)\end{array}$ \\
\hline CISS & $\begin{array}{l}-178.0 * * * \\
(51.17)\end{array}$ & $\begin{array}{l}-229.4 * * \\
(90.14)\end{array}$ & $\begin{array}{l}2630 * * * \\
(689.5)\end{array}$ & $\begin{array}{l}-76.71 \\
(52.09)\end{array}$ & $\begin{array}{l}97.37 \\
(91.59)\end{array}$ & $\begin{array}{l}3506 * * * \\
(698.0)\end{array}$ \\
\hline Market Return & $\begin{array}{l}533.8 \\
(874.1)\end{array}$ & $\begin{array}{l}771.8 \\
(1620)\end{array}$ & $\begin{array}{l}-335.6 \\
(12,187)\end{array}$ & $\begin{array}{l}687.0 \\
(870.5)\end{array}$ & $\begin{array}{l}1066 \\
(1617)\end{array}$ & $\begin{array}{l}1123 \\
(12,147)\end{array}$ \\
\hline ST interest rates & $\begin{array}{l}-67.21 * * * \\
(4.445)\end{array}$ & $\begin{array}{l}-39.55^{* * *} \\
(7.692)\end{array}$ & $\begin{array}{l}-783.8^{* * *} \\
(58.27)\end{array}$ & $\begin{array}{l}-75.33 * * * \\
(4.666)\end{array}$ & $\begin{array}{l}-61.70^{* * *} \\
(8.201)\end{array}$ & $\begin{array}{l}-856.7^{* * *} \\
(60.43)\end{array}$ \\
\hline ECB Mon. Policy Assets & $\begin{array}{l}1.91 \mathrm{e}-05^{*} \\
(1.08 \mathrm{e}-05)\end{array}$ & $\begin{array}{l}-0.000103^{* * *} \\
(2.20 \mathrm{e}-05)\end{array}$ & $\begin{array}{l}0.000111 \\
(0.000169)\end{array}$ & $\begin{array}{l}1.26 \mathrm{e}-05 \\
(1.07 \mathrm{e}-05)\end{array}$ & $\begin{array}{l}-0.000104 * * * \\
(2.20 \mathrm{e}-05)\end{array}$ & $\begin{array}{l}4.18 \mathrm{e}-05 \\
(0.000169)\end{array}$ \\
\hline Misvaluation & $\begin{array}{l}-792.7^{* * *} \\
(13.21)\end{array}$ & $\begin{array}{l}-614.6^{* * *} \\
(18.09)\end{array}$ & $\begin{array}{l}-23.43 \\
(108.8)\end{array}$ & $\begin{array}{l}-786.8^{* * *} \\
(13.23)\end{array}$ & $\begin{array}{l}-598.8^{* * *} \\
(17.73)\end{array}$ & $\begin{array}{l}29.94 \\
(108.0)\end{array}$ \\
\hline Annual number of M\&A & $\begin{array}{l}-8.291 * * * \\
(0.523)\end{array}$ & $\begin{array}{l}-10.02^{* * *} \\
(0.909)\end{array}$ & $\begin{array}{l}-32.08^{* * *} \\
(7.106)\end{array}$ & $\begin{array}{l}-8.556^{* * *} \\
(0.519)\end{array}$ & $\begin{array}{l}-10.94 * * * \\
(0.901)\end{array}$ & $\begin{array}{l}-34.33^{* * *} \\
(7.105)\end{array}$ \\
\hline MV (centered) & $\begin{array}{l}-66.82 * * * \\
(6.965)\end{array}$ & $\begin{array}{l}278.2^{* * *} \\
(11.52)\end{array}$ & $\begin{array}{l}3133^{* * * *} \\
(83.64)\end{array}$ & $\begin{array}{l}-208.5^{* * *} \\
(10.55)\end{array}$ & $\begin{array}{l}-142.8 * * * \\
(17.22)\end{array}$ & $\begin{array}{l}1883^{* * *} \\
(128.6)\end{array}$ \\
\hline IRBA1/2 & $\begin{array}{l}274.6^{* * *} \\
(102.3)\end{array}$ & $\begin{array}{l}-218.6 \\
(158.3)\end{array}$ & $\begin{array}{l}-2156 * * \\
(999.6)\end{array}$ & $\begin{array}{l}98.99 \\
(104.7)\end{array}$ & $\begin{array}{l}-898.4^{* * *} \\
(159.8)\end{array}$ & $\begin{array}{l}-3600 * * * \\
(1016)\end{array}$ \\
\hline IRBA3 & $\begin{array}{l}967.3^{* * *} \\
(103.3)\end{array}$ & $\begin{array}{l}1488 * * * \\
(161.5)\end{array}$ & $\begin{array}{l}10,076^{* * *} \\
(1031)\end{array}$ & $\begin{array}{l}696.2^{* * *} \\
(105.8)\end{array}$ & $\begin{array}{l}655.1^{* * *} \\
(163.5)\end{array}$ & $\begin{array}{l}7701 * * * \\
(1051)\end{array}$ \\
\hline IRBA1/2 \# MV & & & & $\begin{array}{l}139.4^{* * *} \\
(14.45)\end{array}$ & $\begin{array}{l}590.8^{* * *} \\
(23.83)\end{array}$ & $\begin{array}{l}1112^{* * *} \\
(162.5)\end{array}$ \\
\hline IRBA3 \# MV & & & & $\begin{array}{l}463.4 * * * \\
(14.32)\end{array}$ & $\begin{array}{l}961.2^{* * *} \\
(30.13)\end{array}$ & $\begin{array}{l}4367 * * * \\
(288.2)\end{array}$ \\
\hline Jan1996- Jun2006 & $\begin{array}{l}-713.6^{* * *} \\
(30.39)\end{array}$ & $\begin{array}{l}-978.4^{* * *} \\
(60.31)\end{array}$ & $\begin{array}{l}4472^{* * * *} \\
(539.3)\end{array}$ & $\begin{array}{l}-625.8^{* * *} \\
(30.93)\end{array}$ & $\begin{array}{l}-709.5^{* * *} \\
(61.74)\end{array}$ & $\begin{array}{l}5241^{* * *} \\
(542.1)\end{array}$ \\
\hline Jun2006- Sep2008 & $\begin{array}{l}-1174 * * * \\
(105.1)\end{array}$ & $\begin{array}{l}-1420 * * * \\
(166.5)\end{array}$ & $\begin{array}{l}1155 \\
(1104)\end{array}$ & $\begin{array}{l}-933.6^{* * *} \\
(106.9)\end{array}$ & $\begin{array}{l}-709.1^{* * *} \\
(167.6)\end{array}$ & $\begin{array}{l}3277^{* * * *} \\
(1114)\end{array}$ \\
\hline Sep2008- Sep2010 & $\begin{array}{l}-1347^{* * *} \\
(112.7)\end{array}$ & $\begin{array}{l}-1445^{* * *} \\
(180.8)\end{array}$ & $\begin{array}{l}-2816 * * \\
(1236)\end{array}$ & $\begin{array}{l}-1113^{* * *} \\
(115.2)\end{array}$ & $\begin{array}{l}-600.5^{* * *} \\
(183.9)\end{array}$ & $\begin{array}{l}-851.3 \\
(1252)\end{array}$ \\
\hline Sep2010- Nov2014 & $\begin{array}{l}-1377^{* * *} \\
(111.5)\end{array}$ & $\begin{array}{l}-1579 * * * \\
(178.1)\end{array}$ & $\begin{array}{l}-780.9 \\
(1213)\end{array}$ & $\begin{array}{l}-1110 * * * \\
(114.4)\end{array}$ & $\begin{array}{l}-652.7 * * * \\
(181.5)\end{array}$ & $\begin{array}{l}1490 \\
(1228)\end{array}$ \\
\hline Nov2014- Dec2018 & $\begin{array}{l}-1416^{* * *} \\
(113.2)\end{array}$ & $\begin{array}{l}-1359 * * * \\
(182.0)\end{array}$ & $\begin{array}{l}-426.3 \\
(1243)\end{array}$ & $\begin{array}{l}-1156^{* * *} \\
(116.1)\end{array}$ & $\begin{array}{l}-456.1^{* * *} \\
(185.2)\end{array}$ & $\begin{array}{l}1777 \\
(1257)\end{array}$ \\
\hline Constant & $\begin{array}{l}790.4^{* * *} \\
(43.49)\end{array}$ & $\begin{array}{l}-941.3^{* * *} \\
(82.79)\end{array}$ & $\begin{array}{l}-8857 * * * \\
(643.1)\end{array}$ & $\begin{array}{l}648.0 * * * \\
(44.83)\end{array}$ & $\begin{array}{l}-1342^{* * *} \\
(85.65)\end{array}$ & $\begin{array}{l}-10,129^{* * * *} \\
(649.9)\end{array}$ \\
\hline Country Effects & yes & yes & yes & yes & yes & yes \\
\hline Year Effects & no & no & no & no & no & no \\
\hline Observations & 97,408 & 97,408 & 97,408 & 97,408 & 97,408 & 97,408 \\
\hline Number of banks & 99 & 99 & 99 & 99 & 99 & 99 \\
\hline R-squared & 0.352 & 0.467 & 0.595 & 0.358 & 0.473 & 0.596 \\
\hline RMSE & 1532 & 2803 & 22239 & 1526 & 2788 & 22200 \\
\hline Norm.RMSE & 75.54 & 2.63 & 2.47 & 75.24 & 2.62 & 2.47 \\
\hline
\end{tabular}

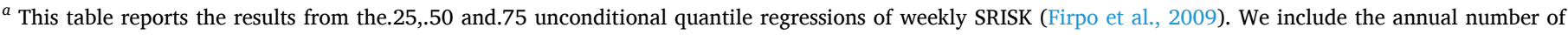

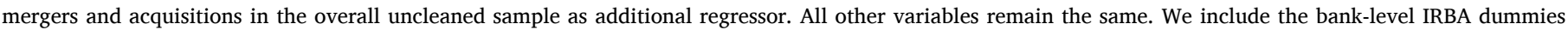

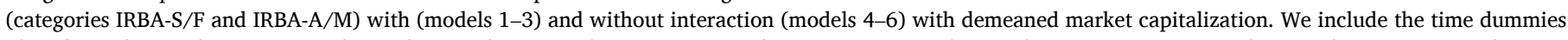

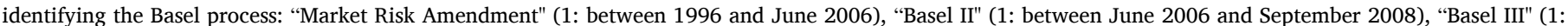

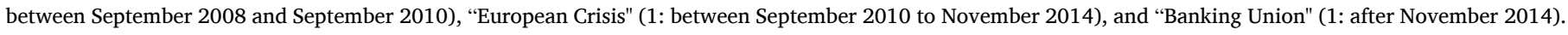

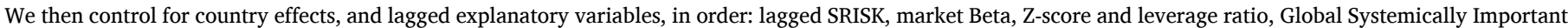

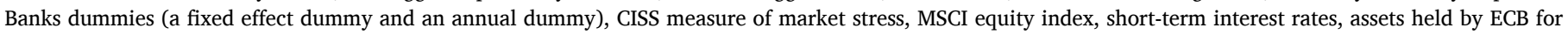

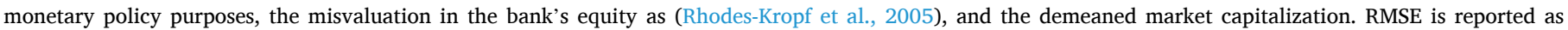
normalized by the respective percentile. Robust standard errors in parentheses. ${ }^{* * *} \mathrm{p}<0.01,{ }^{* *} \mathrm{p}<0.05,{ }^{*} \mathrm{p}<0.1$. 
Table 12

Unconditional quantile regressions of dollar delta CoVaR.

\begin{tabular}{|c|c|c|c|c|c|c|}
\hline & $\begin{array}{l}(1) \\
\text { Q.25 }\end{array}$ & $\begin{array}{l}(2) \\
Q .5\end{array}$ & $\begin{array}{l}\text { (3) } \\
\text { Q.75 }\end{array}$ & $\begin{array}{l}(4) \\
Q .25\end{array}$ & $\begin{array}{l}(5) \\
Q .5\end{array}$ & $\begin{array}{l}\text { (6) } \\
\text { Q.75 }\end{array}$ \\
\hline Z-score & $\begin{array}{l}0.0596^{* * *} \\
(0.00146)\end{array}$ & $\begin{array}{l}0.0419 * * * \\
(0.00248)\end{array}$ & $\begin{array}{l}-0.358^{* * *} \\
(0.0159)\end{array}$ & $\begin{array}{l}0.0586^{* * *} \\
(0.00144)\end{array}$ & $\begin{array}{l}0.0409 * * * \\
(0.00248)\end{array}$ & $\begin{array}{l}-0.344 * * * \\
(0.0151)\end{array}$ \\
\hline Beta & $\begin{array}{l}10.20^{* * *} \\
(0.140)\end{array}$ & $\begin{array}{l}31.08^{* * *} \\
(0.412)\end{array}$ & $\begin{array}{l}144.1 * * * \\
(2.932)\end{array}$ & $\begin{array}{l}10.19^{* * *} \\
(0.142)\end{array}$ & $\begin{array}{l}31.65^{* * *} \\
(0.422)\end{array}$ & $\begin{array}{l}149.0 * * * \\
(3.005)\end{array}$ \\
\hline SRISK & $\begin{array}{l}5.46 \mathrm{e}-06^{* * *} \\
(1.51 \mathrm{e}-06)\end{array}$ & $\begin{array}{l}1.62 \mathrm{e}-05^{* * *} \\
(4.39 \mathrm{e}-06)\end{array}$ & $\begin{array}{l}0.00246 * * * \\
(4.87 \mathrm{e}-05)\end{array}$ & $\begin{array}{l}5.88 \mathrm{e}-06^{* * *} \\
(1.52 \mathrm{e}-06)\end{array}$ & $\begin{array}{l}1.18 \mathrm{e}-05^{* * *} \\
(4.42 \mathrm{e}-06)\end{array}$ & $\begin{array}{l}0.00242 * * * \\
(4.88 \mathrm{e}-05)\end{array}$ \\
\hline LVG & $\begin{array}{l}-0.0852^{* * *} \\
(0.00194)\end{array}$ & $\begin{array}{l}-0.135^{* * *} \\
(0.00388)\end{array}$ & $\begin{array}{l}-1.246^{* * *} \\
(0.0305)\end{array}$ & $\begin{array}{l}-0.0837 * * * \\
(0.00200)\end{array}$ & $\begin{array}{l}-0.124 * * * \\
(0.00391)\end{array}$ & $\begin{array}{l}-1.192^{* * * *} \\
(0.0295)\end{array}$ \\
\hline G-SIB FE & $\begin{array}{l}5.885^{* * *} \\
(0.133)\end{array}$ & $\begin{array}{l}39.91 * * * \\
(0.380)\end{array}$ & $\begin{array}{l}526.0 * * * \\
(4.570)\end{array}$ & $\begin{array}{l}5.915^{* * *} \\
(0.132)\end{array}$ & $\begin{array}{l}39.96^{* * *} \\
(0.380)\end{array}$ & $\begin{array}{l}525.7 * * * \\
(4.556)\end{array}$ \\
\hline G-SIB & $\begin{array}{l}-0.550 * * * \\
(0.160)\end{array}$ & $\begin{array}{l}-6.383^{* * *} \\
(0.461)\end{array}$ & $\begin{array}{l}70.24 * * * \\
(4.918)\end{array}$ & $\begin{array}{l}-0.702^{* * *} \\
(0.157)\end{array}$ & $\begin{array}{l}-6.597 * * * \\
(0.463)\end{array}$ & $\begin{array}{l}72.03^{* * *} \\
(4.952)\end{array}$ \\
\hline CISS & $\begin{array}{l}6.995 * * * \\
(0.450)\end{array}$ & $\begin{array}{l}18.35^{* * *} \\
(0.991)\end{array}$ & $\begin{array}{l}183.8^{* * *} \\
(9.238)\end{array}$ & $\begin{array}{l}8.332^{* * *} \\
(0.455)\end{array}$ & $\begin{array}{l}20.54 * * * \\
(1.004)\end{array}$ & $\begin{array}{l}170.4^{* * *} \\
(9.231)\end{array}$ \\
\hline Market Return & $\begin{array}{l}19.76^{* *} \\
(8.304)\end{array}$ & $\begin{array}{l}15.87 \\
(18.63)\end{array}$ & $\begin{array}{l}98.55 \\
(171.0)\end{array}$ & $\begin{array}{l}19.66^{* *} \\
(8.279)\end{array}$ & $\begin{array}{l}17.95 \\
(18.65)\end{array}$ & $\begin{array}{l}117.1 \\
(170.0)\end{array}$ \\
\hline ST interest rates & $\begin{array}{l}0.110 * * * \\
(0.0310)\end{array}$ & $\begin{array}{l}-0.741^{* * *} \\
(0.0740)\end{array}$ & $\begin{array}{l}2.063^{* * *} \\
(0.680)\end{array}$ & $\begin{array}{l}0.0488 \\
(0.0313)\end{array}$ & $\begin{array}{l}-0.883^{* * *} \\
(0.0756)\end{array}$ & $\begin{array}{l}2.335^{* * *} \\
(0.677)\end{array}$ \\
\hline ECB Mon. Policy Assets & $\begin{array}{l}-8.34 \mathrm{e}-07^{* * *} \\
(1.17 \mathrm{e}-07)\end{array}$ & $\begin{array}{l}-2.85 \mathrm{e}-06^{* * *} \\
(2.43 \mathrm{e}-07)\end{array}$ & $\begin{array}{l}-9.02 \mathrm{e}-06^{* * *} \\
(2.11 \mathrm{e}-06)\end{array}$ & $\begin{array}{l}-6.83 \mathrm{e}-07^{* * *} \\
(1.15 \mathrm{e}-07)\end{array}$ & $\begin{array}{l}-2.83 \mathrm{e}-06^{* * *} \\
(2.42 \mathrm{e}-07)\end{array}$ & $\begin{array}{l}-1.23 e-05^{* * *} \\
(2.05 e-06)\end{array}$ \\
\hline Misvaluation & $\begin{array}{l}4.940 * * * \\
(0.0946)\end{array}$ & $\begin{array}{l}6.517^{* * * *} \\
(0.227)\end{array}$ & $\begin{array}{l}16.59^{* * *} \\
(1.477)\end{array}$ & $\begin{array}{l}4.977^{* * *} \\
(0.0972)\end{array}$ & $\begin{array}{l}6.617^{* * * *} \\
(0.229)\end{array}$ & $\begin{array}{l}16.53 * * * \\
(1.441)\end{array}$ \\
\hline MV (centered) & $\begin{array}{l}1.787^{* * *} \\
(0.0648)\end{array}$ & $\begin{array}{l}6.903^{* * *} \\
(0.148)\end{array}$ & $\begin{array}{l}72.38 * * * \\
(1.298)\end{array}$ & $\begin{array}{l}0.195^{*} \\
(0.100)\end{array}$ & $\begin{array}{l}3.893^{* * *} \\
(0.228)\end{array}$ & $\begin{array}{l}85.08^{* * *} \\
(2.153)\end{array}$ \\
\hline IRBA-S/F & $\begin{array}{l}-5.976^{* * *} \\
(0.735)\end{array}$ & $\begin{array}{l}-11.98^{* * *} \\
(2.082)\end{array}$ & $\begin{array}{l}-91.64^{* * *} \\
(20.14)\end{array}$ & $\begin{array}{l}-10.08^{* * *} \\
(0.751)\end{array}$ & $\begin{array}{l}-17.40^{* * *} \\
(2.099)\end{array}$ & $\begin{array}{l}-40.41^{* *} \\
(20.30)\end{array}$ \\
\hline IRBA-A/M & $\begin{array}{l}4.165^{* * *} \\
(0.746)\end{array}$ & $\begin{array}{l}10.72^{* * *} \\
(2.113)\end{array}$ & $\begin{array}{l}53.28^{* * *} \\
(20.39)\end{array}$ & $\begin{array}{l}0.702 \\
(0.764)\end{array}$ & $\begin{array}{l}4.593^{* *} \\
(2.140)\end{array}$ & $\begin{array}{l}84.18^{* * *} \\
(20.54)\end{array}$ \\
\hline IRBA-S/F \# MV & & & & $\begin{array}{l}3.890 * * * \\
(0.134)\end{array}$ & $\begin{array}{l}4.757^{* * *} \\
(0.305)\end{array}$ & $\begin{array}{l}-51.49 * * * \\
(2.705)\end{array}$ \\
\hline IRBA-A/M \# MV & & & & $\begin{array}{l}-0.256^{*} \\
(0.145)\end{array}$ & $\begin{array}{l}5.648^{* * *} \\
(0.368)\end{array}$ & $\begin{array}{l}50.27^{* * *} \\
(3.946)\end{array}$ \\
\hline Jan 1996- Jun2006 & $\begin{array}{l}-6.040^{* * *} \\
(0.248)\end{array}$ & $\begin{array}{l}-5.139 * * * \\
(0.562)\end{array}$ & $\begin{array}{l}333.9 * * * \\
(6.059)\end{array}$ & $\begin{array}{l}-5.016^{* k *} \\
(0.258)\end{array}$ & $\begin{array}{l}-3.243^{* * *} \\
(0.583)\end{array}$ & $\begin{array}{l}325.4^{* * *} \\
(6.061)\end{array}$ \\
\hline Jun2006- Sep2008 & $\begin{array}{l}-2.539^{* * *} \\
(0.768)\end{array}$ & $\begin{array}{l}1.768 \\
(2.139)\end{array}$ & $\begin{array}{l}339.1^{* * *} \\
(20.84)\end{array}$ & $\begin{array}{l}0.163 \\
(0.781)\end{array}$ & $\begin{array}{l}6.956^{* * *} \\
(2.158)\end{array}$ & $\begin{array}{l}318.2^{* * *} \\
(21.06)\end{array}$ \\
\hline Sep2008- Sep2010 & $\begin{array}{l}-4.291^{* * *} \\
(0.835)\end{array}$ & $\begin{array}{l}-4.609 * * \\
(2.260)\end{array}$ & $\begin{array}{l}304.7^{* * *} \\
(22.12)\end{array}$ & $\begin{array}{l}0.414 \\
(0.857)\end{array}$ & $\begin{array}{l}2.108 \\
(2.299)\end{array}$ & $\begin{array}{l}250.0 * * * \\
(22.36)\end{array}$ \\
\hline Sep2010- Nov2014 & $\begin{array}{l}-5.486^{* * *} \\
(0.822)\end{array}$ & $\begin{array}{l}-7.119 * * * \\
(2.232)\end{array}$ & $\begin{array}{l}303.8^{* * *} \\
(21.78)\end{array}$ & $\begin{array}{l}-0.633 \\
(0.848)\end{array}$ & $\begin{array}{l}0.137 \\
(2.276)\end{array}$ & $\begin{array}{l}250.0 * * * \\
(22.05)\end{array}$ \\
\hline Nov2014- Dec2018 & $\begin{array}{l}-6.081^{* * *} \\
(0.841)\end{array}$ & $\begin{array}{l}-3.534 \\
(2.266)\end{array}$ & $\begin{array}{l}337.7^{* * *} \\
(22.06)\end{array}$ & $\begin{array}{l}-1.298 \\
(0.865)\end{array}$ & $\begin{array}{l}3.589 \\
(2.310)\end{array}$ & $\begin{array}{l}284.4^{* * *} \\
(22.31)\end{array}$ \\
\hline Country effects & $\begin{array}{l}\text { yes } \\
(0.278)\end{array}$ & $\begin{array}{l}\text { yes } \\
(0.880)\end{array}$ & $\begin{array}{l}\text { yes } \\
(13.63)\end{array}$ & $\begin{array}{l}\text { yes } \\
(0.282)\end{array}$ & $\begin{array}{l}\text { yes } \\
(0.881)\end{array}$ & $\begin{array}{l}\text { yes } \\
(13.51)\end{array}$ \\
\hline Constant & $\begin{array}{l}-8.361^{* * *} \\
(0.410)\end{array}$ & $\begin{array}{l}-7.653^{* * *} \\
(0.855)\end{array}$ & $\begin{array}{l}-312.0 * * * \\
(8.253)\end{array}$ & $\begin{array}{l}-9.770 * * * \\
(0.420)\end{array}$ & $\begin{array}{l}-10.66^{* * *} \\
(0.888)\end{array}$ & $\begin{array}{l}-303.5^{* * *} \\
(8.378)\end{array}$ \\
\hline Observations & 98,211 & 98,211 & 98,211 & 98,211 & 98,211 & 98,211 \\
\hline Number of banks & 99 & 99 & 99 & 99 & 99 & 99 \\
\hline R-squared & 0.387 & 0.535 & 0.625 & 0.395 & 0.537 & 0.629 \\
\hline RMSE & 14.85 & 32.70 & 300.4 & 14.75 & 32.64 & 298.5 \\
\hline Percentile & 2.83 & 17.15 & 103.07 & 2.83 & 17.15 & 103.07 \\
\hline Norm.RMSE & 5.245 & 1.907 & 2.914 & 5.210 & 1.903 & 2.896 \\
\hline
\end{tabular}

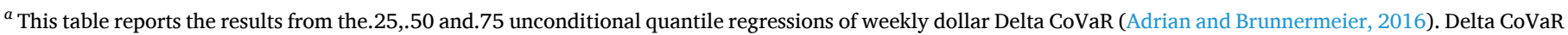

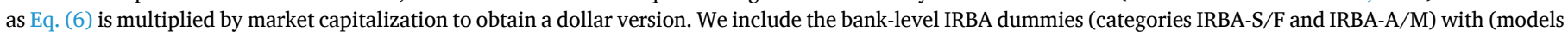

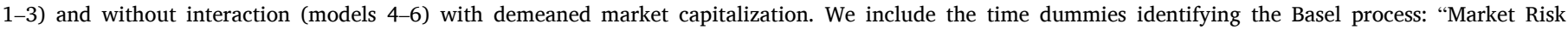

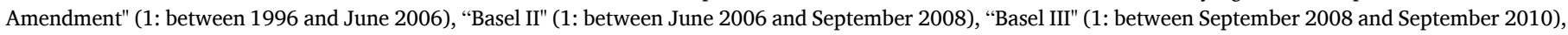

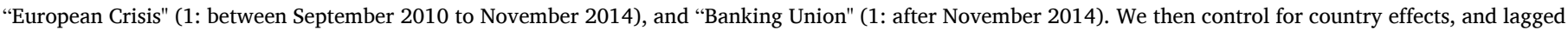

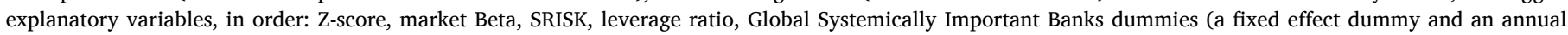

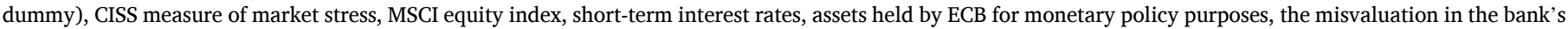
equity as (Rhodes-Kropf et al., 2005), and the demeaned market capitalization. Robust standard errors in parentheses. ${ }^{* * *} \mathrm{p}<0.01,{ }^{* *} \mathrm{p}<0.05$, ${ }^{*} \mathrm{p}<0.1$.

\section{References}

A. Crockett, 2000. Marrying the Micro- and Macro-prudential Dimensions of Financial Stability, BIS Review 76, Bank of International Settlement, BASEL.

Acharya, V., Engle, R., Richardson, M., 2012. Capital shortfall: a new approach to ranking and regulating systemic risks. Am. Econ. Rev. Pap. Proc. 102 (3), 59-64.

Acharya, V., Engle, R., Pierret, D., 2014. Testing macroprudential stress tests: the risk of regulatory risk weights. J. Monet. Econ. 65, 36-53.

Admati, A., Hellwig, M., 2013. The Bankers' New Clothes. Princeton University Press, Princeton.

Admati, A., DeMarzo, P., Hellwig, M., Pfleiderer, P., 2018. The leverage ratchet effect. J. Financ. 73 (1), 145-198.
Adrian, T., Brunnermeier, M.K., 2016. CoVaR. Am. Econ. Rev. 106 (7), 1705-1741.

Arnold, M., 2018. Banking Leverage Remains Dangerously High, Warns Vickers in Swipe at Financial Regulators. Financial Times, 2 May 2018.

Baron, M., W. Xiong , 2014. Credit Expansion and Neglected Crash Risk, working paper, Princeton.

Barth, J.R., Caprio Jr., G., Levine, R. (2013): Bank Regulation and Supervision in 180Countries from 1999 to 2011. NBER Working Paper No. 18733.

Basel Committee on Banking Supervision, 1988. International Convergence of Capital Measurement and Capital Standards. Basel. July 1988.

Basel Committee on Banking Supervision, 1996. Amendment to the Capital Accord to Incorporate Market Risks. Basel. January 1996.

Basel Committee on Banking Supervision, 2014. The G-SIB Assessment Methodology Score calculation. Basel. November 2014. 
Basel Committee on Banking Supervision, 2016. Consultative Document - Reducing variation in credit risk-weighted assets: constraints on the use of internal model approaches. Basel. March 2016.

Behn, M., R. Haselmann, V. Vig (2016b): The Limits of Model-Based Regulation, ECB Working Paper No. 1928, Frankfurt, July 2016.

Behn, M., Haselmann, R., Wachtel, P., 2016a. Procyclical Capital Regulation and Lending. J. Financ. 71 (2), 919-956.

Beltratti, A., Stulz, R.M., 2012. The credit crisis around the globe: why did some banksperform better? J. Financ. Econ. 105, 1-17.

Benoit, S. (2018): Smart Systemic Risk Scores, mimeo.

Benoit, S., Hurlin, C., Perignon, C., 2019. Pitfalls in systemic-risk scoring. J. Financ. Intermediation 38, 19-44.

Boot, A., Ratnovski, L., 2016. Banking and trading. Rev. Financ. 20 (6), 2219-2246.

Bostandzic, D., Weiss, G., 2018. Why do some banks contribute more to global systemic risk? J. Financ. Intermediation 35, 17-40.

Boyd, J.H., Runkle, D.E., 1993. Size and performance of banking firms: testing the predictions of theory. J. Monet. Econ. 31 (1), 47-67.

Brownlees, D., Engle, R.F., 2017. SRISK: a conditional capital shortfall measure of systemic risk. Rev. Financ. Stud. 30 (1), 48-79.

C. Borio, C. Furfine, P. Lowe. 2001. Pro-cyclicality of the financial system and financial stability:Issues and policy options, Working paper, Bank for International Settlements.

Colletaz, G., Levieuge, G., Popescu, A., 2018. Monetary policy and long-run systemic risk taking. J. Econ. Dyn. Control 86, 165-184.

Colliard, J.-E., 2015. Strategic Selection of Risk Models and Bank Capital Regulation, working paper.

Daesik, Kim, Santomero, Anthony, 1988. Risk in banking and capital regulation. J. Financ. 43, 1219-1233.

Daniel, K., Titman, S., 2006. Market reactions to tangible and intangible information. J. Financ. 61/4, 1605-1643.

Danielson, J., Embrechts, P., Goodhart, C., Keating, C., Münnich, F., Renault, O., Shin, H. S., 2001. An academic response to basel II. FMG Spec. Pap. 130.

Engle, R.F., 2002. Dynamic conditional correlation: a simple class of multivariate generalized autoregressive conditional heteroskedasticity models. J. Bus. Econ. Stat. 20, 339-350.

Engle, R.F., Jondeau, E., Rockinger, M., 2015. Systemic risk in Europe. Rev. Financ. 19 (1), 145-190.

Fiordelisi, F., Marques-Ibanez, D., 2013. Is bank default risk systematic? J. Bank. Financ. 37 (6), 2000-2010.

Firpo, S., Fontin, N., Lemieux, T., 2009. Unconditional quantile regressions. Econometrica 37 (6), 2000-2010.

Freixas, X., Laeven, L., Peydro, J.L., 2015. Systemic Risk, Crises and Macroprudential Policy. MIT-Press, Boston.

Gehrig, T., 1995. Capital adequacy rules: implications for banks' risk taking. Swiss J. Econ. Stat. 131 (4/2), 747-764.

Gehrig, T., 1996. Market structure, monitoring and capital adequacy regulation. Swiss J. Econ. Stat. 132 (4/2), 685-702.

Gehrig, T., Iannino, M.C., 2018. Bank capital regulation and systemic risk in the insurance sector. J. Financ. Econ. Policy 11 (2), 237-263.
Giglio, S., Kelly, B., Pruitt, S., 2016. Systemic risk and the macroeconomy: an empirical evaluation. J. Financ. Econ. 119 (3), 457-471.

Glosten, L., Jagananthan, R., Runkle, D., 1993. On the relation between the expected value and the volatility of nominal excess returns on stocks. J. Financ. 48 (5), 1779-1801.

Goodhart, C., 2011. The Basle Committee of Banking Supervision: A History of the Early Years 1974-1997. Cambridge University Press, p. 2011.

Hakenes, H., Schnabel, I., 2011. Bank size and risk taking under basel II. J. Bank. Financ. 35, 1436-1449.

Hellwig, M., 1995. Systemic aspects of risk management in banking and finance. Swiss J. Econ. Stat. 131 (4/2), 723-737.

Hellwig, M., 2009. Systemic risk in the financial sector: an analysis of the subprime mortgage financial crisis. De Econ. 157, 129-207.

Hellwig, M. , 2010. Capital Regulation after the Crisis: Business as Usual?, Preprints of the Max-Planck Institute for Research on Collective Goods 2010/31.

Holló, D., Kremer, M., LoDuca, M., 2012. A Composite Indicator of Systemic Stress in the Financial System. ECB Working Paper Series, March, no. 1426, p. 1-51.

Homar, T., Kick, H., Salleo, C., 2016. Making sense of the EU wide stress test: comparing with the SRISK approach. ECB Work. Pap. 1920.

Hovakimian, A., E. Kane, L. Laeven , 2012. Variation in Systemic Risk at US Banks During 1974-2013, NBER Working Paper No. 18043.

Kahane, Y., 1977. Capital adequacy and the regulation of financial intermediaries. J Bank Financ 1 (2), 207-218.

Kuls, N., 2018. Amerikas Banken sind m"achtiger denn je, Frankfurter Allgemeine Zeitung, 13. Sept. 2018.

Laeven, L., Levine, R., 2009. Bank governance, regulation, and risk taking. J. Financ. Econ. 93, 259-275.

Mariathasan, M., Merrouche, O., 2014. The manipulation of Basel risk weights. J. Financ. Intermediation 23 (3), 300-321.

Michael, Koehn, Santomero, Anthony, 1980. Regulation of bank capital and portfolio risk. J. Financ. 35, 1235-1244.

Miles, D., Yang, J., Marcheggiano, G., 2012. Optimal bank capital. Econ. J. 123, 1-37.

Ongena, S., Popov, A., Udell, G.F., 2013. When the cat's away the mice will play: does regulation at home affect bank risk-taking abroad? J. Financ. Econ. 108, 727-750.

Rafael, Repullo, Suarez, Javier, 2012. The procyclical effects of bank capital regulation. Rev. Financ. Stud. 26, 452-490.

Rhodes-Kropf, M., Robinson, D.T., Viswanathan, S., 2005. Valuation waves and merger activity. The empirical evidence. J. Financ. Econ. 77 (3), 561-603.

Rochet, J.C., 1992. Capital requirements and the behaviour of commercial banks. Eur. Econ. Rev. 36 (5), 1137-1170.

Rosenbaum, P.R., Rubin, D.B., 1983. The central role of the propensity score in observational studies for causal effects. Biometrika 70 (1), 41-55.

Vickers, J. , 2017. Response to the Treasury Select Committeeas Capital Inquiry: Recovery and Resolution, Oxford, 3 March 2017.

Wagner, W., 2010. Diversification at financial institutions and systemic crises. J. Financ. Inter. 19, 373-386.

Wagster, J., 1996. Impact of the 1988 basle accord on international banks. J. Financ. 52 (4), 1321-1346.

Wuffli, P., 1995. Comment on the paper by Professor Hellwig: systemic aspects of risk management in banking and finance. Swiss J. Econ. Stat. 131 (4/2), 739-740. 